\title{
Cadinane-Type Sesquiterpenoids with Cytotoxic Activity from the Infected Stems of the Semi-mangrove Hibiscus tiliaceus
}

De-Li Chen, ${ }^{\dagger},+$ Mei-Ying Chen,$^{\dagger}$ Yong Hou,$^{\dagger}$ Can-Hong Wang, ${ }^{\dagger}$ Zhao-Cui Sun, ${ }^{\dagger}$

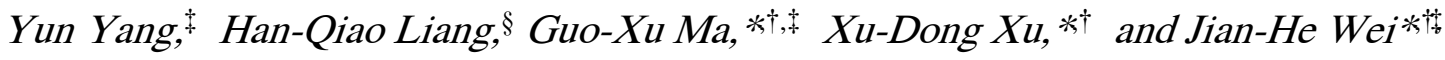

$\dagger$ Institute of Medicinal Plant Development, Chinese Academy of Medical Sciences \&

Peking Union Medical College, Haidian District, Beijing 100193, People's Republic

of China

*Hainan Branch Institute of Medicinal Plant Development (Hainan Provincial Key Laboratory of Resources Conservation and Development of Southern Medicine), Chinese Academy of Medical Sciences \& Peking Union Medical College, Haikou 570311, People's Republic of China

$\S$ Department of Biomedicine, Beijing City University, Beijing 100083, People's Republic of China

* Corresponding Authors. Email addresses: mgxfl8785@163.com; xdxu@implad.ac.cn; wjianh@263.net 
ABSTRACT: Eight new cadinane sesquiterpenoids (1-8), along with two known compounds 9 and 10, were isolated from infected stems of the semi-mangrove plant, Hibiscus tiliaceus. The structures of compounds 1-8 were elucidated through the analysis of their 1D and 2D NMR and MS data, and their absolute configurations were determined by comparing their experimental and calculated ECD spectra and by single-crystal X-ray diffraction. The two confused known compounds (9 and 10), were resolved using single-crystal X-ray crystallography. Compounds 1-3 have novel norsesquiterpene carbon skeletons arising from a ring contraction rearrangement. All obtained isolates evaluated against the HepG2 and Huh7 cell lines, and compounds $\mathbf{1 b}$, 2b, 4, 6 and 8 showed cytotoxic activity toward both cell lines, with $\mathrm{IC}_{50}$ values ranging from 3.5 to $6.8 \mu \mathrm{M}$. 


\section{List of Figures S1-S74}

Figure S1. Experimental and calculated ECD spectra of compounds 1-3

Figure S2. ${ }^{1} \mathrm{H}$ NMR $\left(600 \mathrm{MHz}, \mathrm{CDCl}_{3}\right)$ spectrum of the new compound 1

Figure S3. ${ }^{13} \mathrm{C}$ APT $\left(150 \mathrm{MHz}, \mathrm{CDCl}_{3}\right)$ spectrum of the new compound $\mathbf{1}$

Figure S4. HSQC spectrum of the new compound 1

Figure S5. HMBC spectrum of the new compound 1

Figure S6. ${ }^{1} \mathrm{H}-{ }^{1} \mathrm{H}$ COSY spectrum of the new compound 1

Figure S7. ROESY spectrum of the new compound 1

Figure S8. Positive ion HRESIMS of 1

Figure S9. Chiral HPLC analysis of compound 1

Figure $\mathrm{S} 10 .{ }^{1} \mathrm{H} \mathrm{NMR}\left(600 \mathrm{MHz}, \mathrm{CDCl}_{3}\right)$ spectrum of the new compound 2

Figure $\mathrm{S} 11 .{ }^{13} \mathrm{C}$ APT $\left(150 \mathrm{MHz}, \mathrm{CDCl}_{3}\right)$ spectrum of the new compound 2

Figure S12. HSQC spectrum of the new compound 2

Figure S13. HMBC spectrum of the new compound 2

Figure S14. ${ }^{1} \mathrm{H}-{ }^{1} \mathrm{H}$ COSY spectrum of the new compound 2

Figure S15. ROESY spectrum of the new compound $\mathbf{2}$

Figure S16. Positive ion HRESIMS of 2

Figure S17. Chiral HPLC analysis of compound 2

Figure S18. ${ }^{1} \mathrm{H}$ NMR $\left(600 \mathrm{MHz}, \mathrm{CDCl}_{3}\right)$ spectrum of the new compound 3

Figure $\mathrm{S} 19 .{ }^{13} \mathrm{C}$ APT $\left(150 \mathrm{MHz}, \mathrm{CDCl}_{3}\right)$ spectrum of the new compound 3

Figure S20. HSQC spectrum of the new compound $\mathbf{3}$

Figure S21. HMBC spectrum of the new compound $\mathbf{3}$

Figure S22. ${ }^{1} \mathrm{H}-{ }^{1} \mathrm{H}$ COSY spectrum of the new compound $\mathbf{3}$

Figure S23. ROESY spectrum of the new compound $\mathbf{3}$

Figure S24. Positive ion HRESIMS of 3

Figure S25. Chiral HPLC analysis of compound $\mathbf{3}$ 
Figure S26. ${ }^{1} \mathrm{H} \mathrm{NMR}\left(600 \mathrm{MHz}, \mathrm{CDCl}_{3}\right)$ spectrum of the new compound 4

Figure $\mathrm{S} 27 .{ }^{13} \mathrm{C}$ APT $\left(150 \mathrm{MHz}, \mathrm{CDCl}_{3}\right)$ spectrum of the new compound 4 Figure S28. HSQC spectrum of the new compound 4

Figure S29. HMBC spectrum of the new compound 4

Figure S30. ${ }^{1} \mathrm{H}-{ }^{1} \mathrm{H}$ COSY spectrum of the new compound 4

Figure S31. ROESY spectrum of the new compound 4

Figure S32. Positive ion HRESIMS of 4

Figure S33. ${ }^{1} \mathrm{H}$ NMR $\left(600 \mathrm{MHz}, \mathrm{CDCl}_{3}\right)$ spectrum of the new compound $\mathbf{5}$

Figure S34. ${ }^{13} \mathrm{C}$ APT $\left(150 \mathrm{MHz}, \mathrm{CDCl}_{3}\right)$ spectrum of the new compound 5

Figure S35. HSQC spectrum of the new compound 5

Figure S36. HMBC spectrum of the new compound $\mathbf{5}$

Figure S37. ${ }^{1} \mathrm{H}-{ }^{1} \mathrm{H}$ COSY spectrum of the new compound $\mathbf{5}$

Figure S38. ROESY spectrum of the new compound $\mathbf{5}$

Figure S39. Positive ion HRESIMS of 5

Figure $\mathrm{S} 40 .{ }^{1} \mathrm{H} \mathrm{NMR}\left(600 \mathrm{MHz}, \mathrm{CDCl}_{3}\right)$ spectrum of the new compound 6

Figure $\mathrm{S} 41 .{ }^{13} \mathrm{C}$ APT $\left(150 \mathrm{MHz}, \mathrm{CDCl}_{3}\right)$ spectrum of the new compound 6

Figure S42. HSQC spectrum of the new compound 6

Figure S43. HMBC spectrum of the new compound 6

Figure S44. ${ }^{1} \mathrm{H}-{ }^{1} \mathrm{H}$ COSY spectrum of the new compound 6

Figure S45. ROESY spectrum of the new compound 6

Figure S46. Positive ion HRESIMS of 6

Figure $\mathrm{S} 47 .{ }^{1} \mathrm{H} \mathrm{NMR}\left(600 \mathrm{MHz}, \mathrm{CDCl}_{3}\right)$ spectrum of the new compound 7

Figure $\mathrm{S} 48 .{ }^{13} \mathrm{C}$ APT $\left(150 \mathrm{MHz}, \mathrm{CDCl}_{3}\right)$ spectrum of the new compound 7

Figure S49. HSQC spectrum of the new compound 7

Figure S50. HMBC spectrum of the new compound 7

Figure S51. ${ }^{1} \mathrm{H}-{ }^{1} \mathrm{H}$ COSY spectrum of the new compound 7

Figure S52. ROESY spectrum of the new compound 7 
Figure S53. Positive ion HRESIMS of 7

Figure S54. ${ }^{1} \mathrm{H}$ NMR $\left(600 \mathrm{MHz}, \mathrm{CDCl}_{3}\right)$ spectrum of the new compound $\mathbf{8}$

Figure S55. ${ }^{13} \mathrm{C}$ APT $\left(150 \mathrm{MHz}, \mathrm{CDCl}_{3}\right)$ spectrum of the new compound 8

Figure S56. HSQC spectrum of the new compound $\mathbf{8}$

Figure S57. HMBC spectrum of the new compound $\mathbf{8}$

Figure S58. ${ }^{1} \mathrm{H}-{ }^{1} \mathrm{H}$ COSY spectrum of the new compound 8

Figure S59. ROESY spectrum of the new compound $\mathbf{8}$

Figure S60. Positive ion HRESIMS of 8

Figure S61. ${ }^{1} \mathrm{H}-\mathrm{NMR}\left(600 \mathrm{MHz}, \mathrm{CDCl}_{3}\right)$ spectrum of the new compound 9

Figure S62. ${ }^{13} \mathrm{C}$ APT $\left(150 \mathrm{MHz}, \mathrm{CDCl}_{3}\right)$ spectrum of the new compound 9

Figure S63. HSQC spectrum of the new compound 9

Figure S64. HMBC spectrum of the new compound 9

Figure S65. ${ }^{1} \mathrm{H}-{ }^{1} \mathrm{H}$ COSY spectrum of the new compound 9

Figure S66. ROESY spectrum of the new compound 9

Figure S67. Positive ion HRESIMS of 9

Figure S68. ${ }^{1} \mathrm{H}$ NMR $\left(600 \mathrm{MHz}, \mathrm{CDCl}_{3}\right)$ spectrum of the new compound 10

Figure $\mathrm{S} 69 .{ }^{13} \mathrm{C}$ APT $\left(150 \mathrm{MHz}, \mathrm{CDCl}_{3}\right)$ spectrum of the new compound $\mathbf{1 0}$

Figure S70. HSQC spectrum of the new compound $\mathbf{1 0}$

Figure S71. HMBC spectrum of the new compound $\mathbf{1 0}$

Figure S72. ${ }^{1} \mathrm{H}-{ }^{1} \mathrm{H}$ COSY spectrum of the new compound $\mathbf{1 0}$

Figure S73. NOESY spectrum of the new compound 10

Figure S74. Positive ion HRESIMS of $\mathbf{1 0}$ 

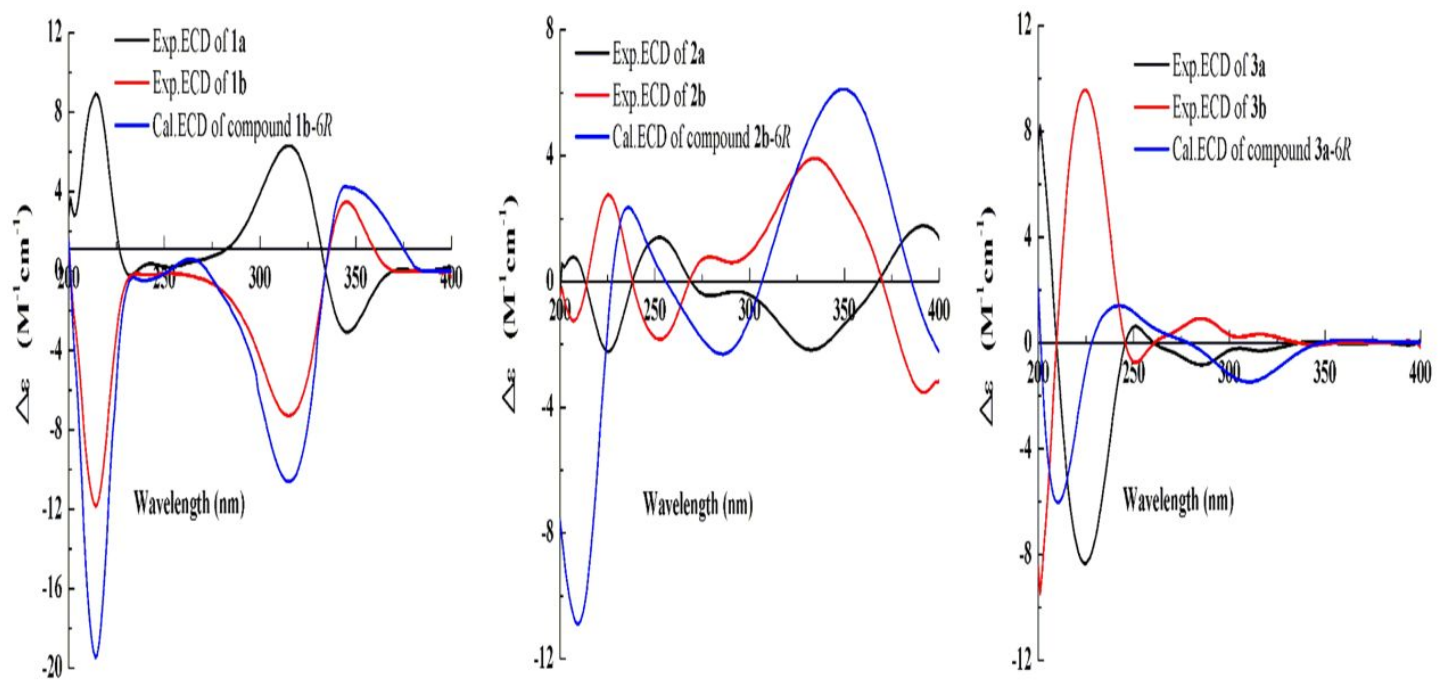

Figure S1. Experimental and calculated ECD spectra of compounds 1-3

$\begin{array}{ll}\text { बू. } & 0 \\ \stackrel{\mid}{\mid} & \stackrel{1}{\mid}\end{array}$

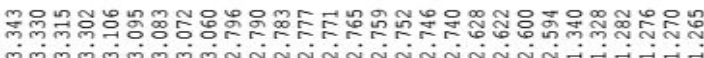

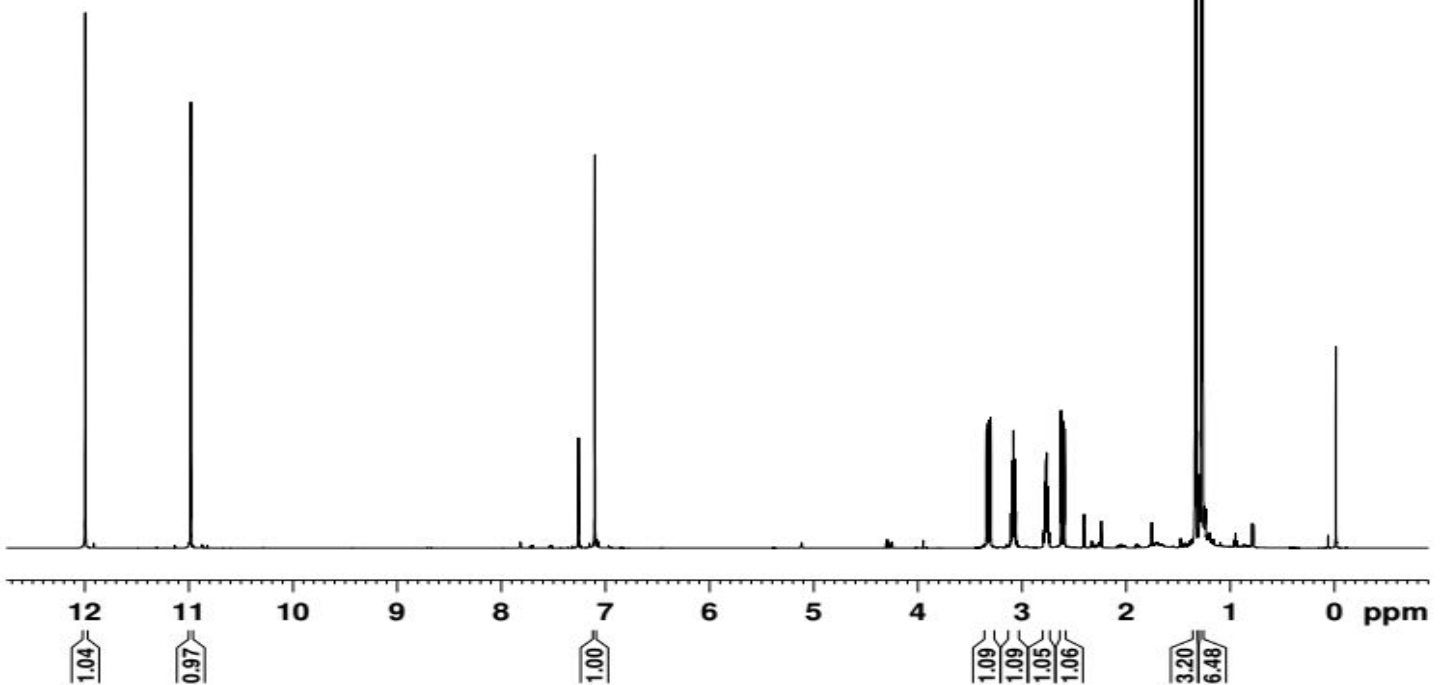

Figure S2. ${ }^{1} \mathrm{H}$ NMR $\left(600 \mathrm{MHz}, \mathrm{CDCl}_{3}\right)$ spectrum of the new compound 1 


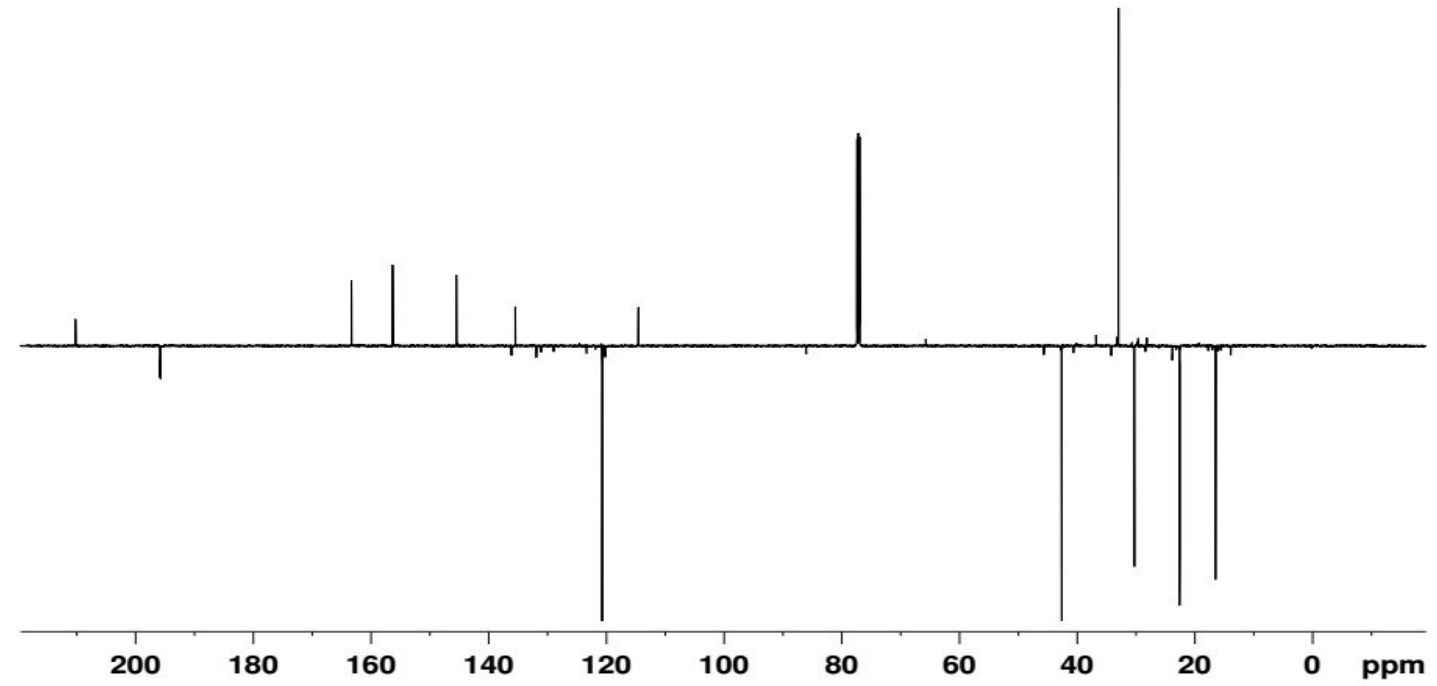

Figure S3. ${ }^{13} \mathrm{C}$ APT $\left(150 \mathrm{MHz}, \mathrm{CDCl}_{3}\right)$ spectrum of the new compound 1

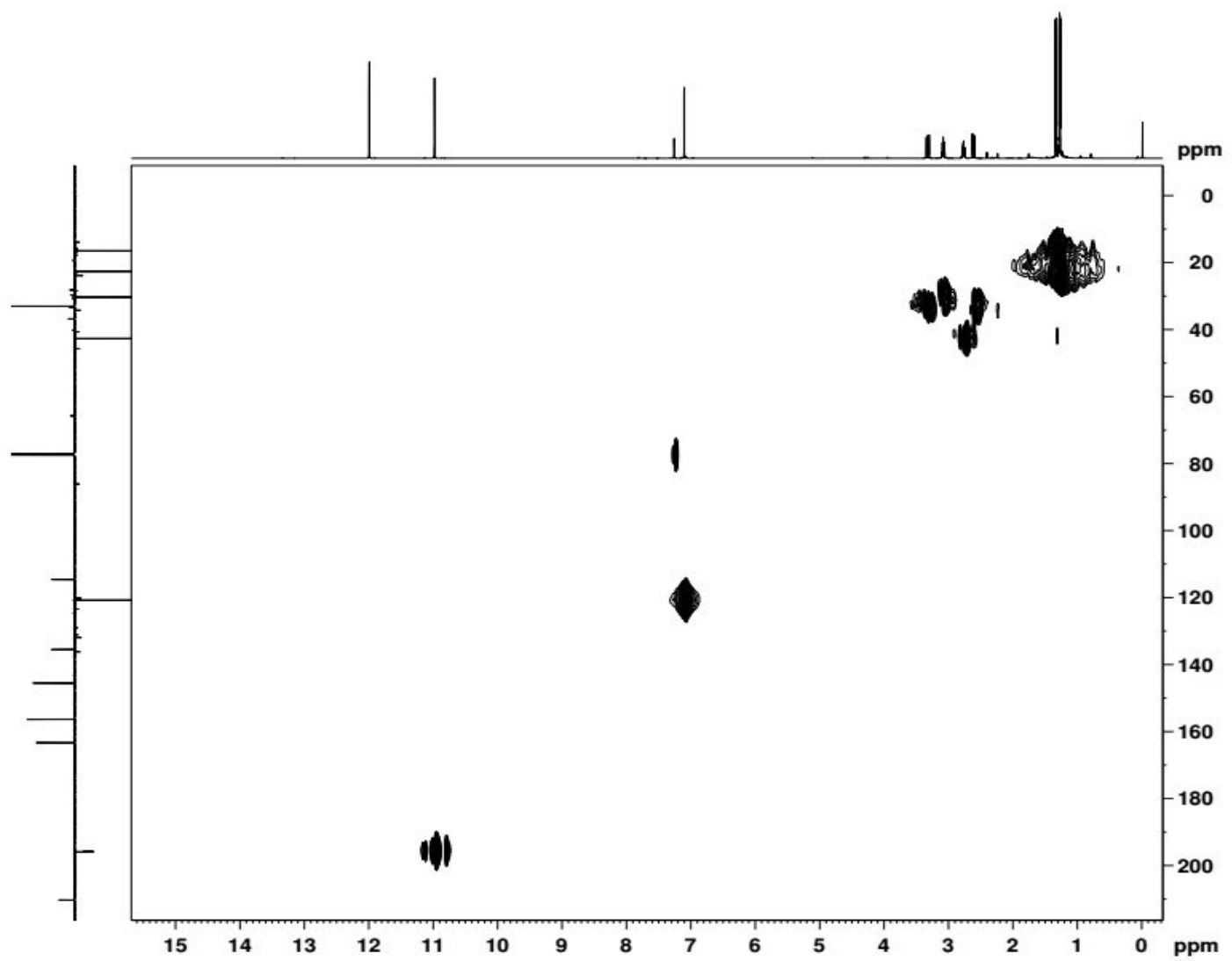

Figure S4. HSQC spectrum of the new compound 1 


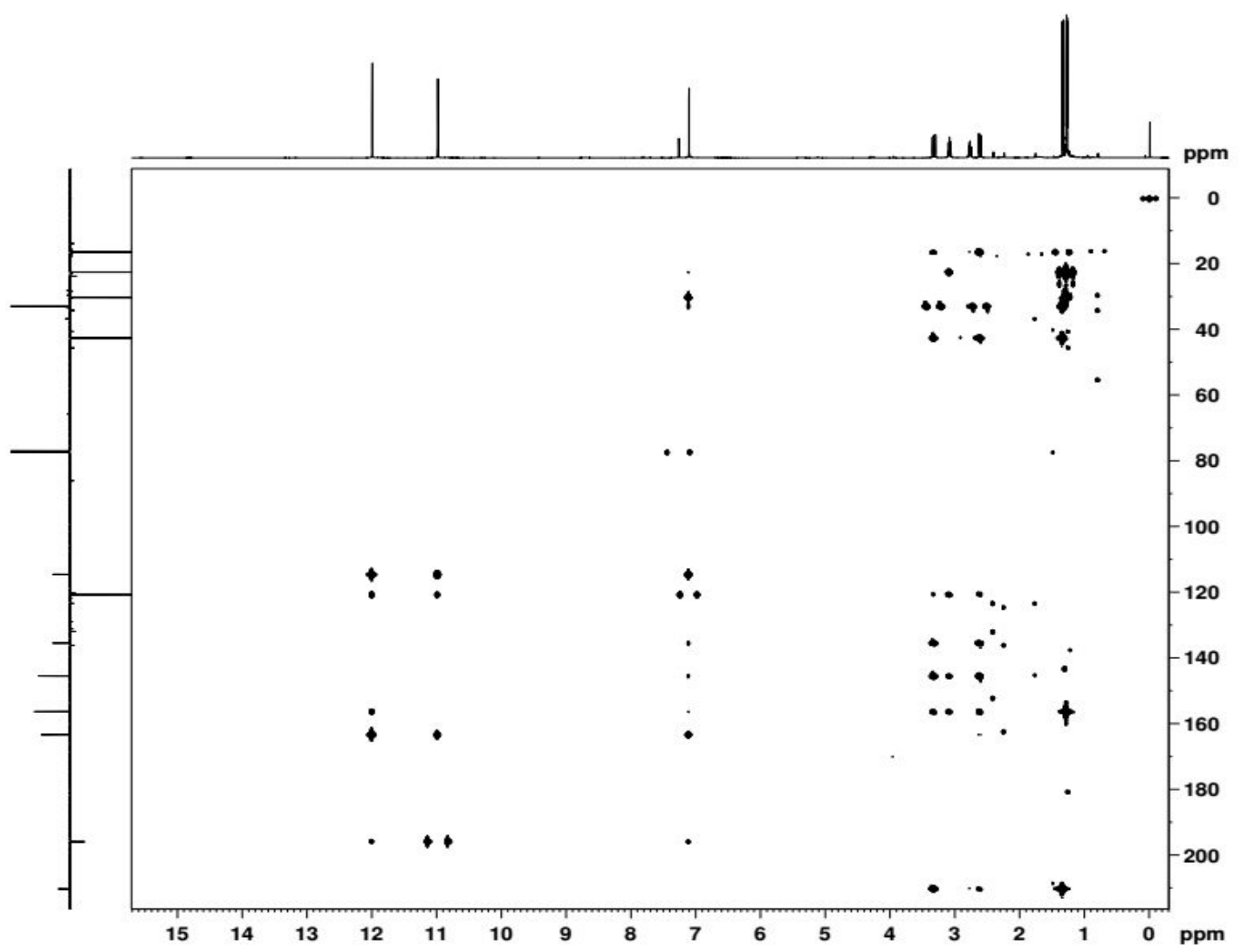

Figure S5. HMBC spectrum of the new compound 1

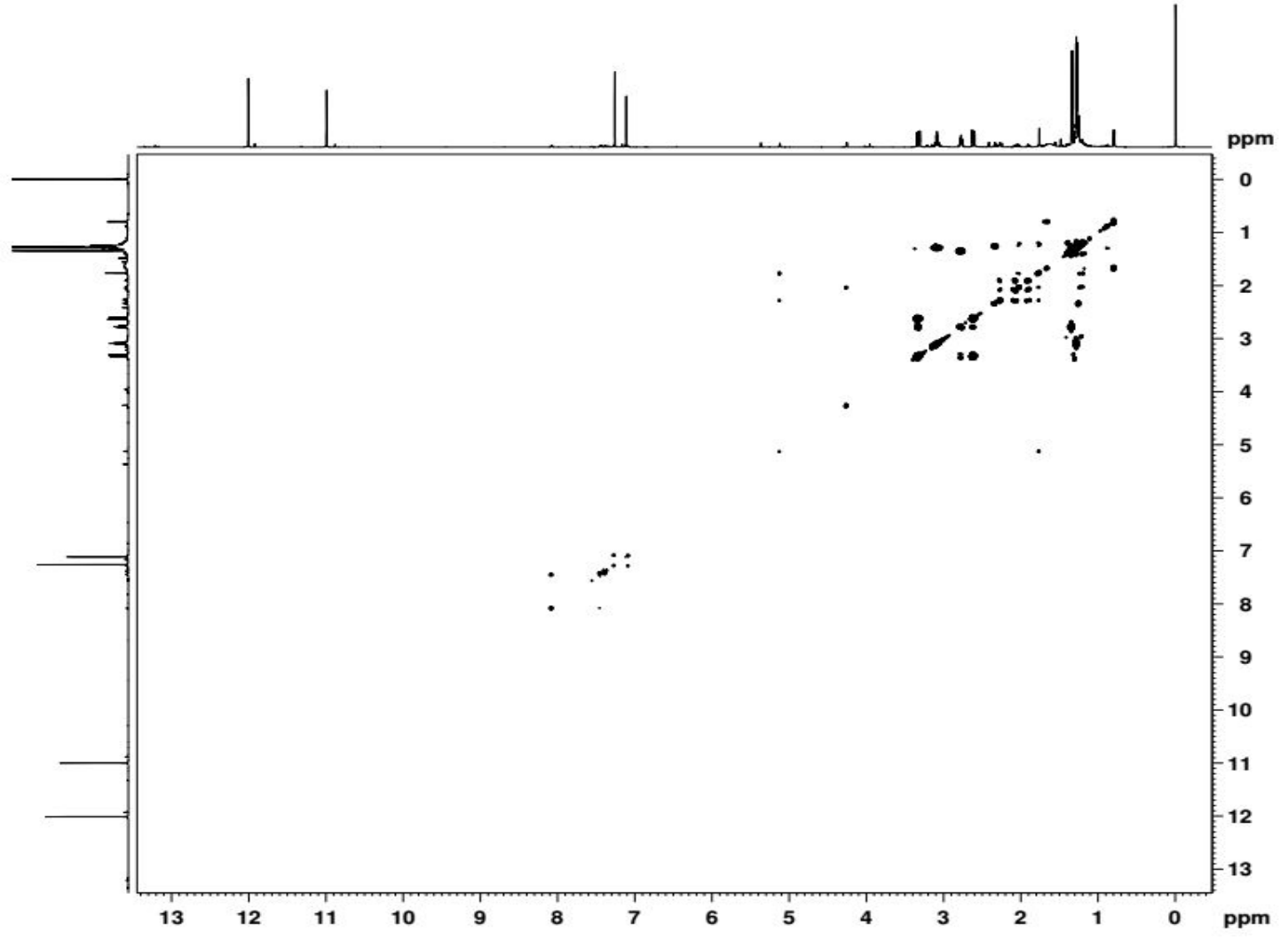

Figure S6. ${ }^{1} \mathrm{H}-{ }^{1} \mathrm{H}$ COSY spectrum of the new compound 1 


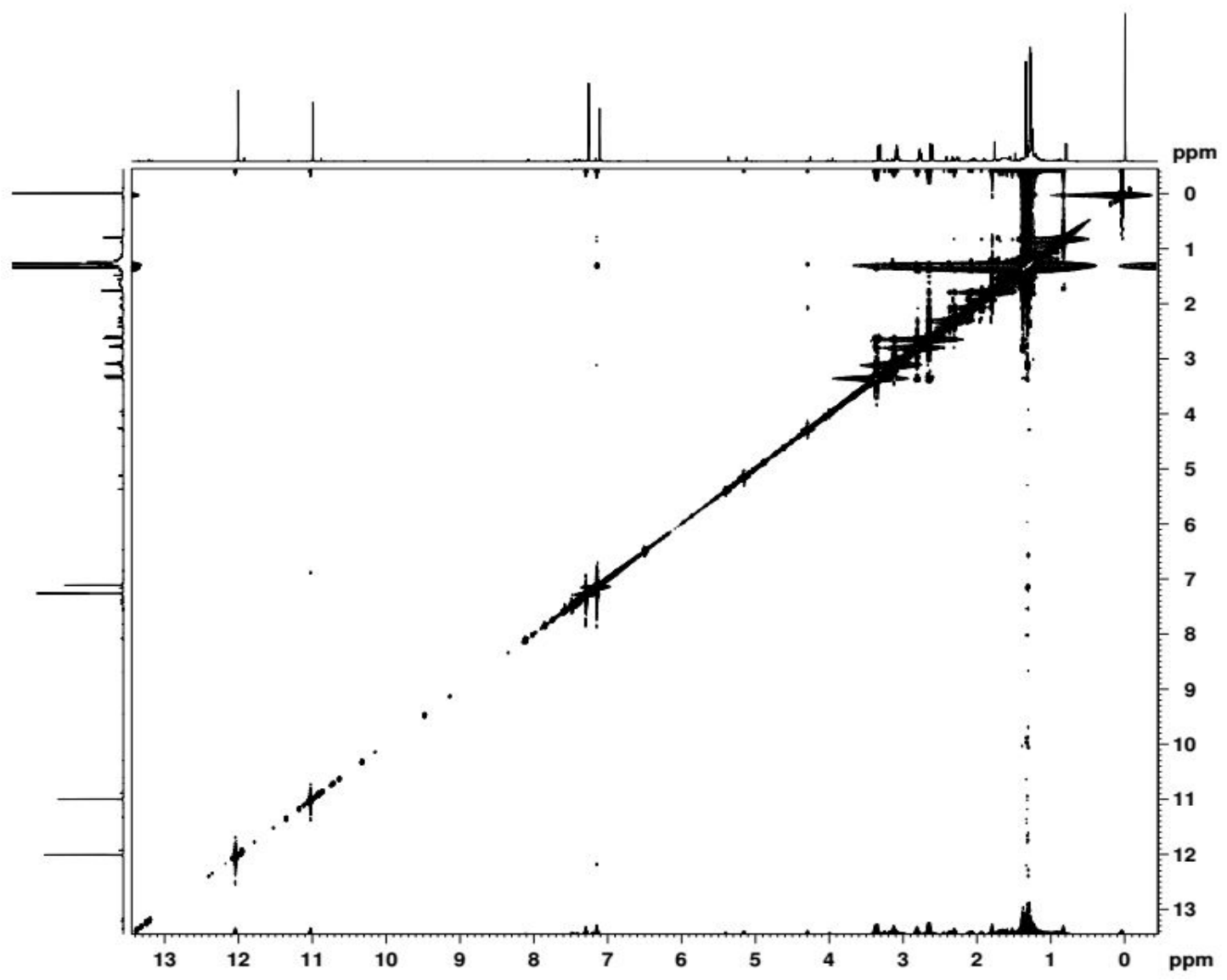

Figure S7. ROESY spectrum of the new compound 1

HJXC-23-6-1

HJXC-23-6-1 432 (8.392)

100

233.1176

1: TOF MS ES+

$1.22 \mathrm{e}$

231.1033

$\%$

249.1138

219.1029

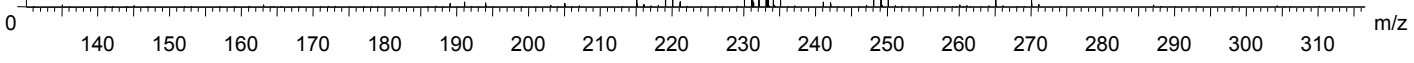

Figure S8. Positive ion HRESIMS of 1 


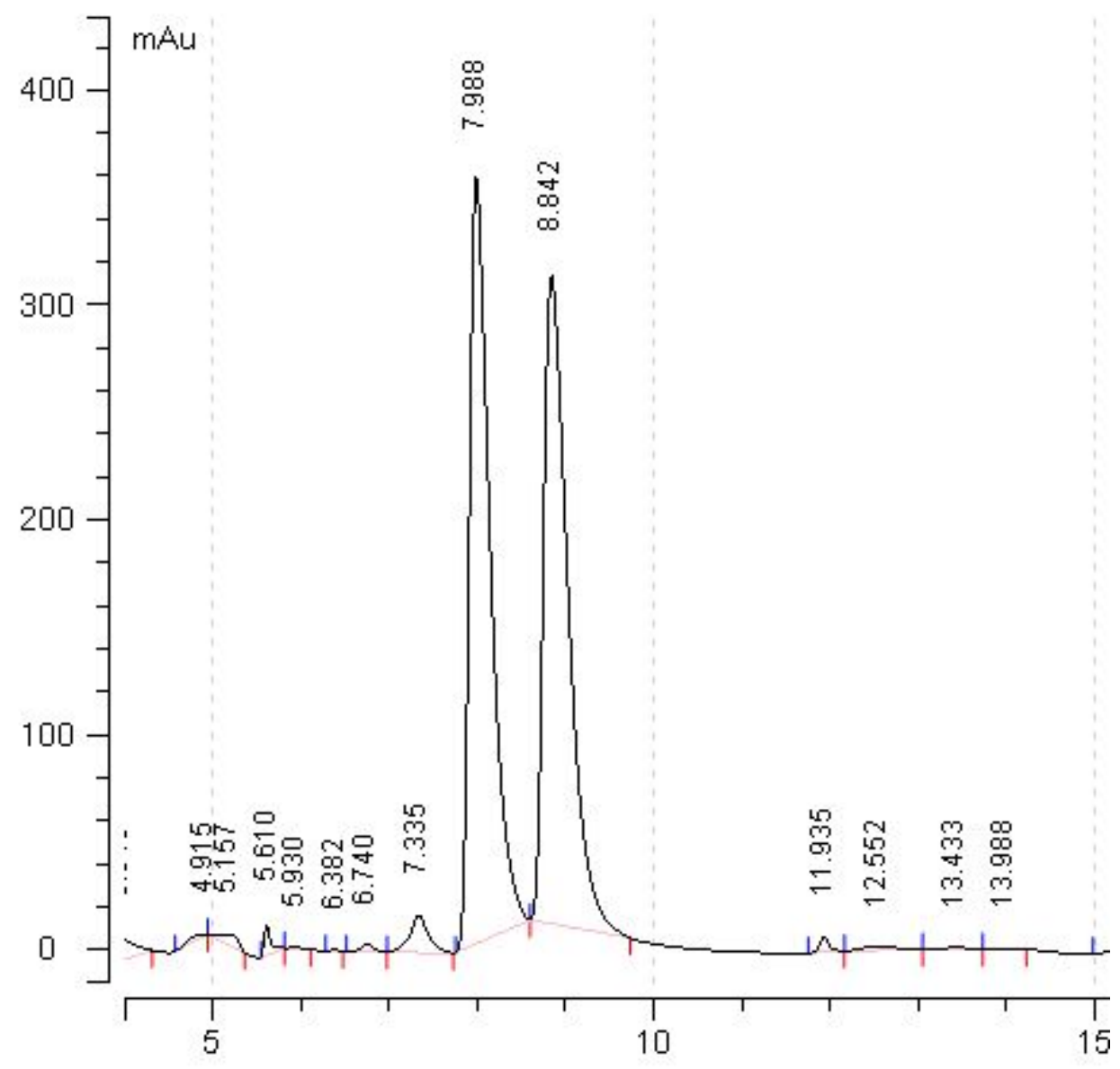

Figure S9. Chiral HPLC analysis of compound 1 (Daicel CHIRALPAK AB-N-5 column, $\mathrm{n}-\mathrm{Hexane} / \mathrm{IPA}=98 / 2,1.0 \mathrm{~mL} / \mathrm{min}$ ) 

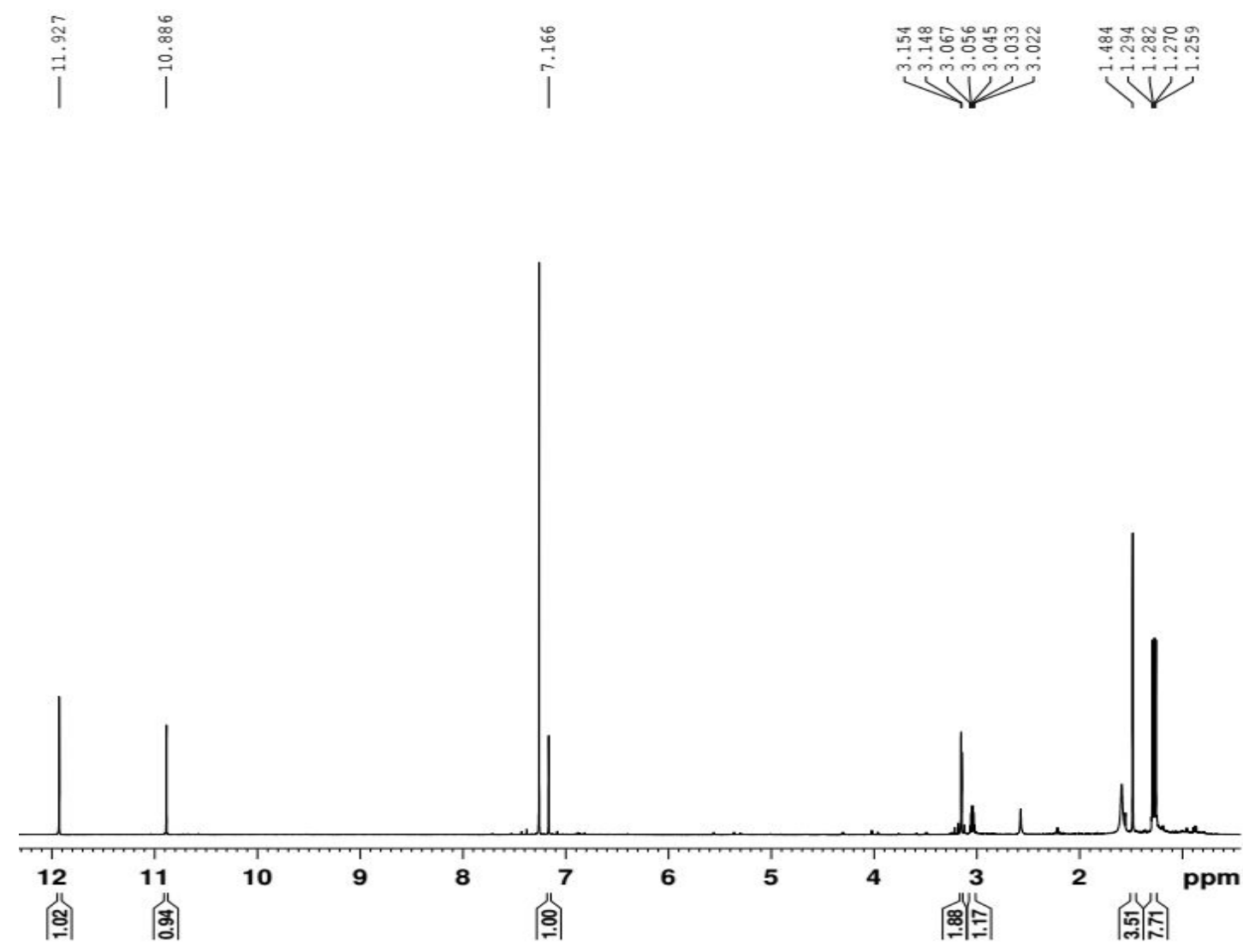

Figure S10. ${ }^{1} \mathrm{H} \mathrm{NMR}\left(600 \mathrm{MHz}, \mathrm{CDCl}_{3}\right)$ spectrum of the new compound 2

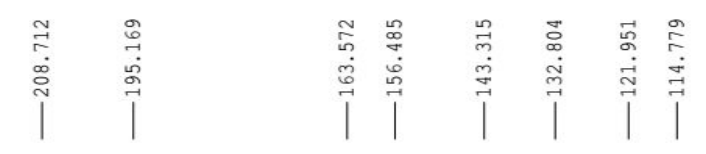

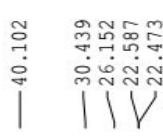

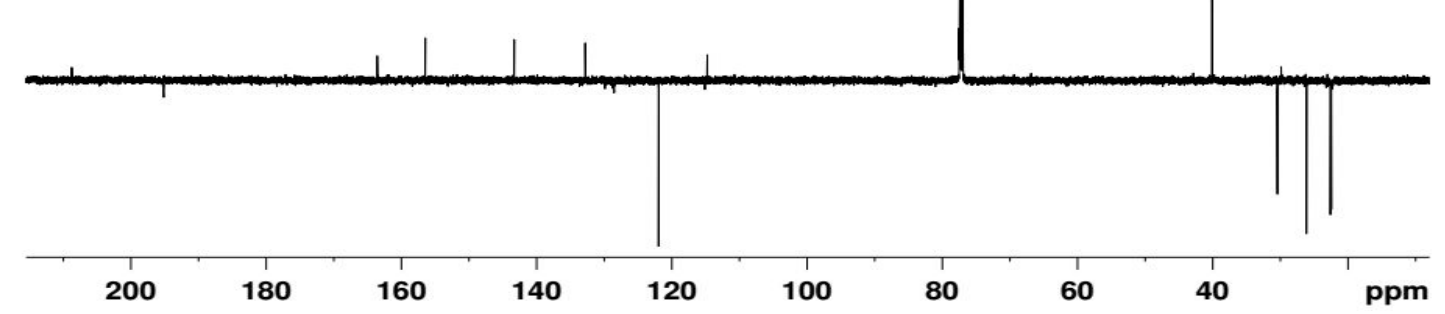

Figure $\mathrm{S} 11 .{ }^{13} \mathrm{C}$ APT $\left(150 \mathrm{MHz}, \mathrm{CDCl}_{3}\right)$ spectrum of the new compound 2 


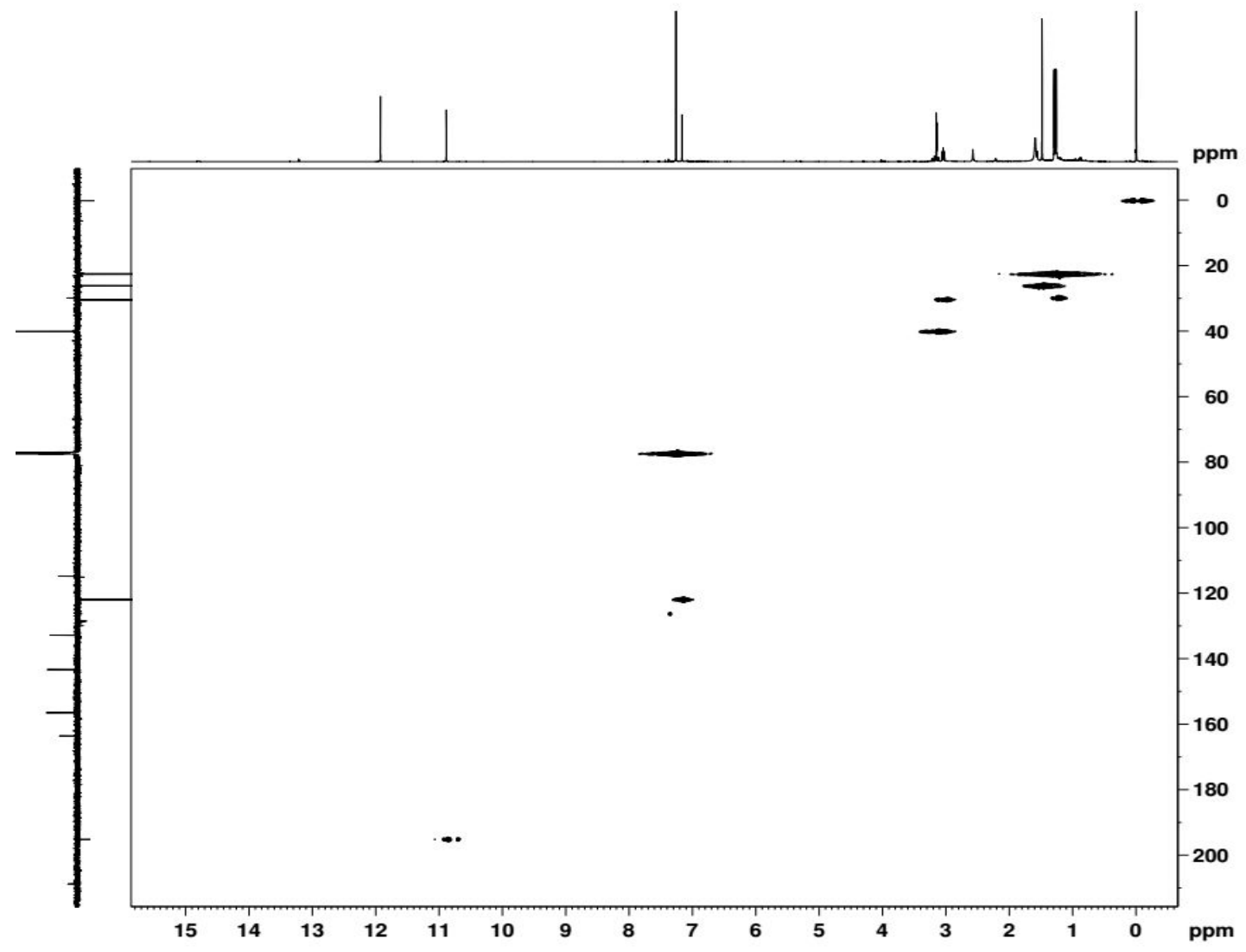

Figure S12. HSQC spectrum of the new compound 2

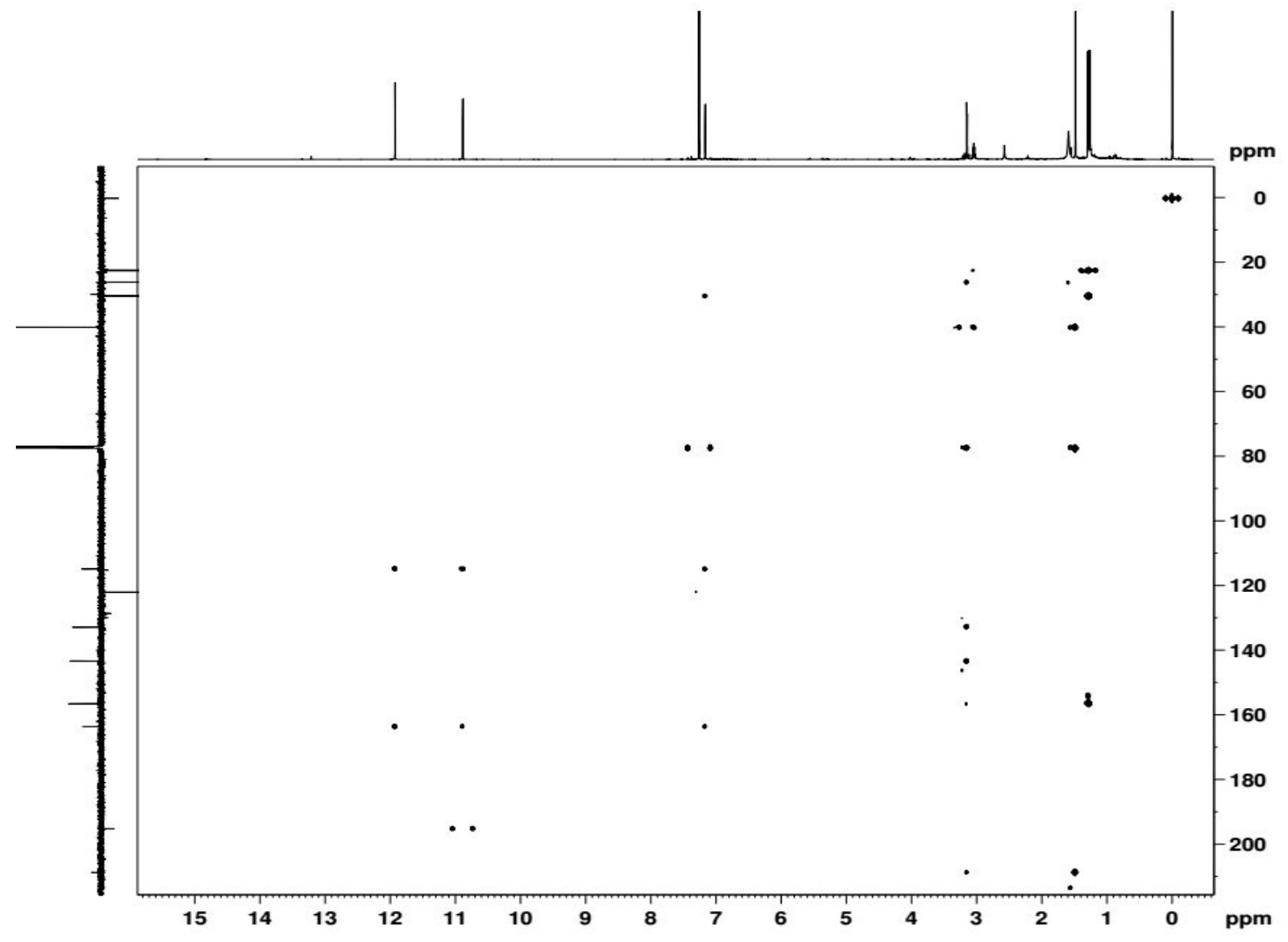

Figure S13. HMBC spectrum of the new compound 2 


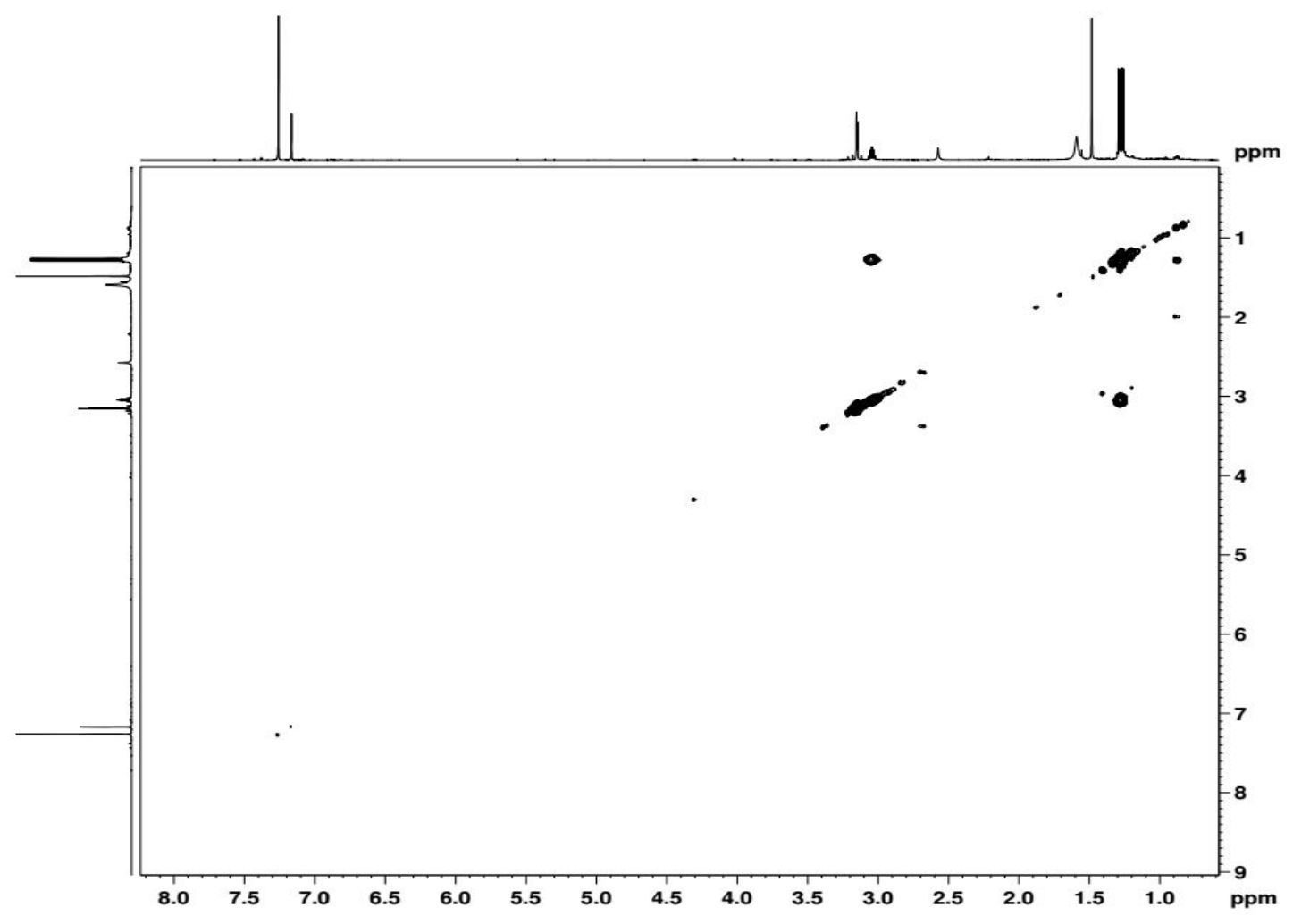

Figure S14. ${ }^{1} \mathrm{H}-{ }^{1} \mathrm{H}$ COSY spectrum of the new compound 2

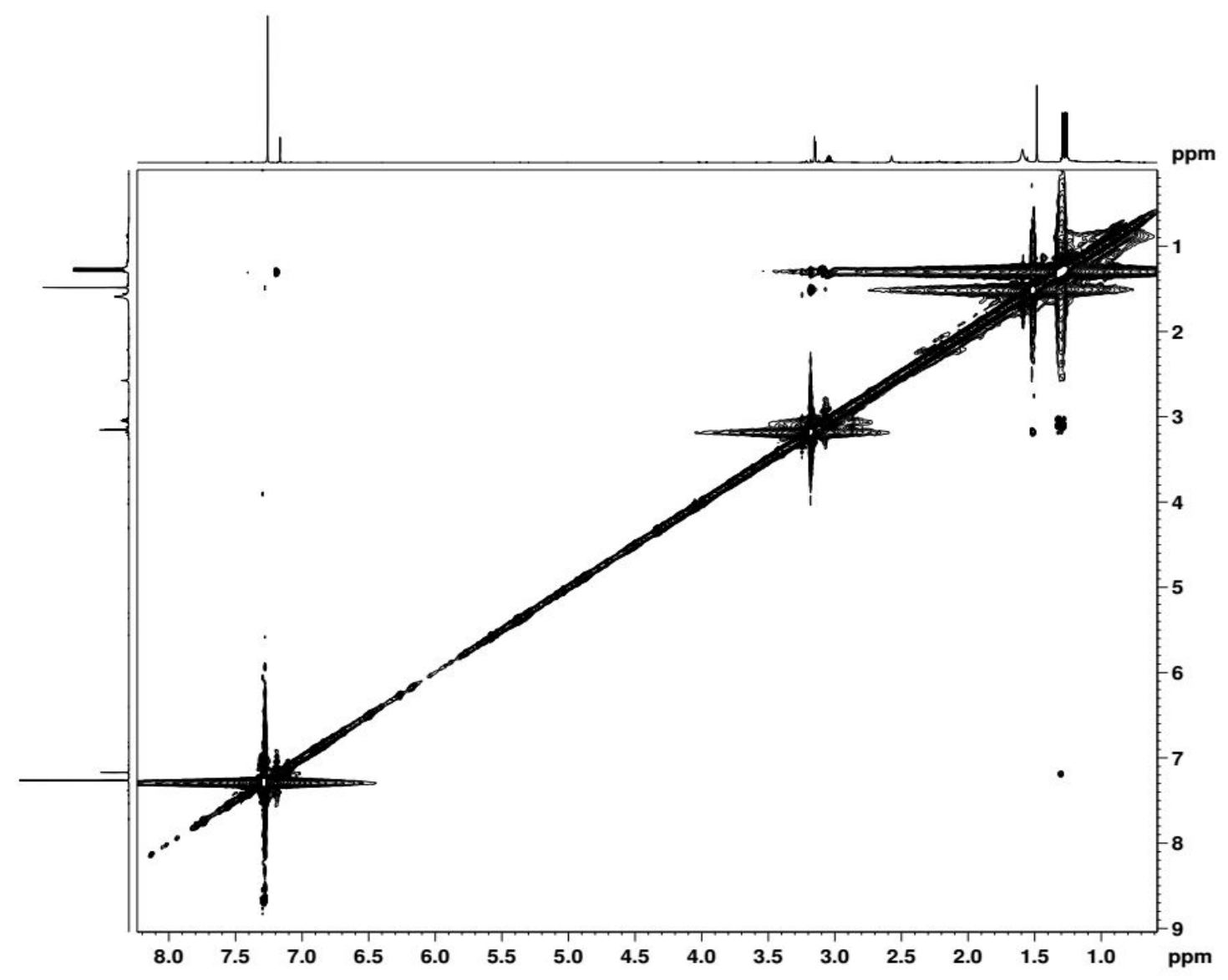

Figure S15. ROESY spectrum of the new compound 2 


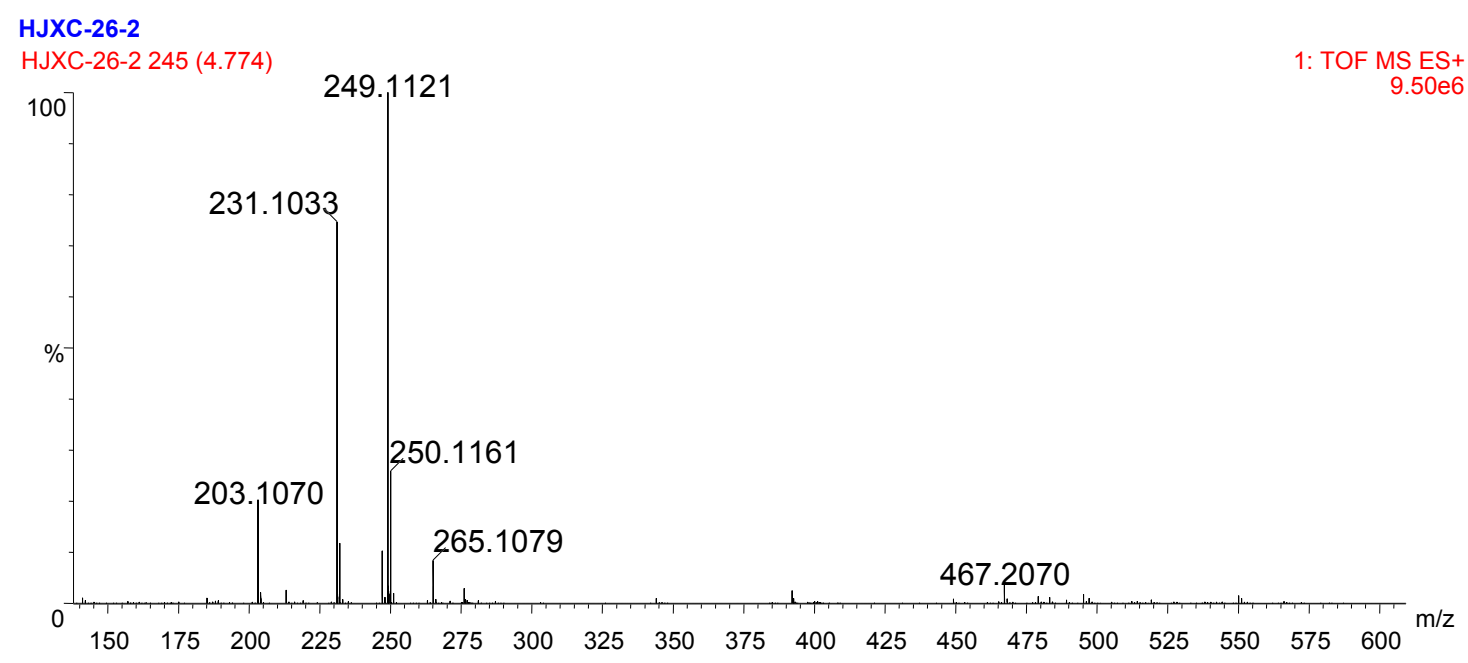

Figure S16. Positive ion HRESIMS of 2

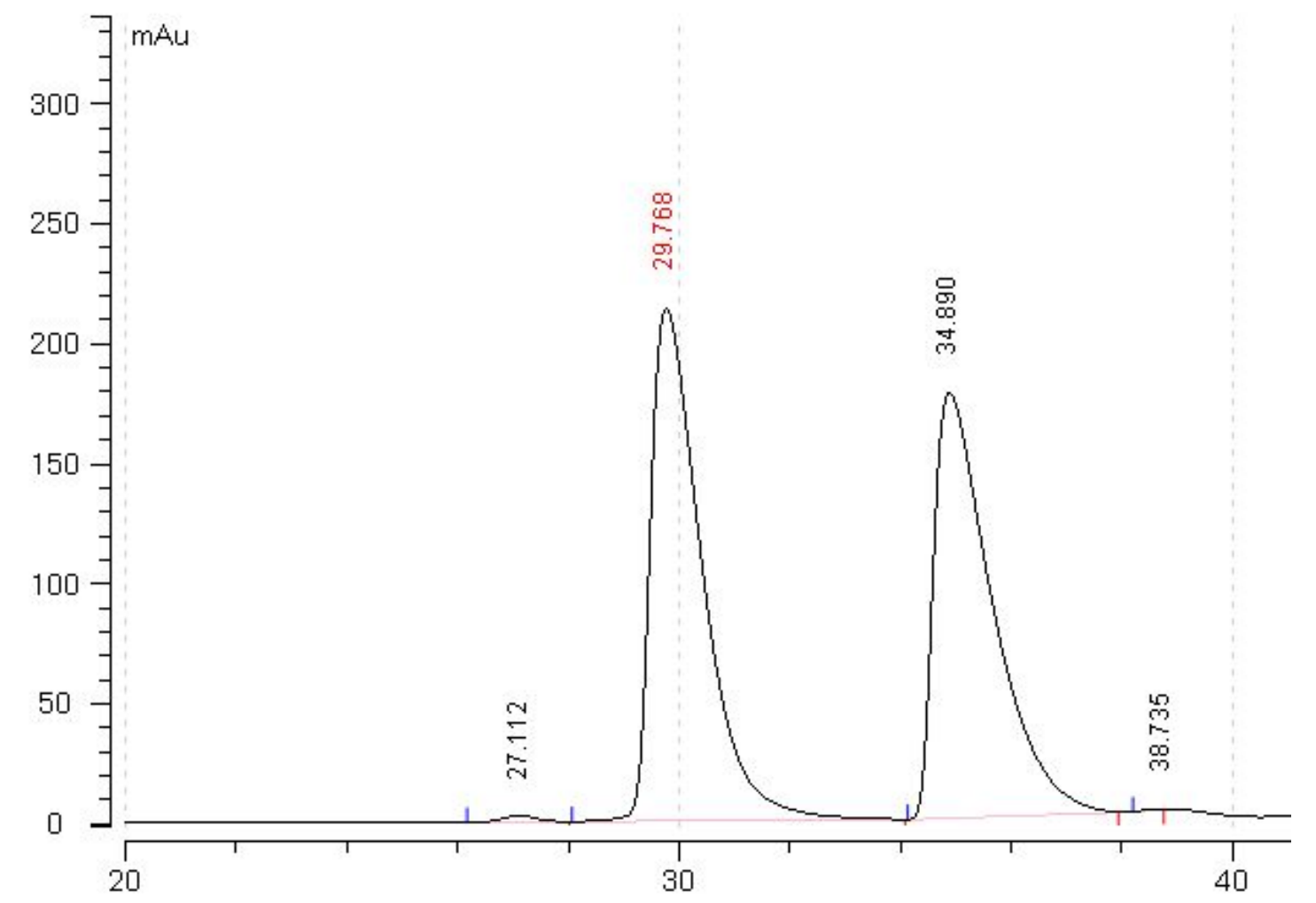

Figure S17. Chiral HPLC analysis of compound 2

(Daicel CHIRALPAK AB-N-5 column, n-Hexane/IPA=95/5, 1.0mL/min) 


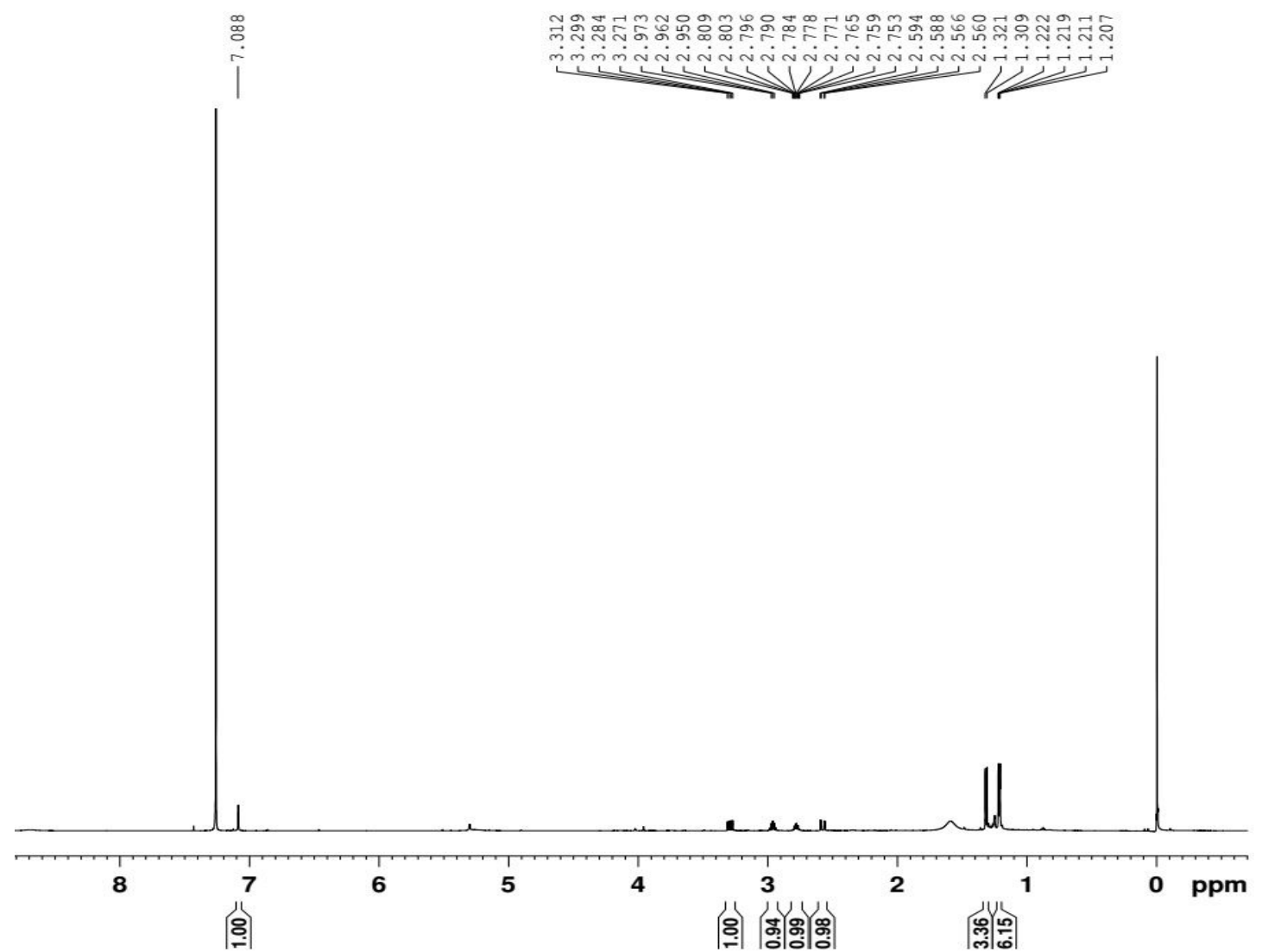

Figure S18. ${ }^{1} \mathrm{H}$ NMR $\left(600 \mathrm{MHz}, \mathrm{CDCl}_{3}\right)$ spectrum of the new compound 3

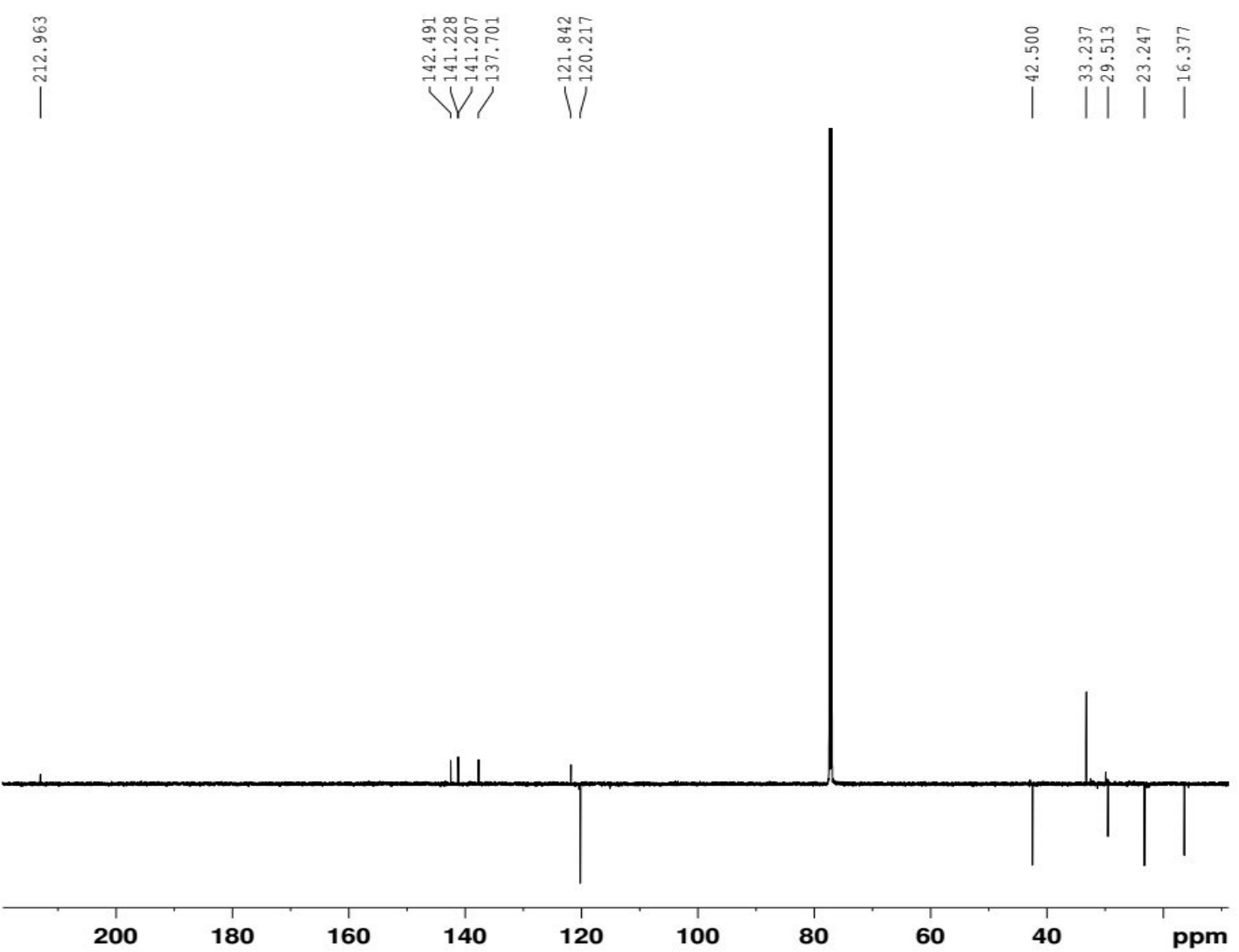

Figure $\mathrm{S} 19 .{ }^{13} \mathrm{C}$ APT $\left(150 \mathrm{MHz}, \mathrm{CDCl}_{3}\right)$ spectrum of the new compound 3 


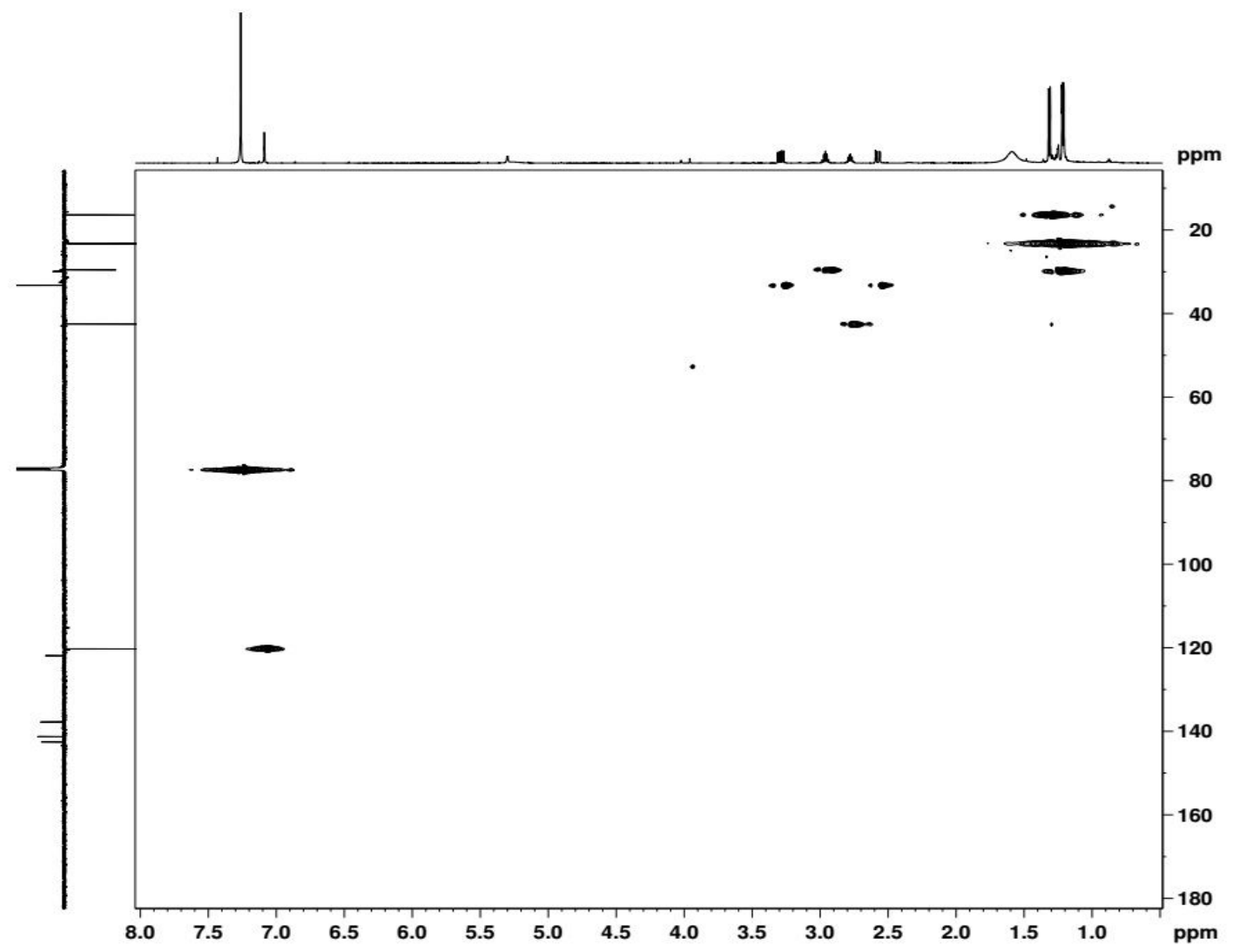

Figure S20. HSQC spectrum of the new compound $\mathbf{3}$

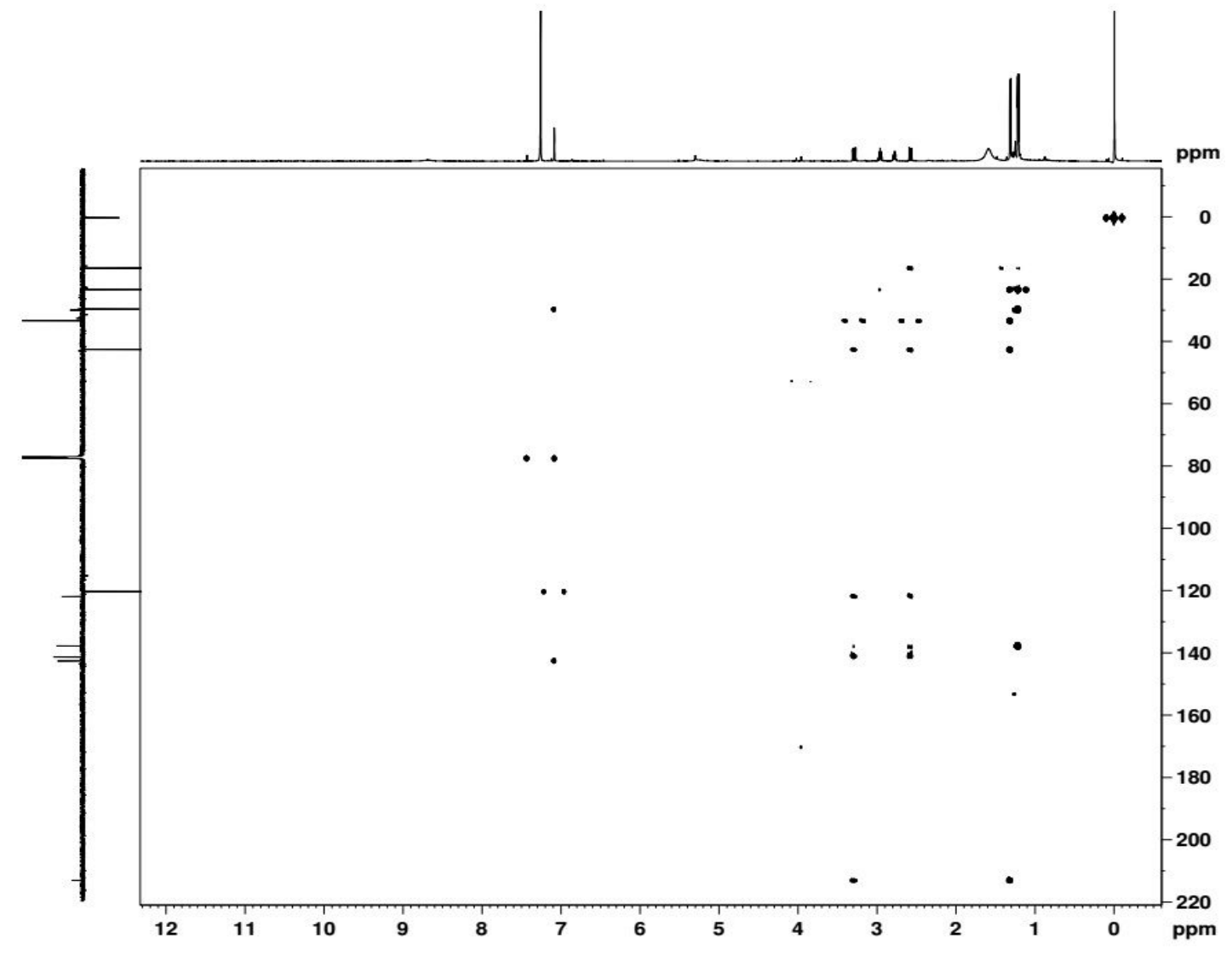

Figure S21. HMBC spectrum of the new compound 3 


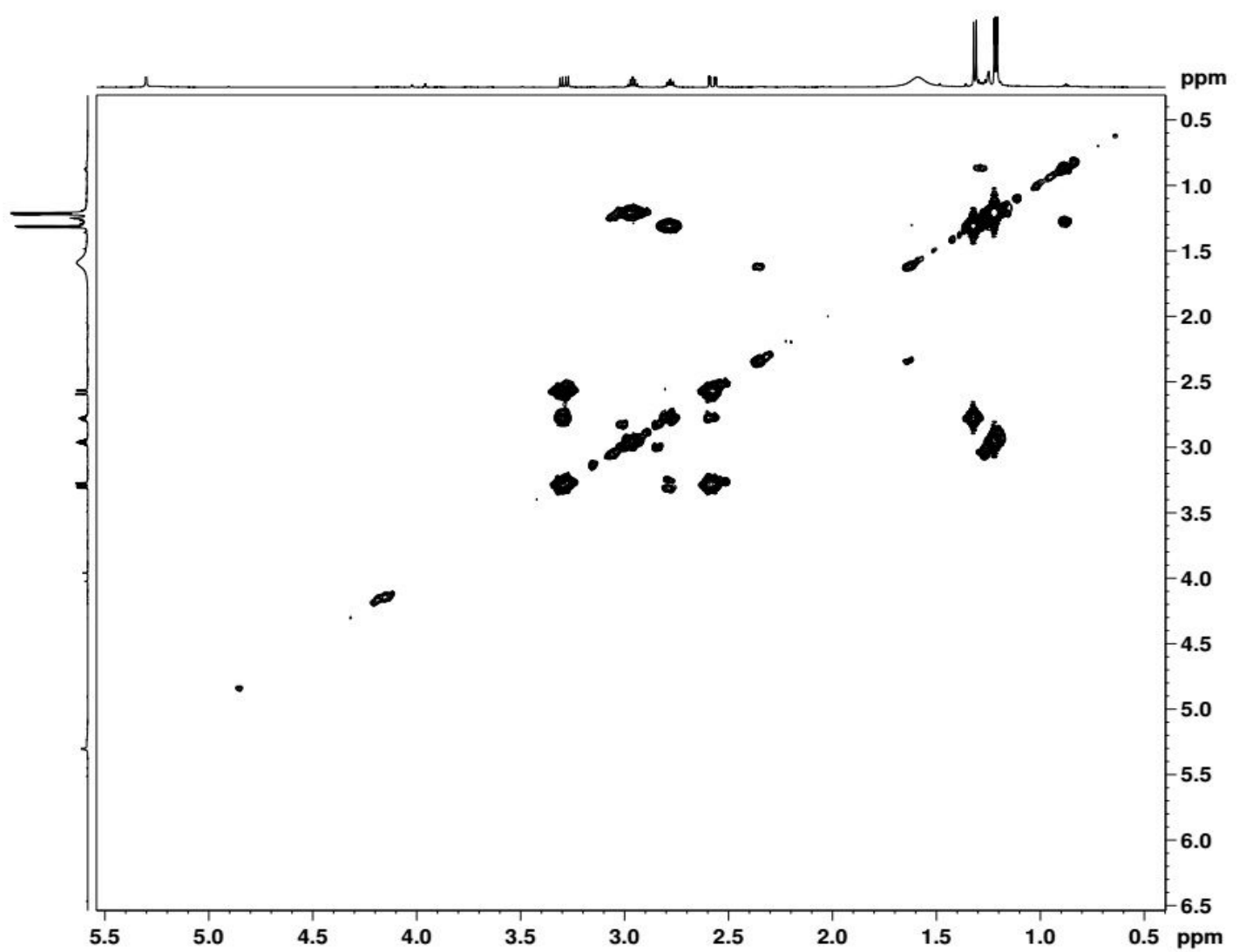

Figure S22. ${ }^{1} \mathrm{H}-{ }^{1} \mathrm{H}$ COSY spectrum of the new compound $\mathbf{3}$

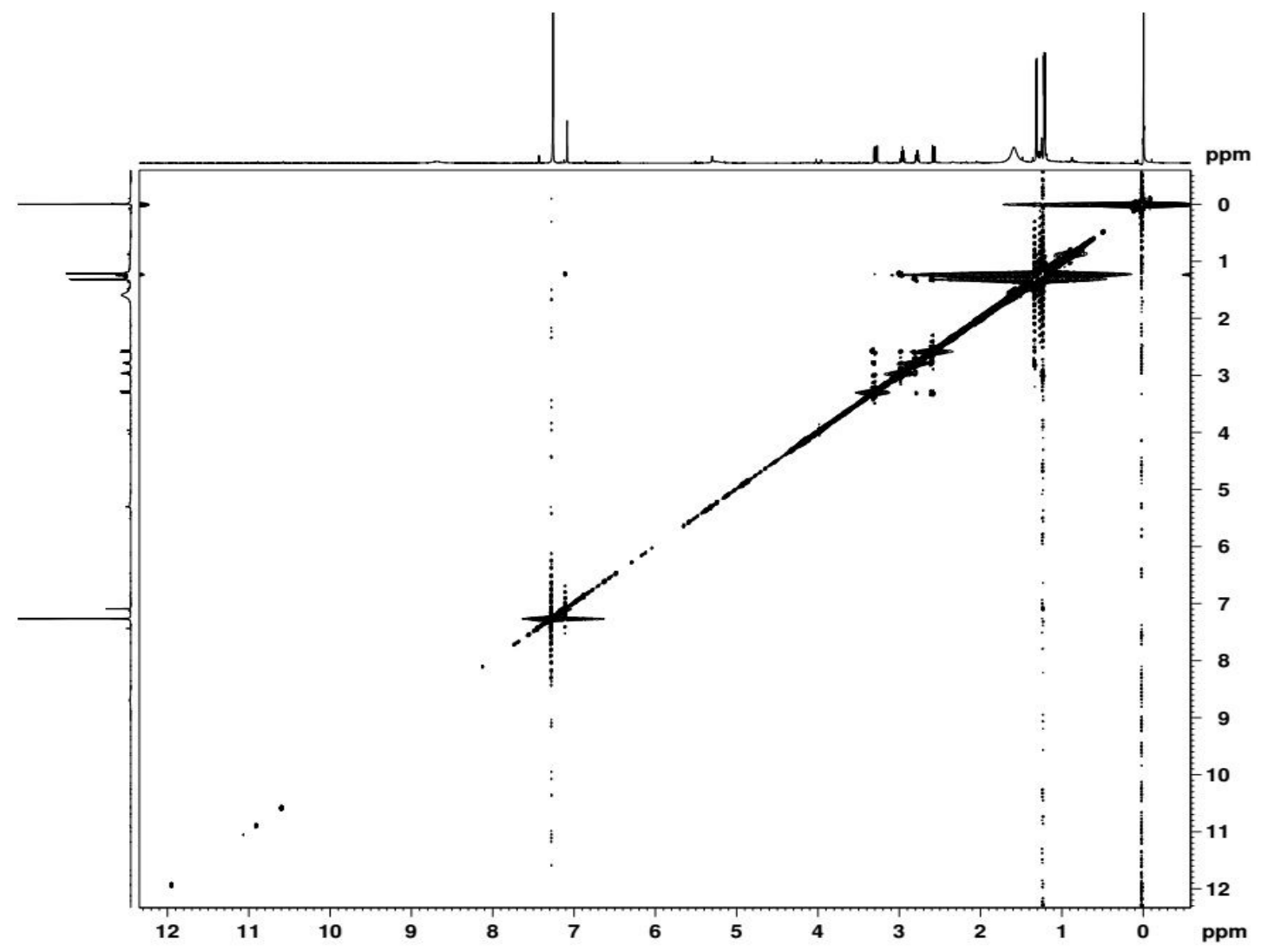

Figure S23. ROESY spectrum of the new compound $\mathbf{3}$ 


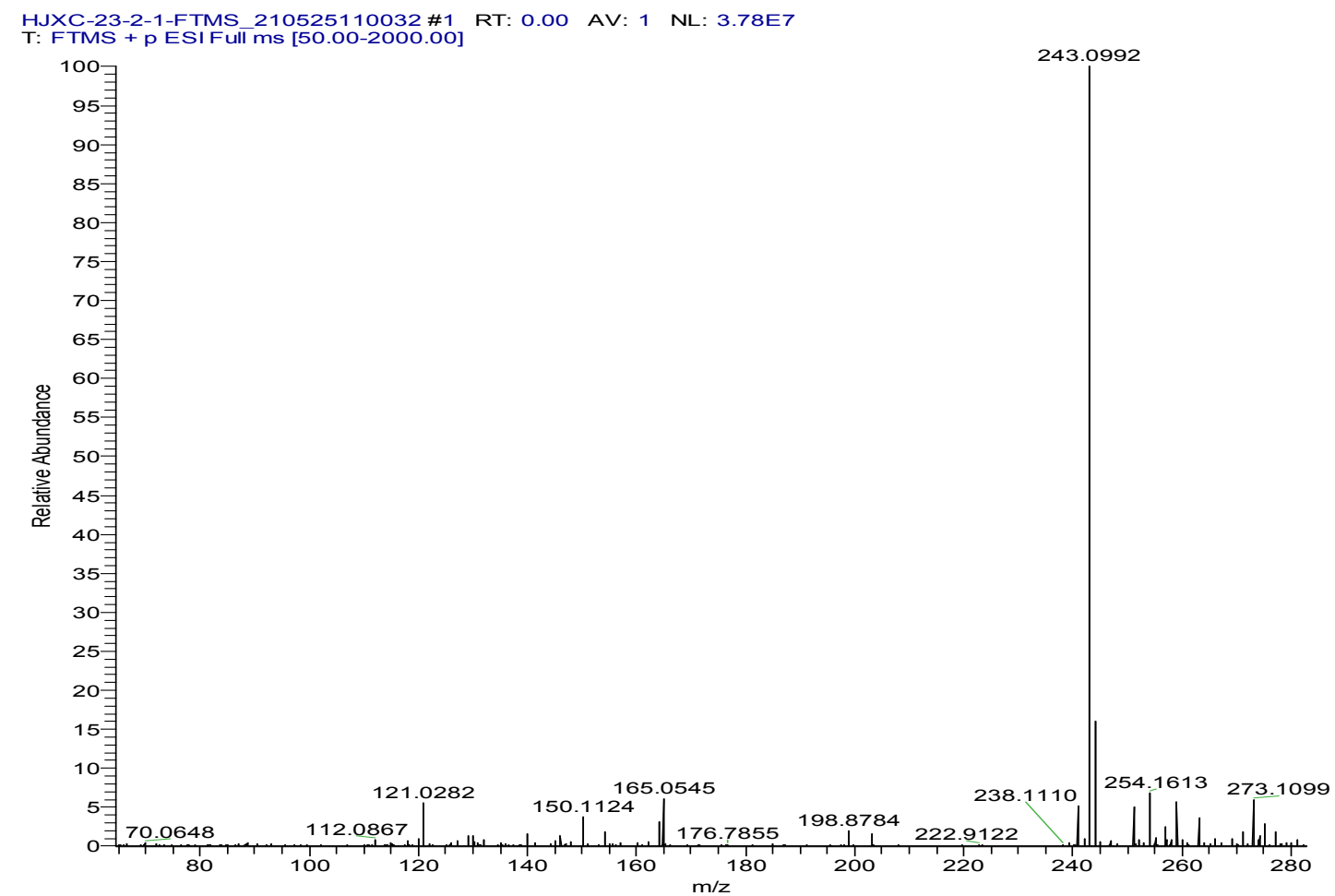

Figure S24. Positive ion HRESIMS of 3

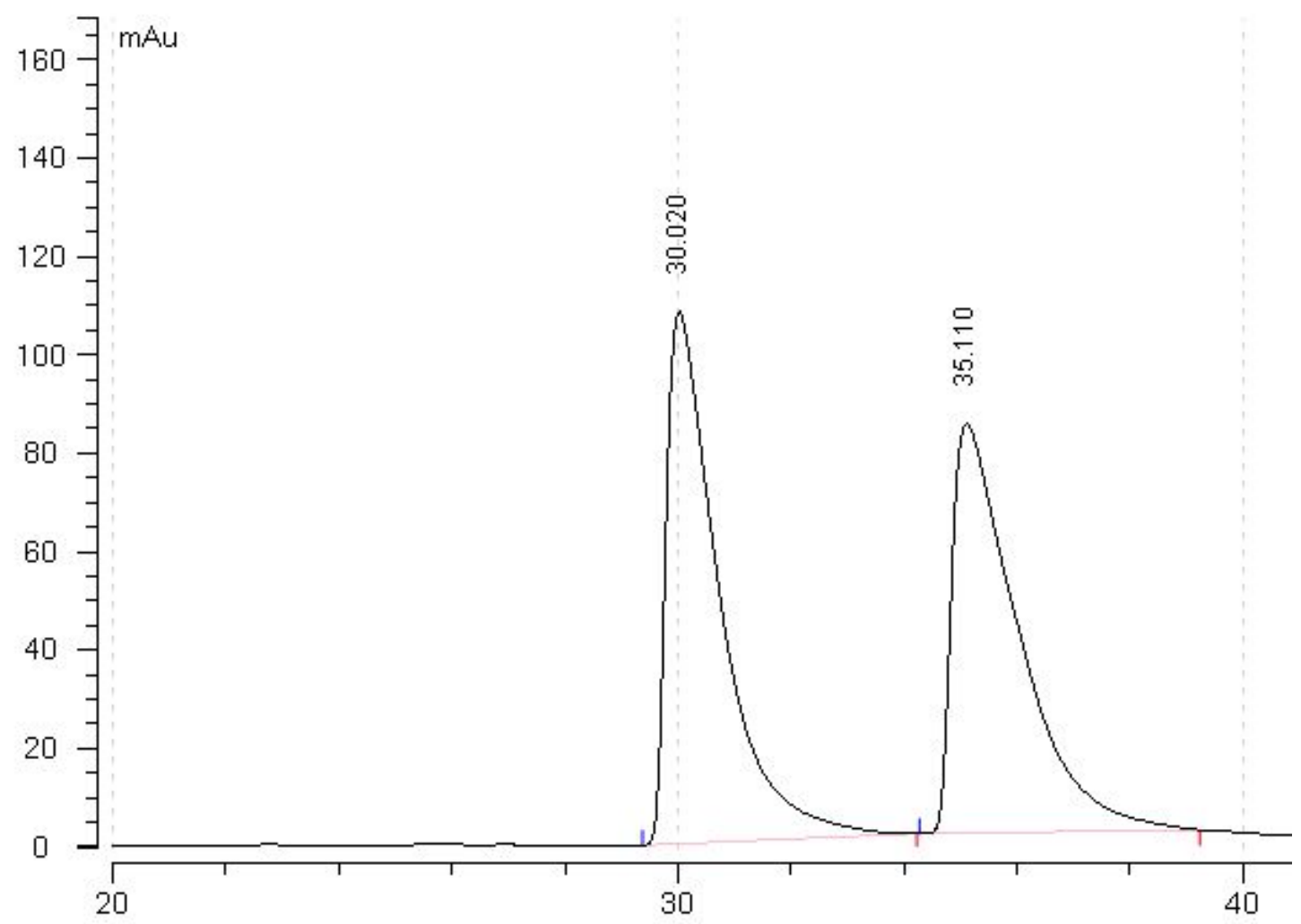

Figure S25. Chiral HPLC analysis of compound 3

(Daicel CHIRALPAK AB-N-5 column, n-Hexane/IPA=98/2, 1.0mL/min) 

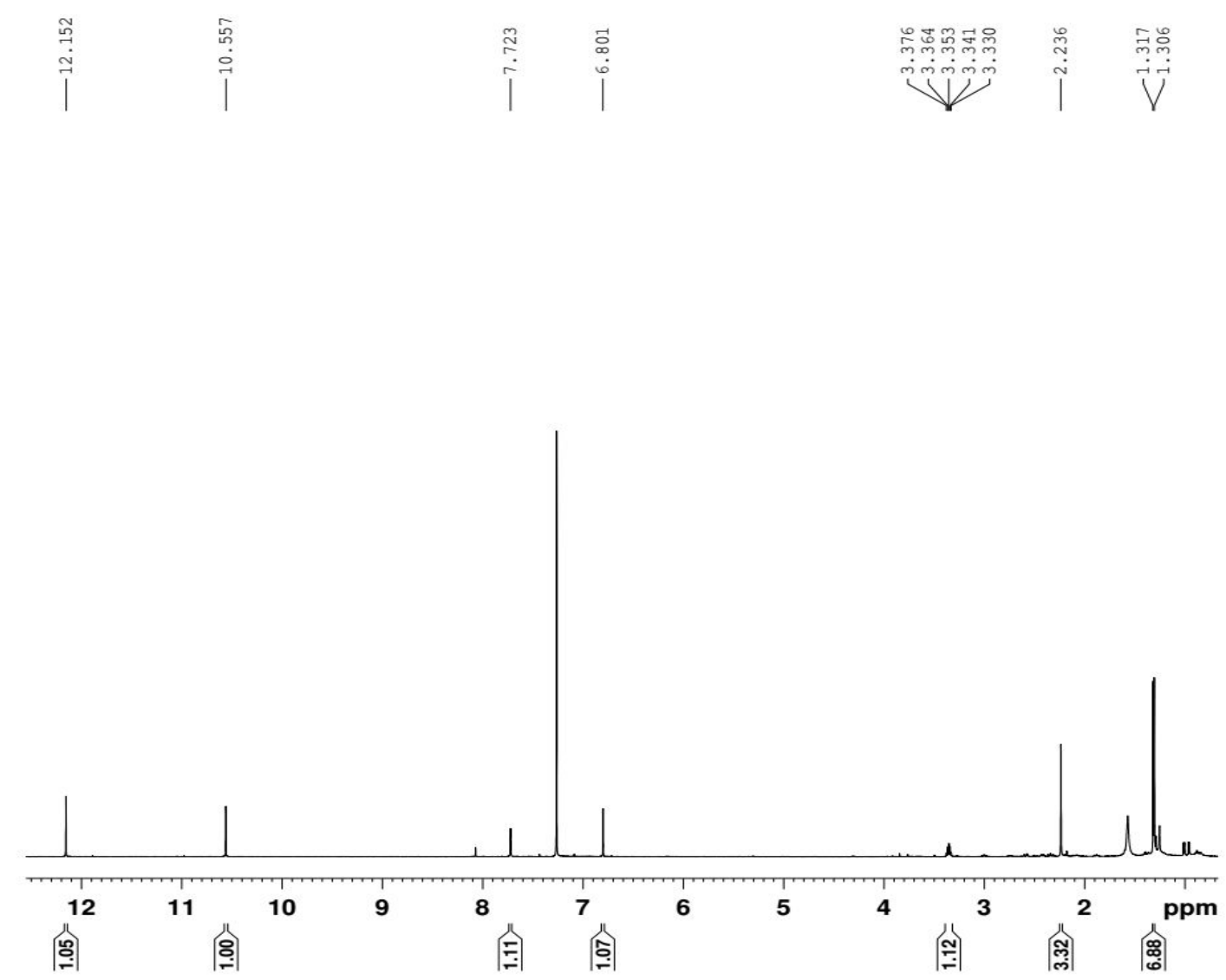

Figure S26. ${ }^{1} \mathrm{H} \mathrm{NMR}\left(600 \mathrm{MHz}, \mathrm{CDCl}_{3}\right)$ spectrum of the new compound 4

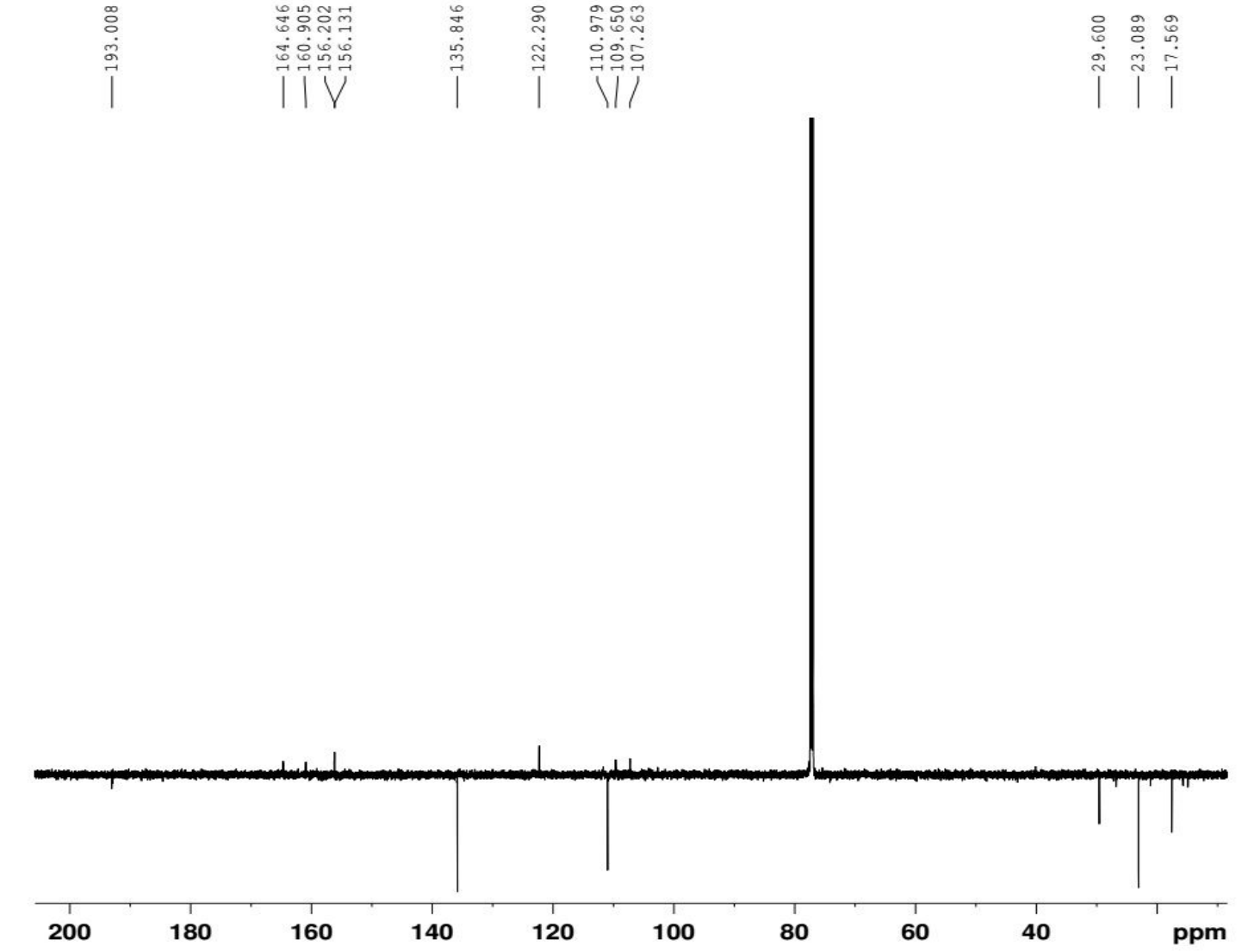

Figure S27. ${ }^{13} \mathrm{C}$ APT $\left(150 \mathrm{MHz}, \mathrm{CDCl}_{3}\right)$ spectrum of the new compound 4 


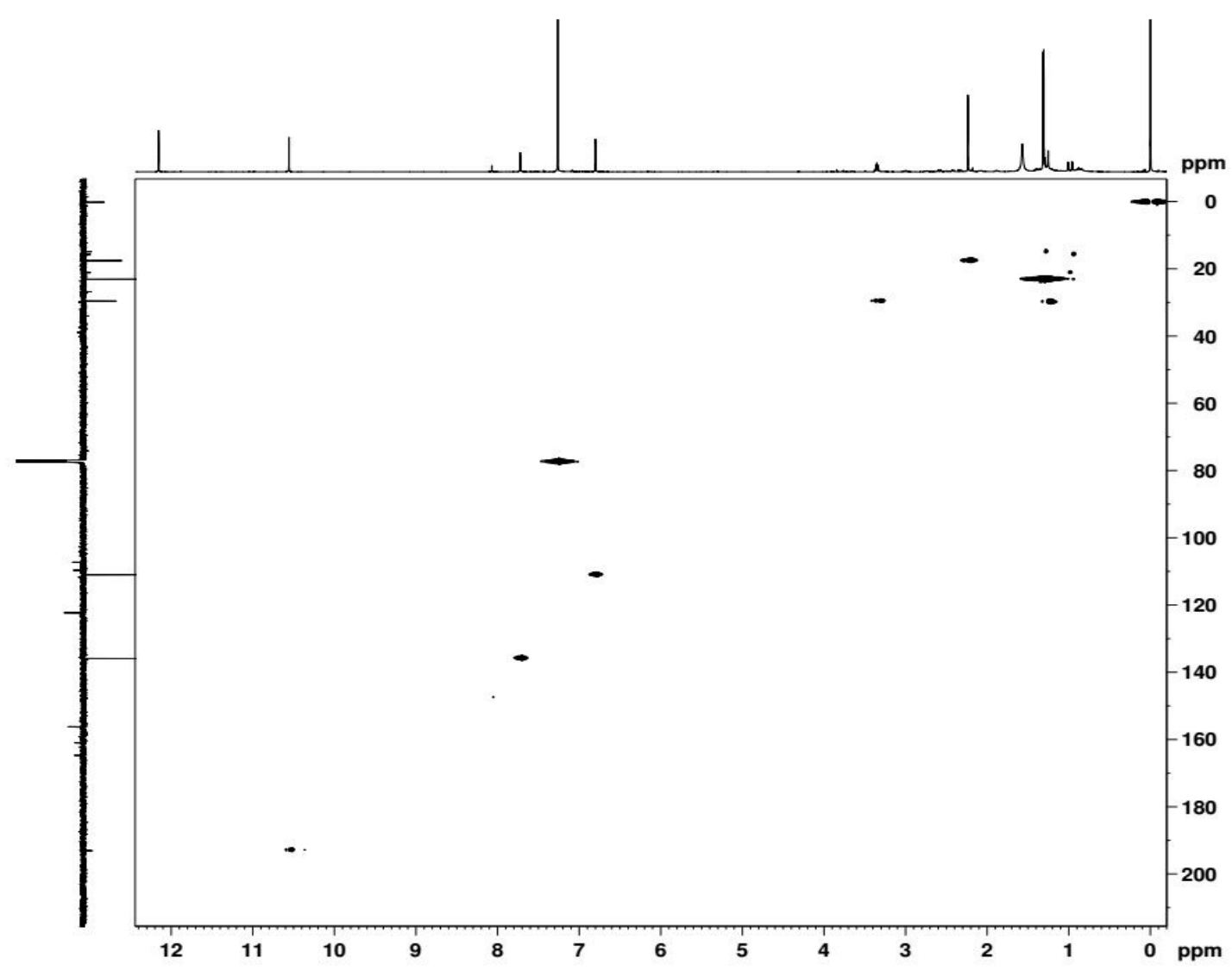

Figure S28. HSQC spectrum of the new compound 4

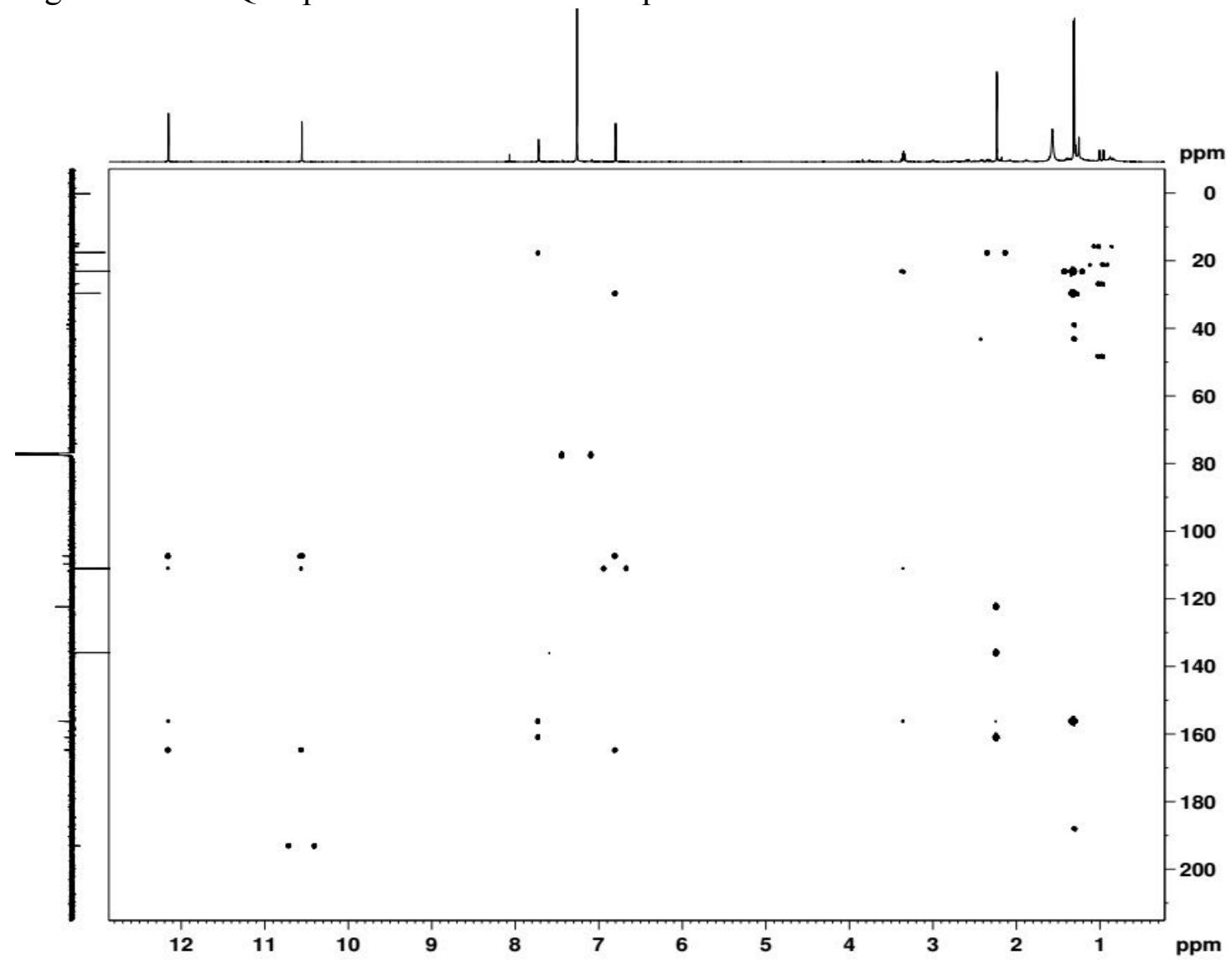

Figure S29. HMBC spectrum of the new compound 4 


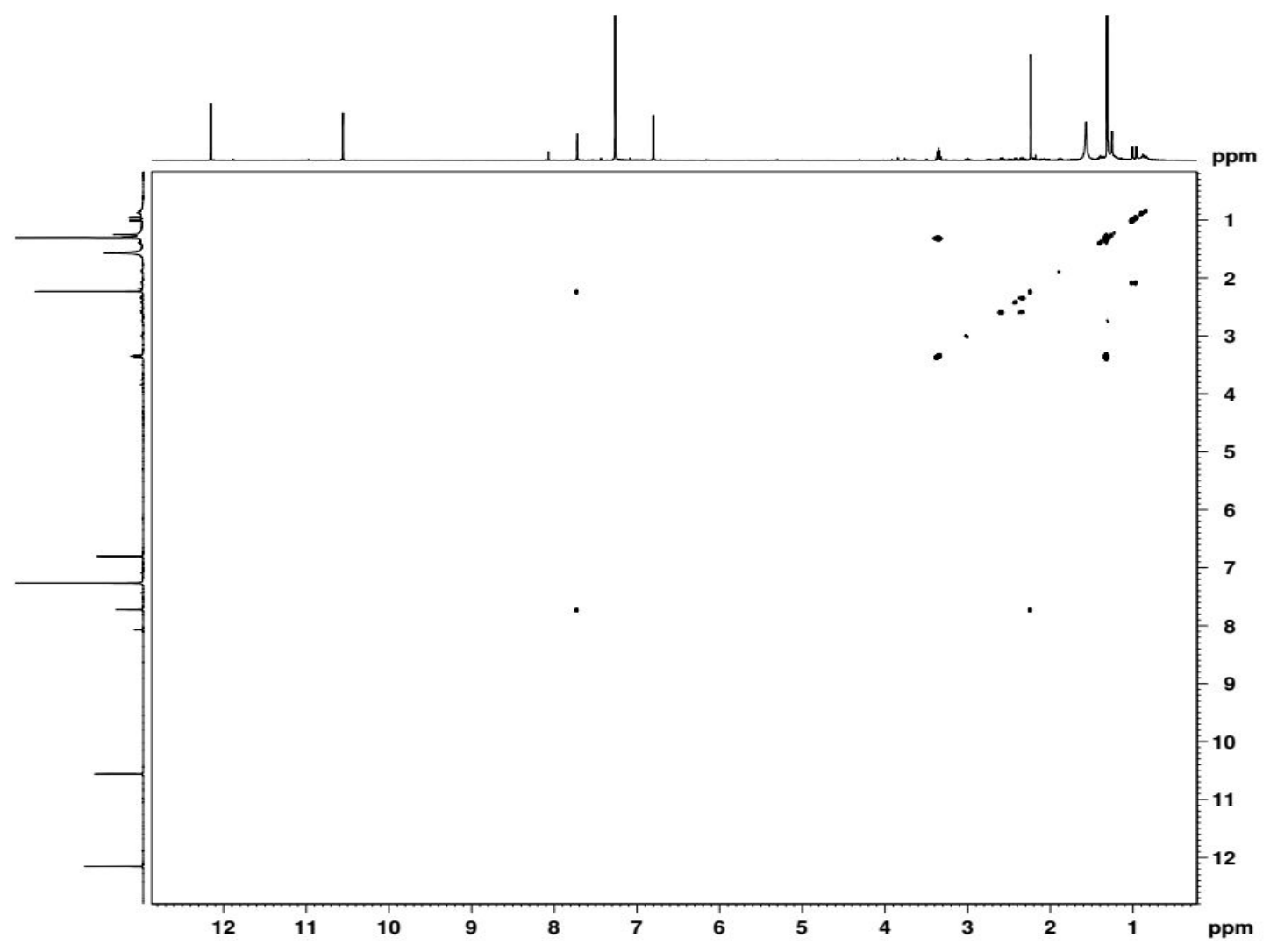

Figure S30. ${ }^{1} \mathrm{H}-{ }^{1} \mathrm{H}$ COSY spectrum of the new compound 4

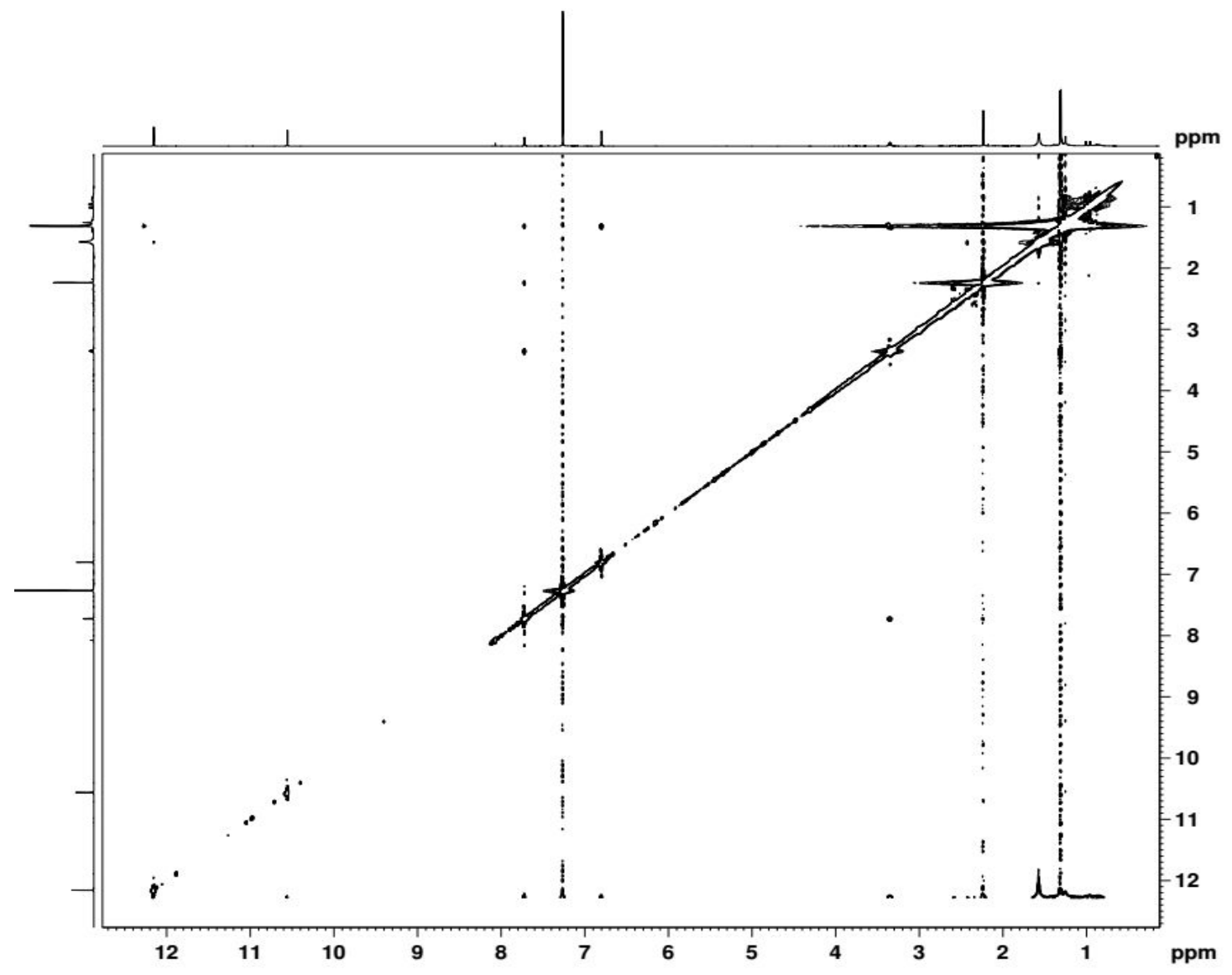

Figure S31. ROESY spectrum of the new compound 4 


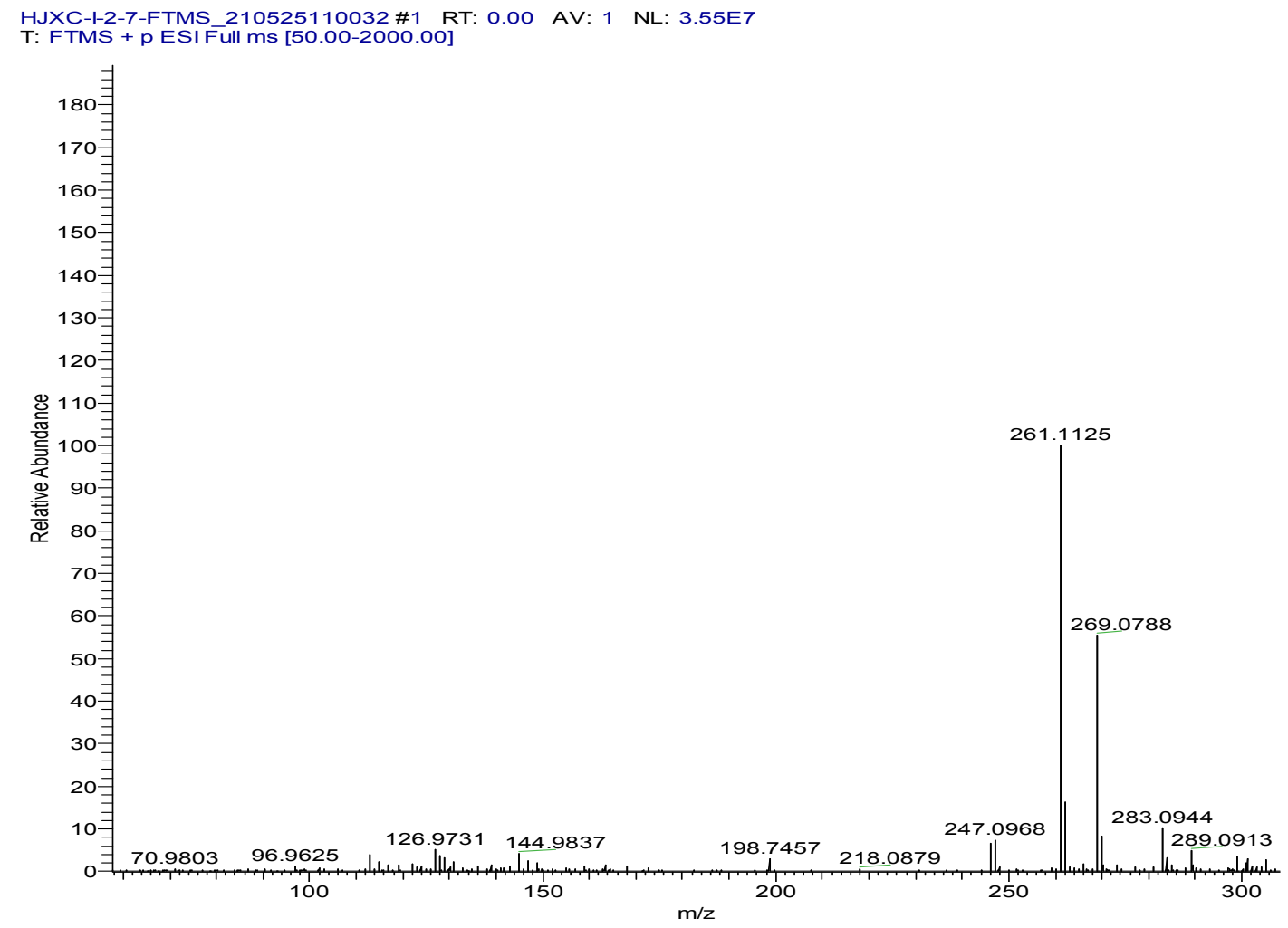

Figure S32. Positive ion HRESIMS of 4

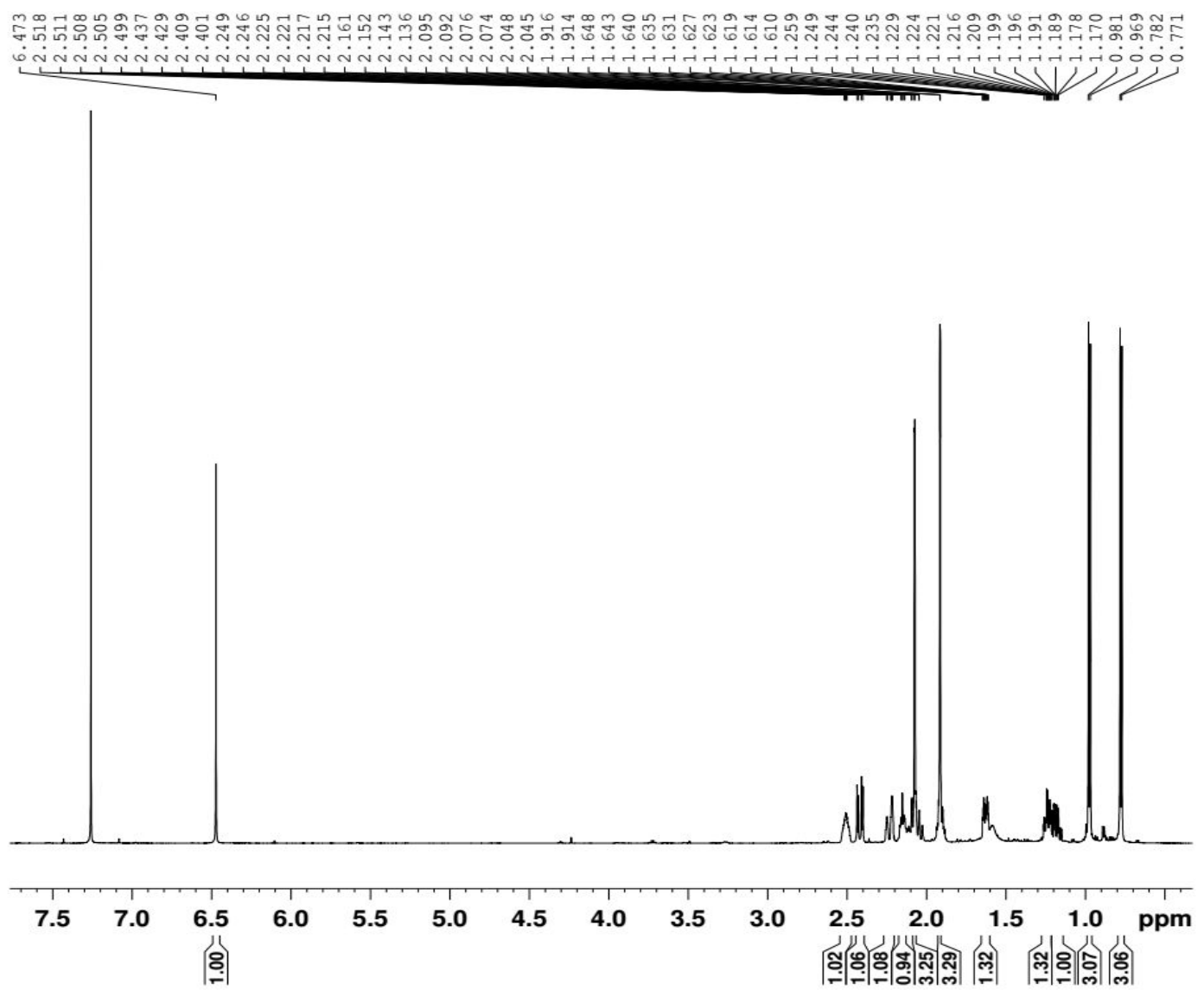

Figure $\mathrm{S} 33 .{ }^{1} \mathrm{H} \mathrm{NMR}\left(600 \mathrm{MHz}, \mathrm{CDCl}_{3}\right)$ spectrum of the new compound 5 


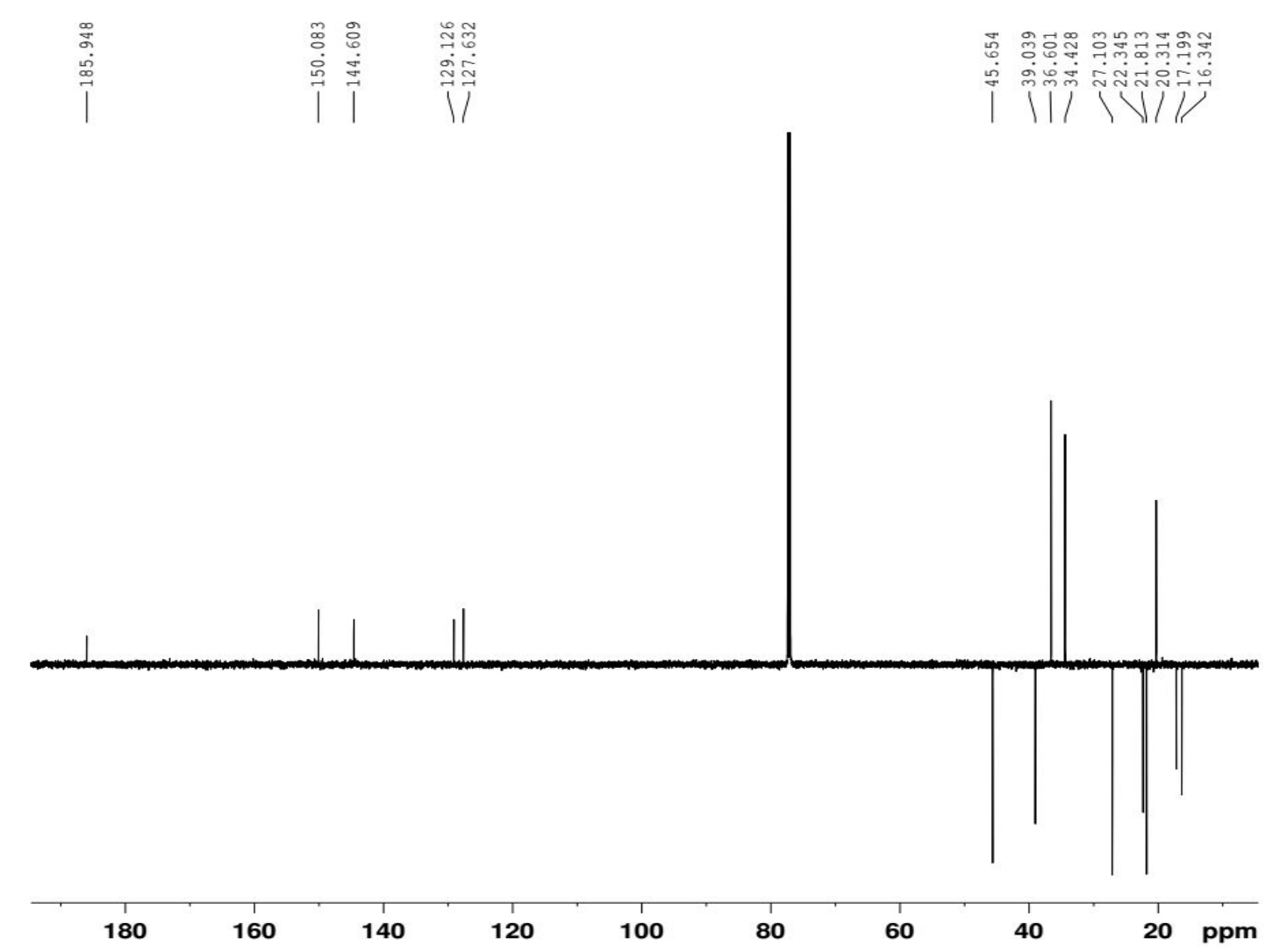

Figure $\mathrm{S} 34 .{ }^{13} \mathrm{C}$ APT $\left(150 \mathrm{MHz}, \mathrm{CDCl}_{3}\right)$ spectrum of the new compound $\mathbf{5}$

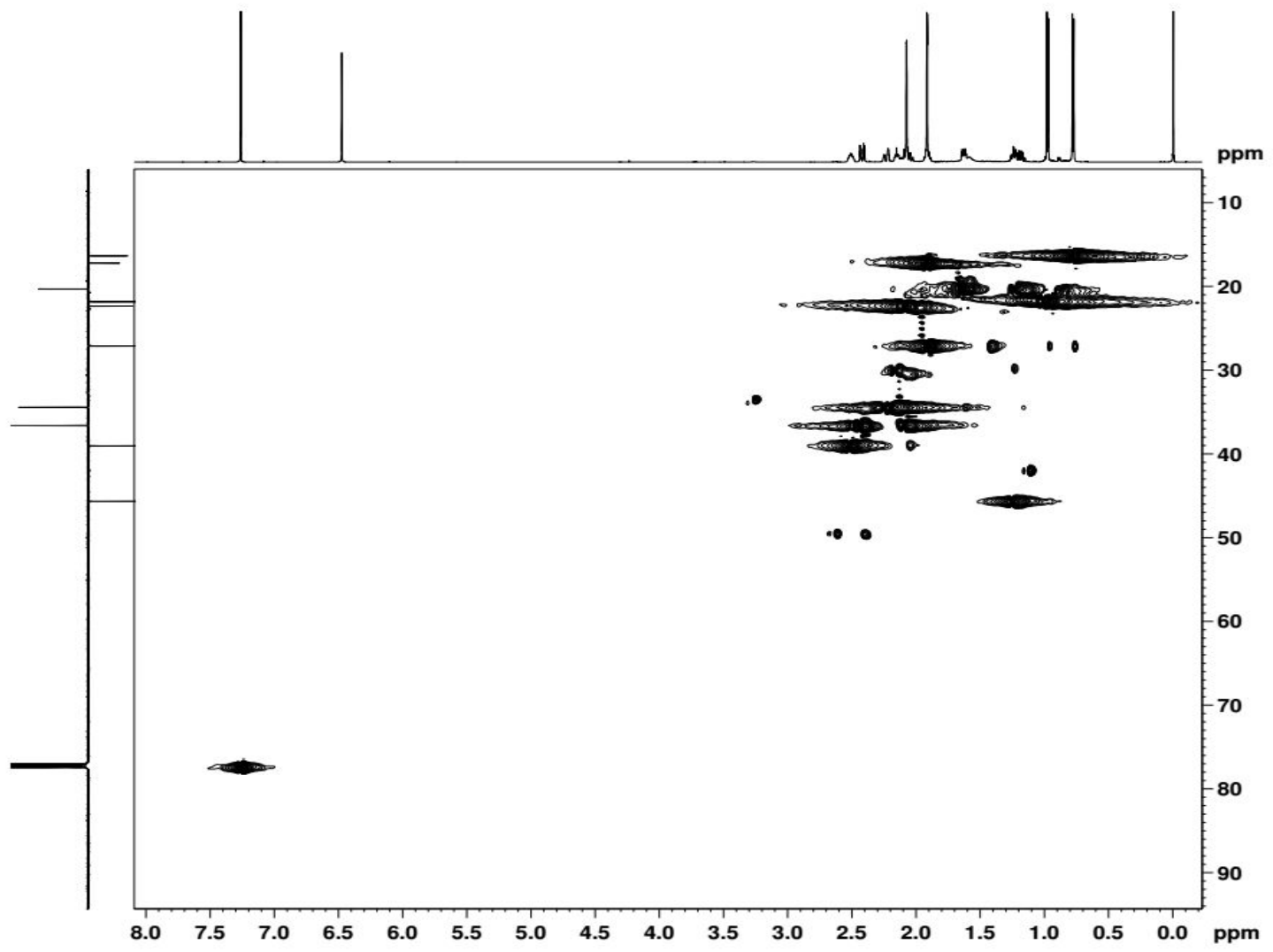

Figure S35. HSQC spectrum of the new compound $\mathbf{5}$ 


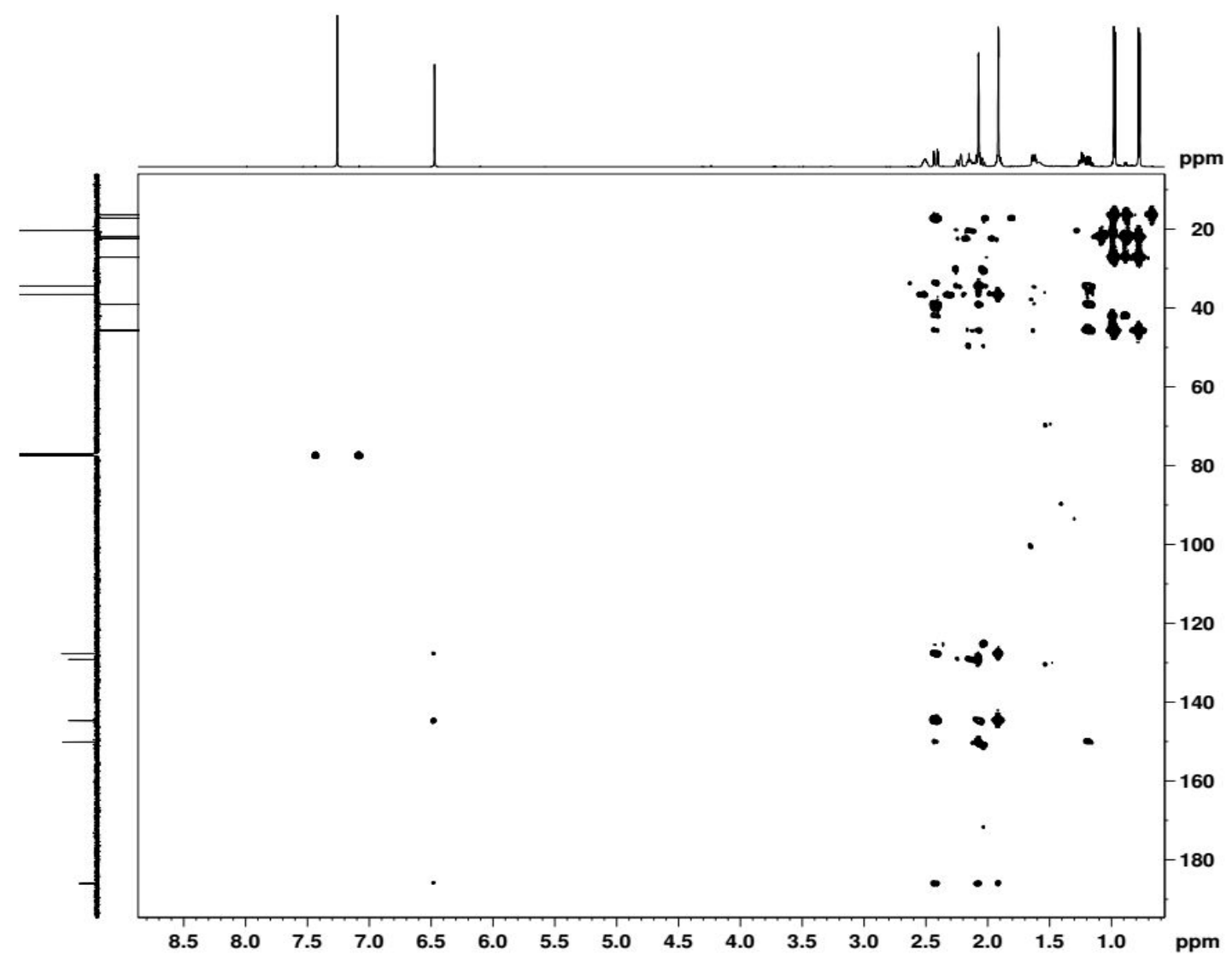

Figure S36. HMBC spectrum of the new compound 5

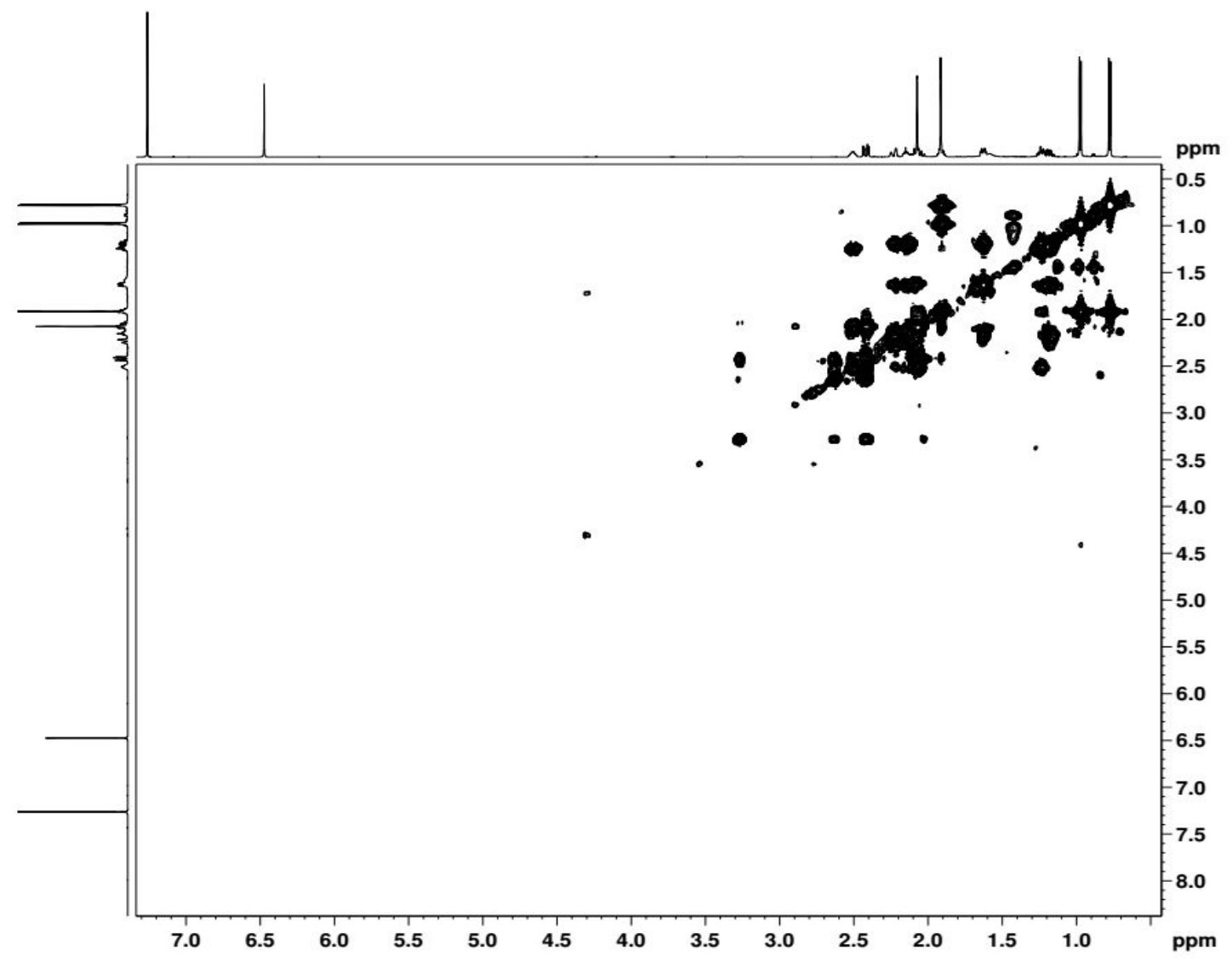

Figure S37. ${ }^{1} \mathrm{H}-{ }^{1} \mathrm{H}$ COSY spectrum of the new compound 5 


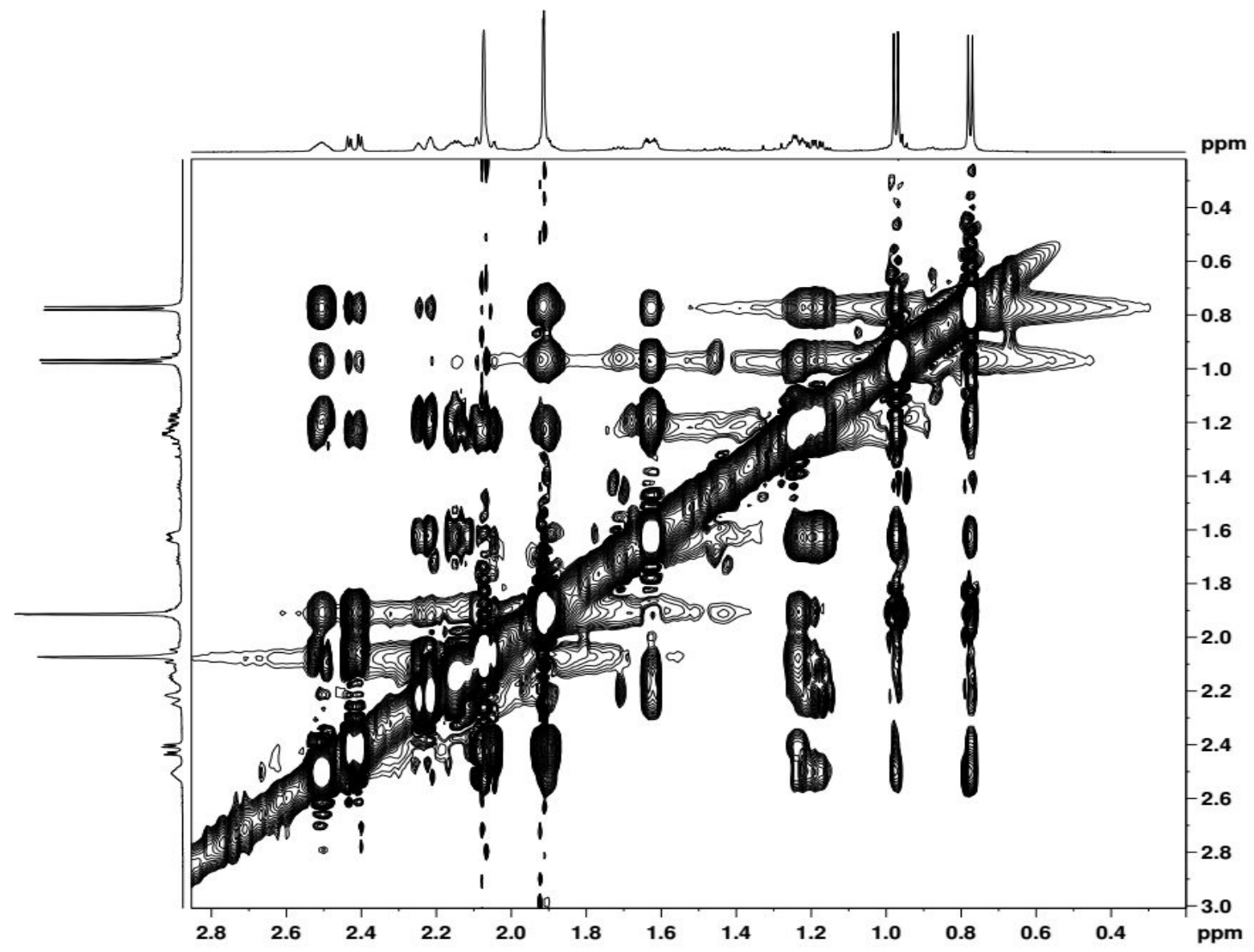

Figure S38. ROESY spectrum of the new compound $\mathbf{5}$

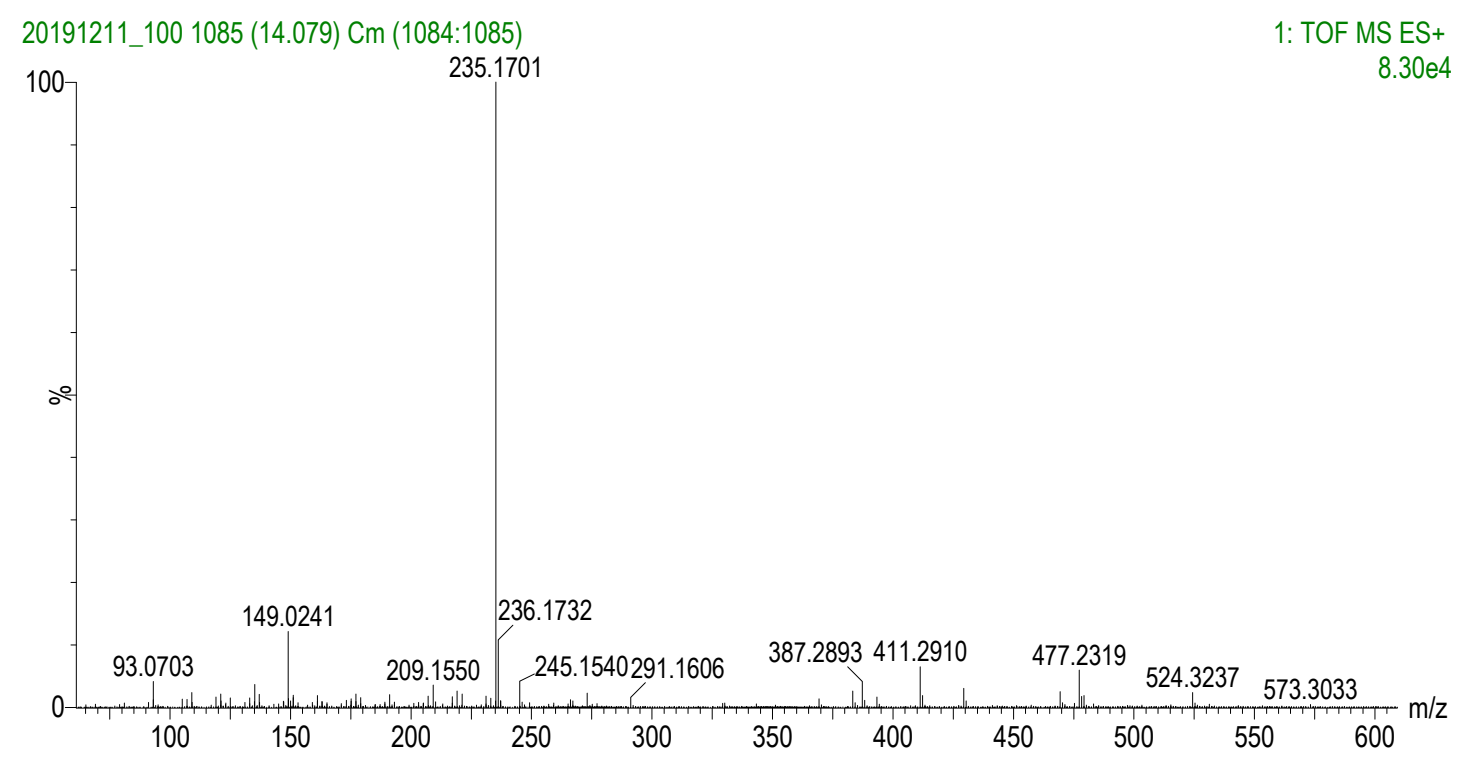

Figure S39. Positive ion HRESIMS of 5 


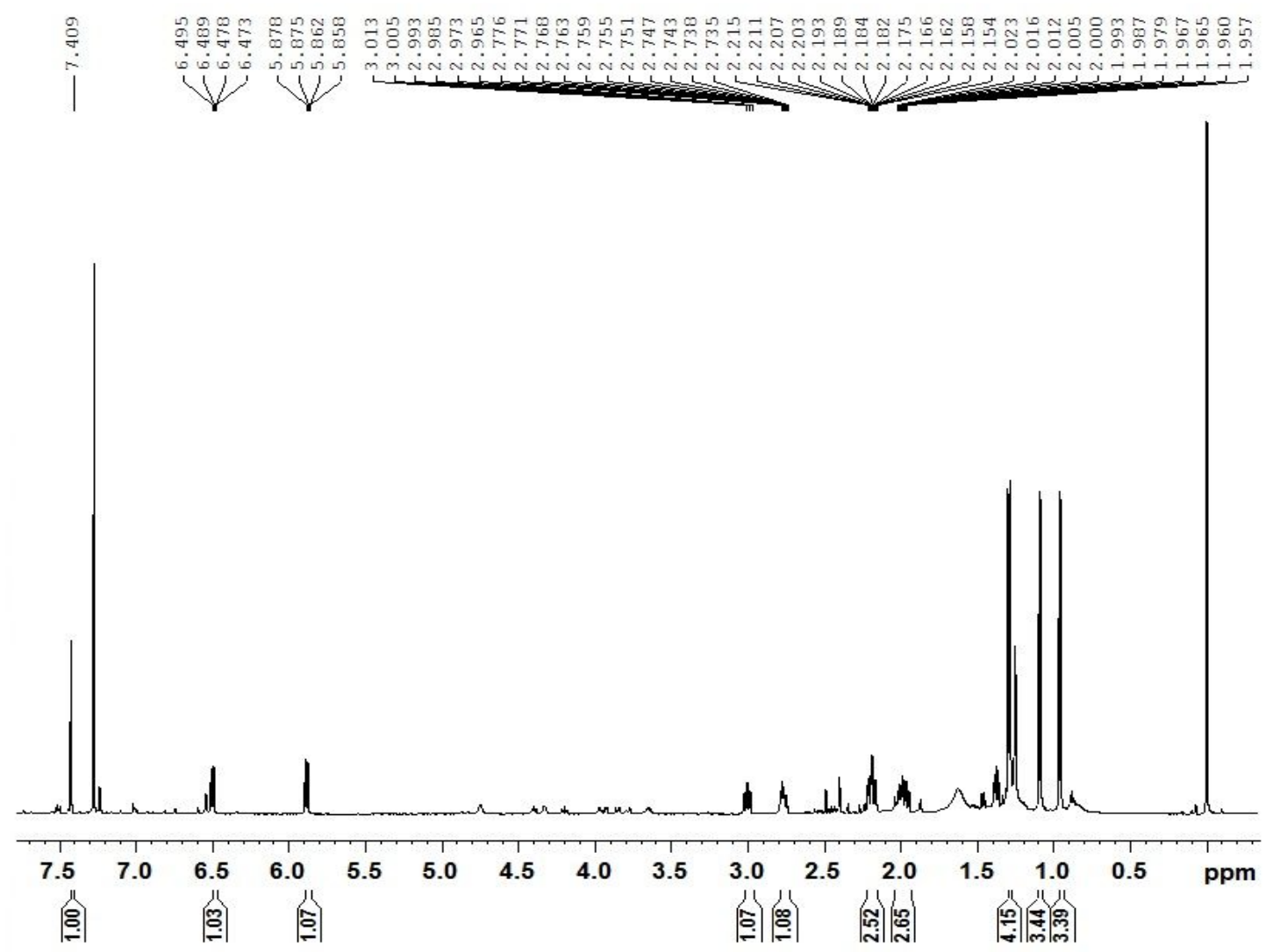

Figure $\mathrm{S} 40 .{ }^{1} \mathrm{H}$ NMR $\left(600 \mathrm{MHz}, \mathrm{CDCl}_{3}\right)$ spectrum of the new compound 6

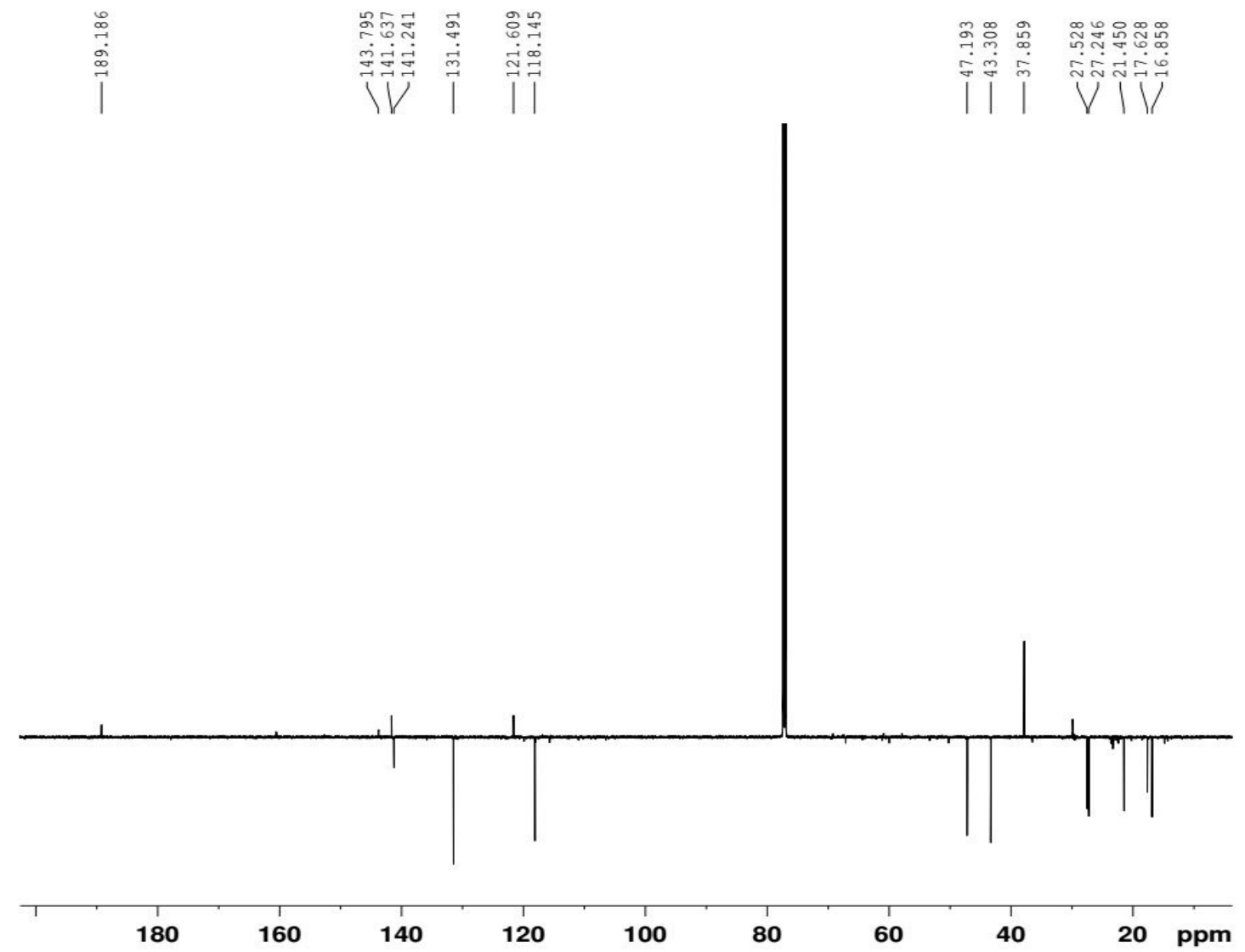

Figure $\mathrm{S} 41 .{ }^{13} \mathrm{C}$ APT $\left(150 \mathrm{MHz}, \mathrm{CDCl}_{3}\right)$ spectrum of the new compound $\mathbf{6}$ 


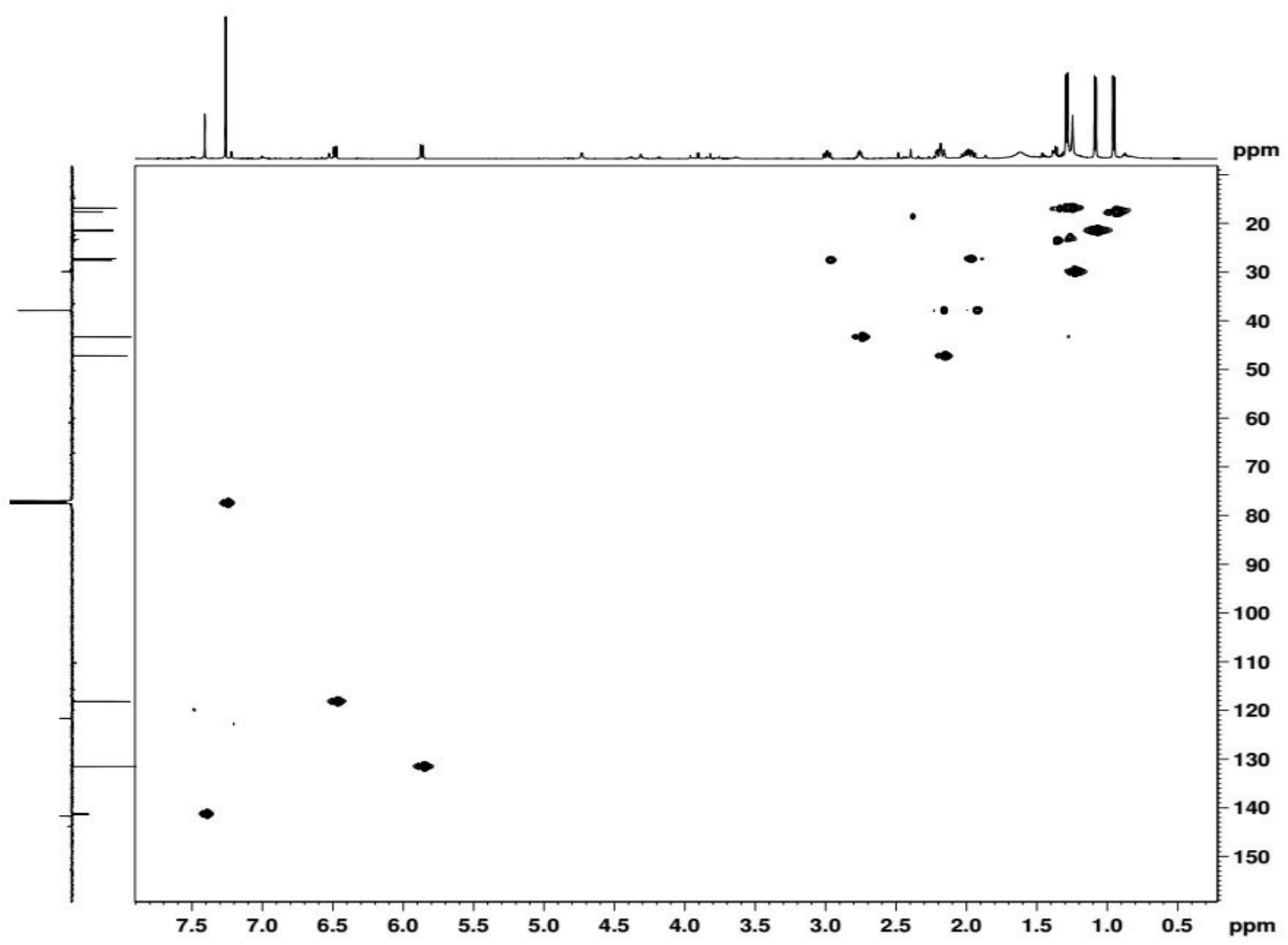

Figure S42. HSQC spectrum of the new compound 6

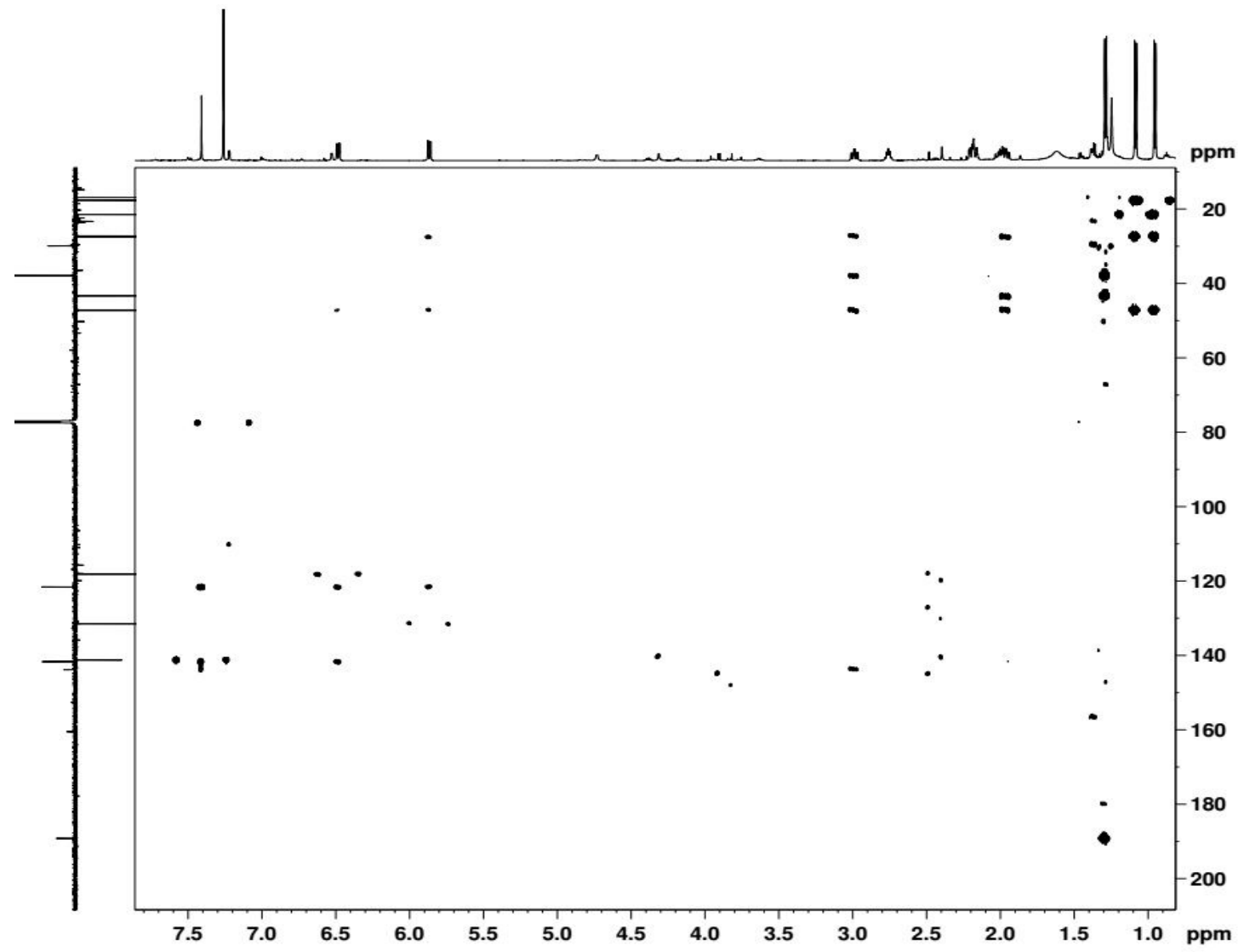

Figure S43. HMBC spectrum of the new compound 6 


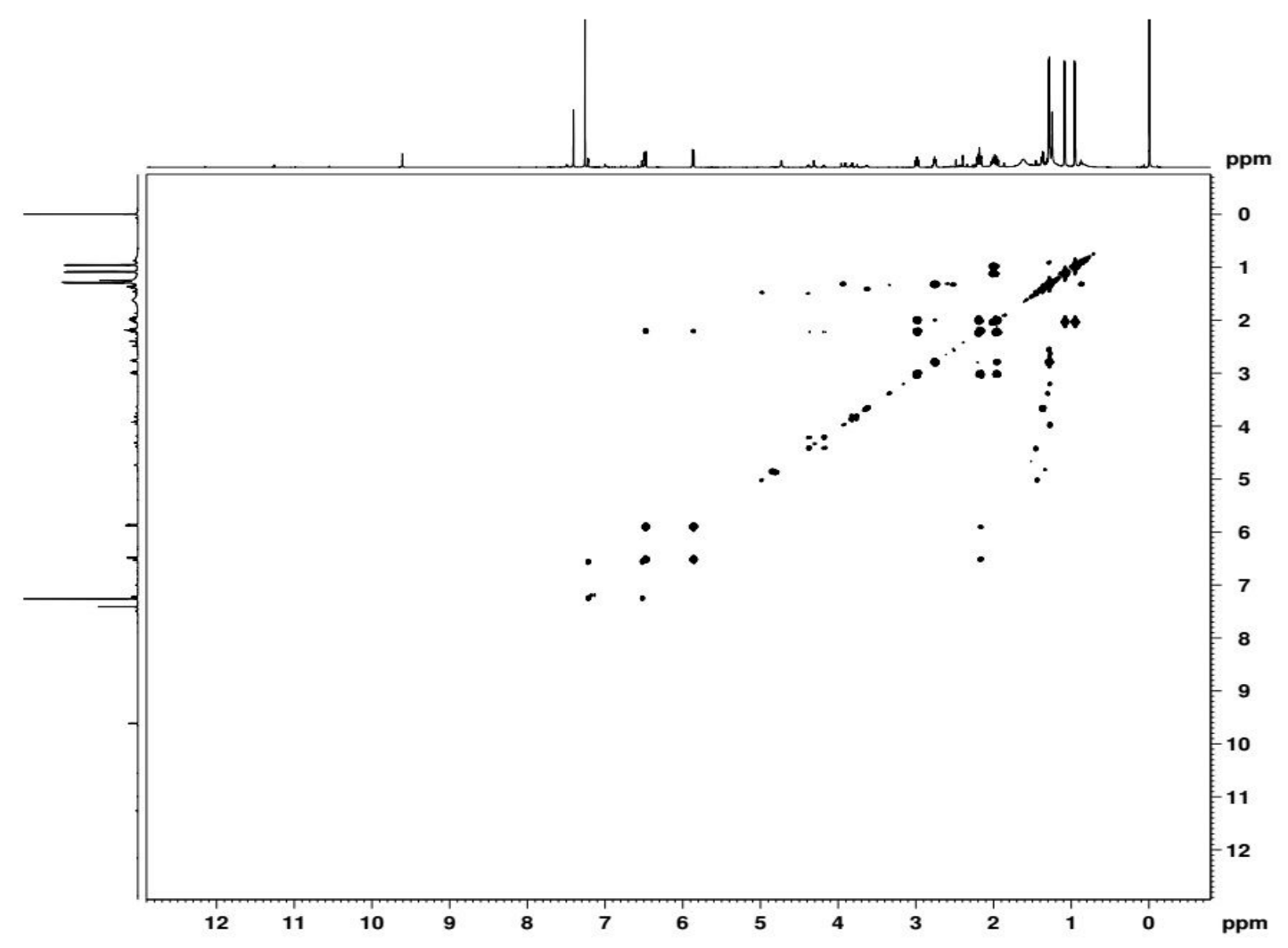

Figure S44. ${ }^{1} \mathrm{H}-{ }^{1} \mathrm{H}$ COSY spectrum of the new compound 6

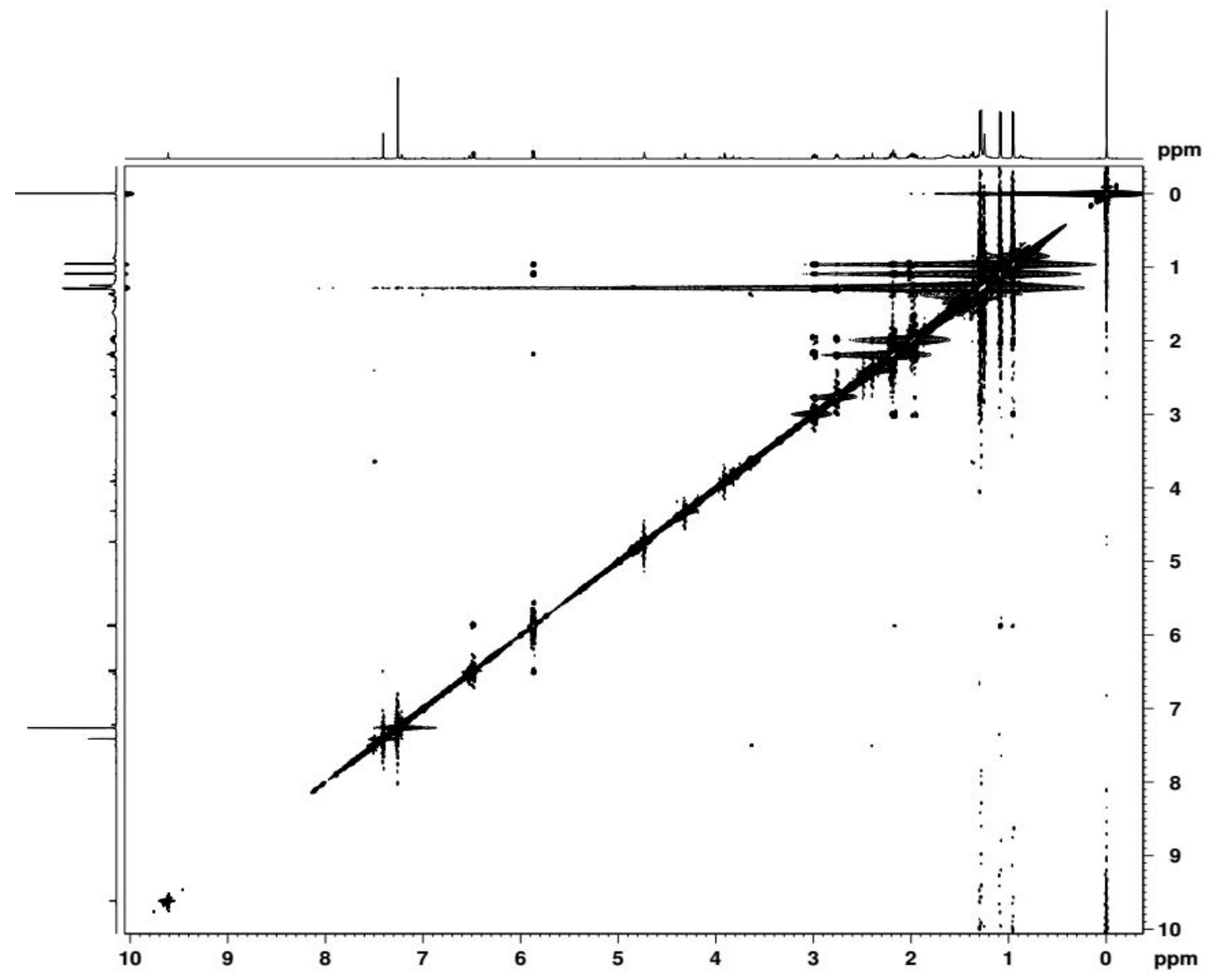

Figure S45. ROESY spectrum of the new compound 6 


\section{HJXC-29-3}

HJXC-29-3 413 (8.031) Cm (405:419)

100

$\%$

Figure S46. Positive ion HRESIMS of 6

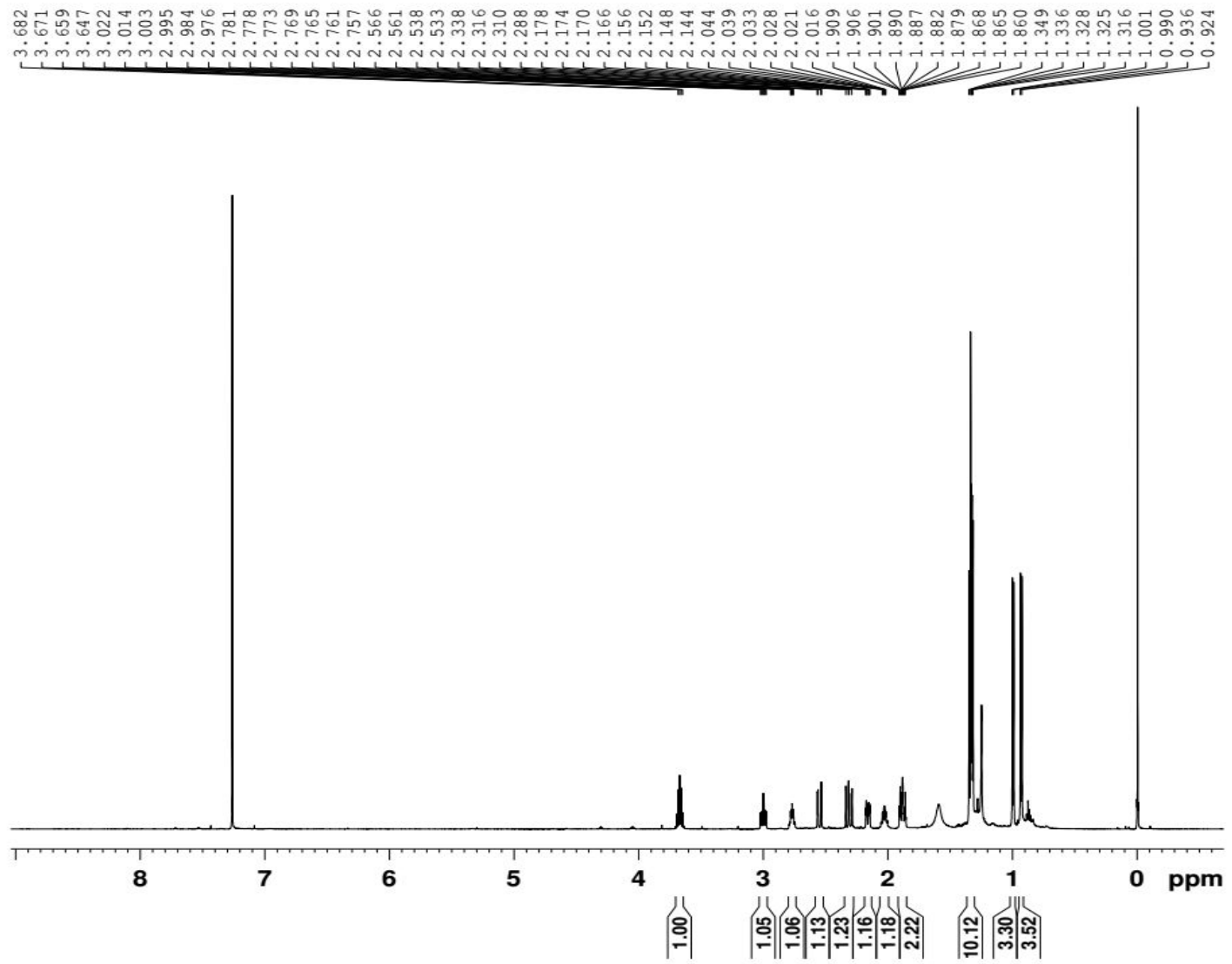

Figure S47. ${ }^{1} \mathrm{H} \mathrm{NMR}\left(600 \mathrm{MHz}, \mathrm{CDCl}_{3}\right)$ spectrum of the new compound 7 


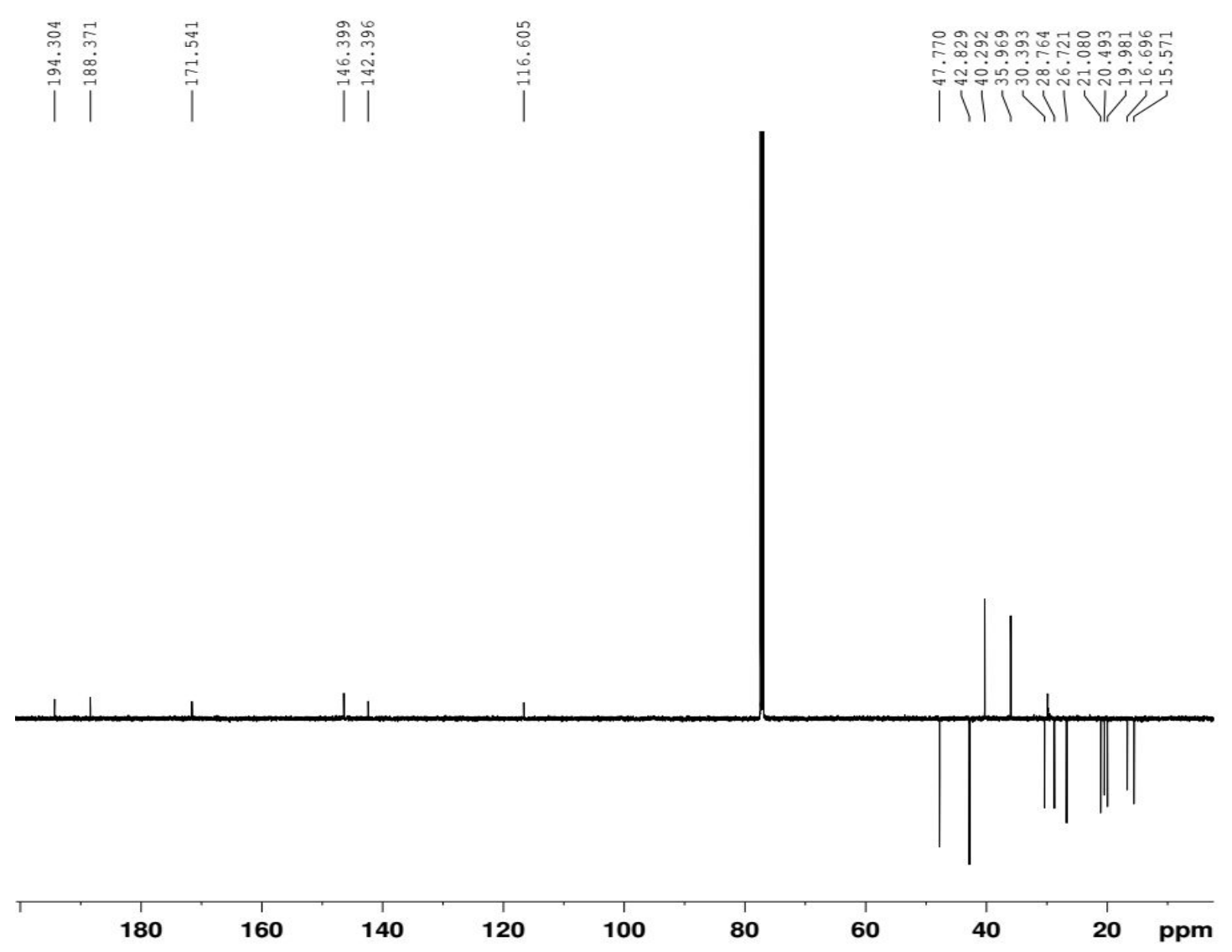

Figure $\mathrm{S} 48 .{ }^{13} \mathrm{C}$ APT $\left(150 \mathrm{MHz}, \mathrm{CDCl}_{3}\right)$ spectrum of the new compound 7

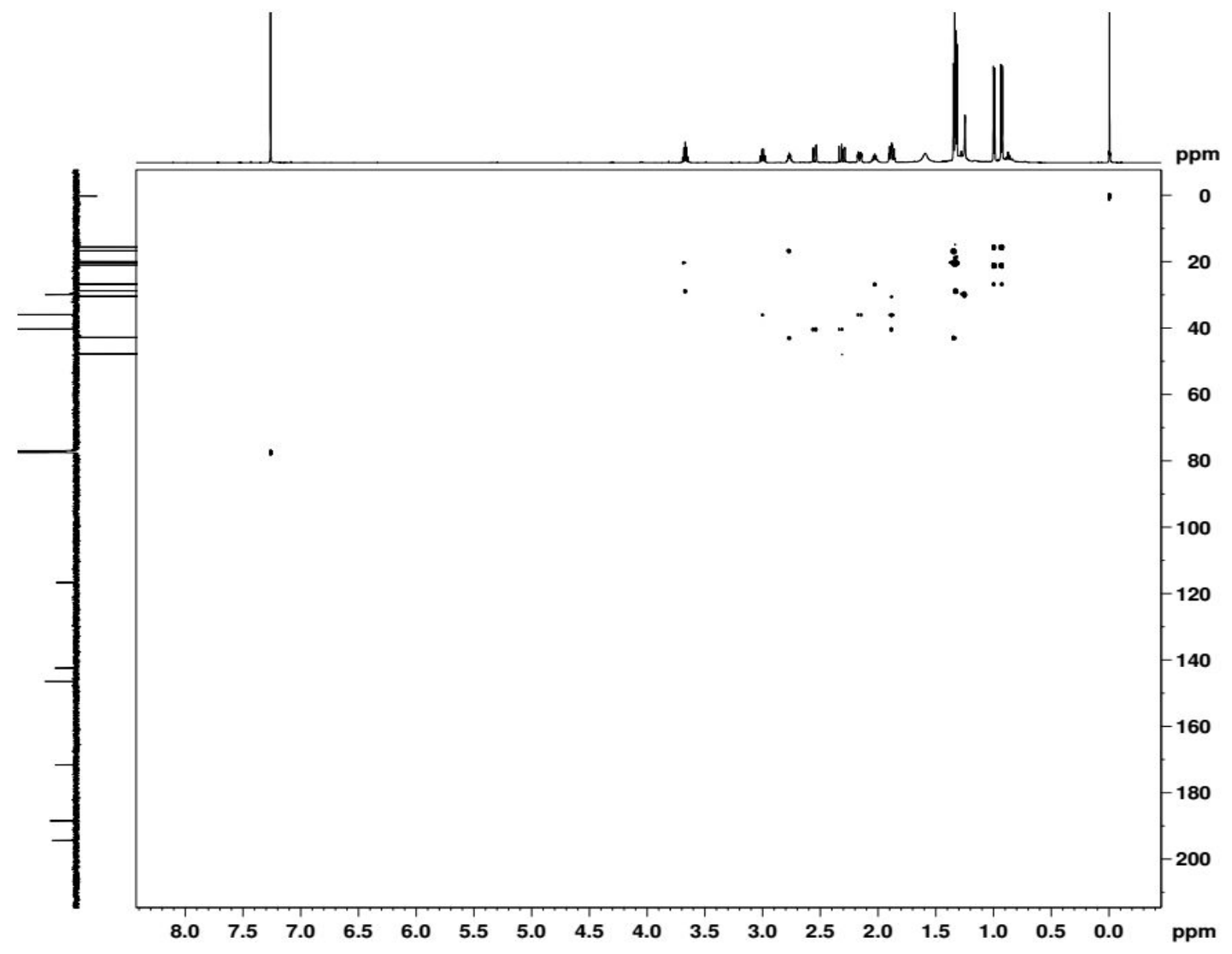

Figure S49. HSQC spectrum of the new compound 7 


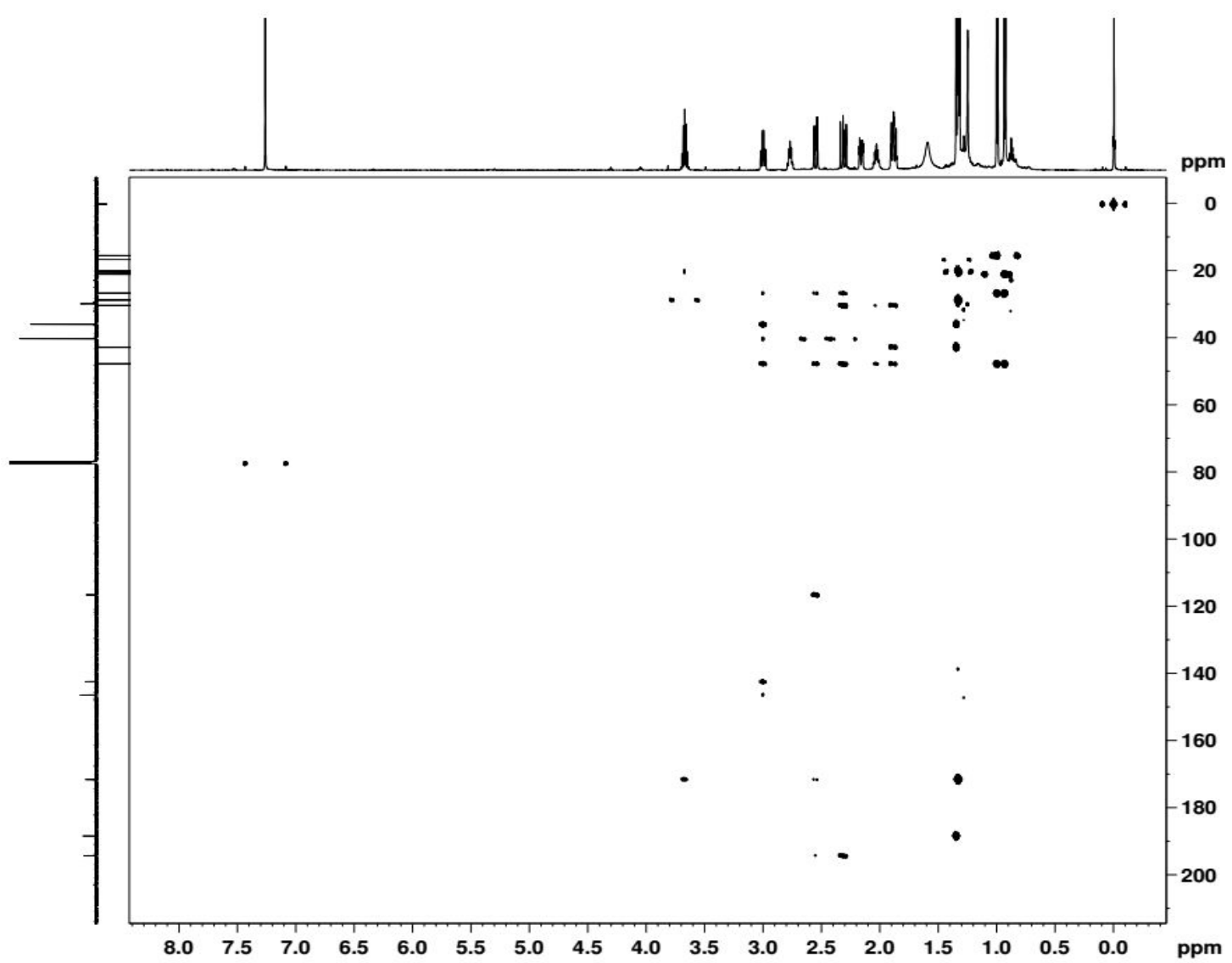

Figure S50. HMBC spectrum of the new compound 7

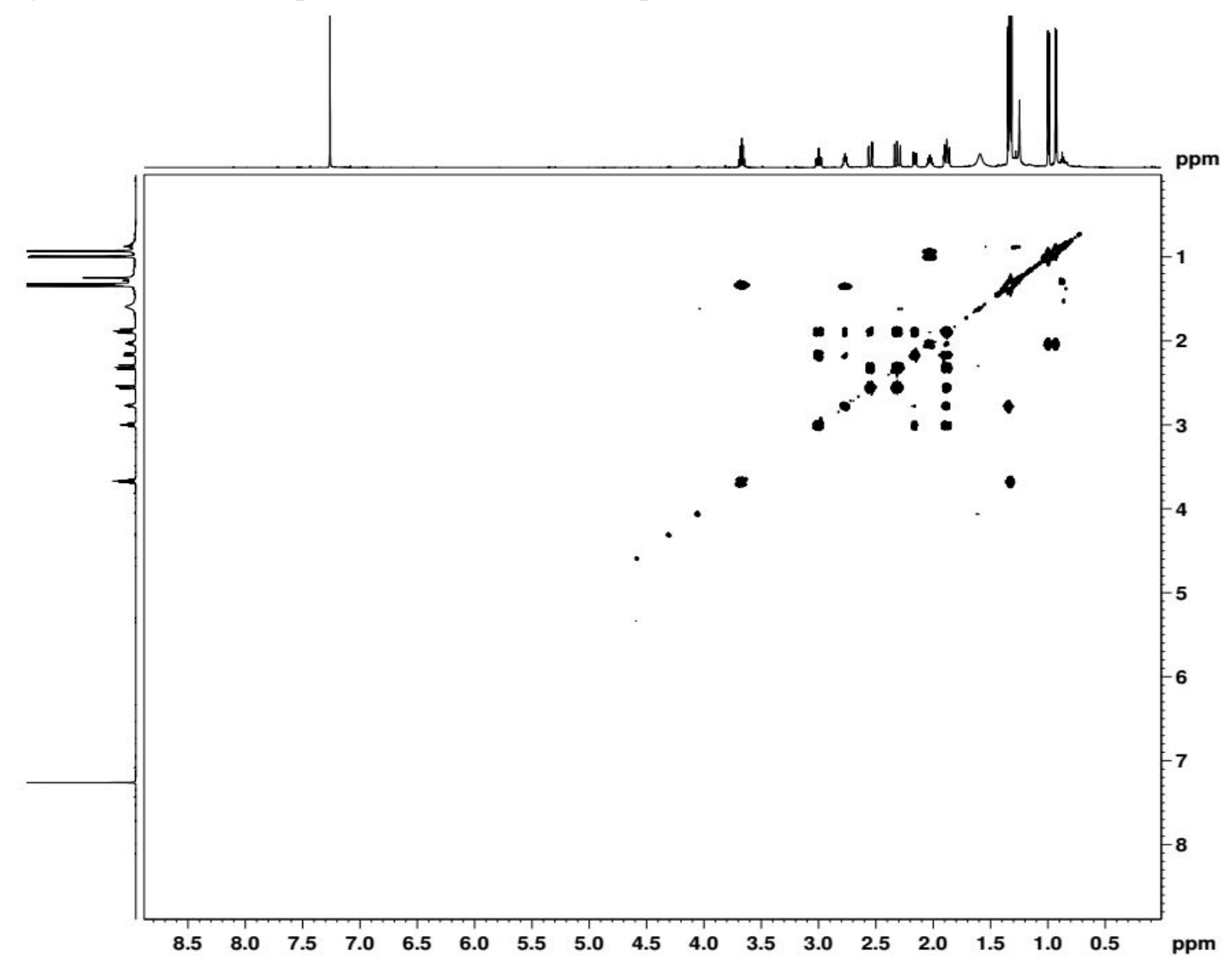

Figure S51. ${ }^{1} \mathrm{H}-{ }^{1} \mathrm{H}$ COSY spectrum of the new compound 7 


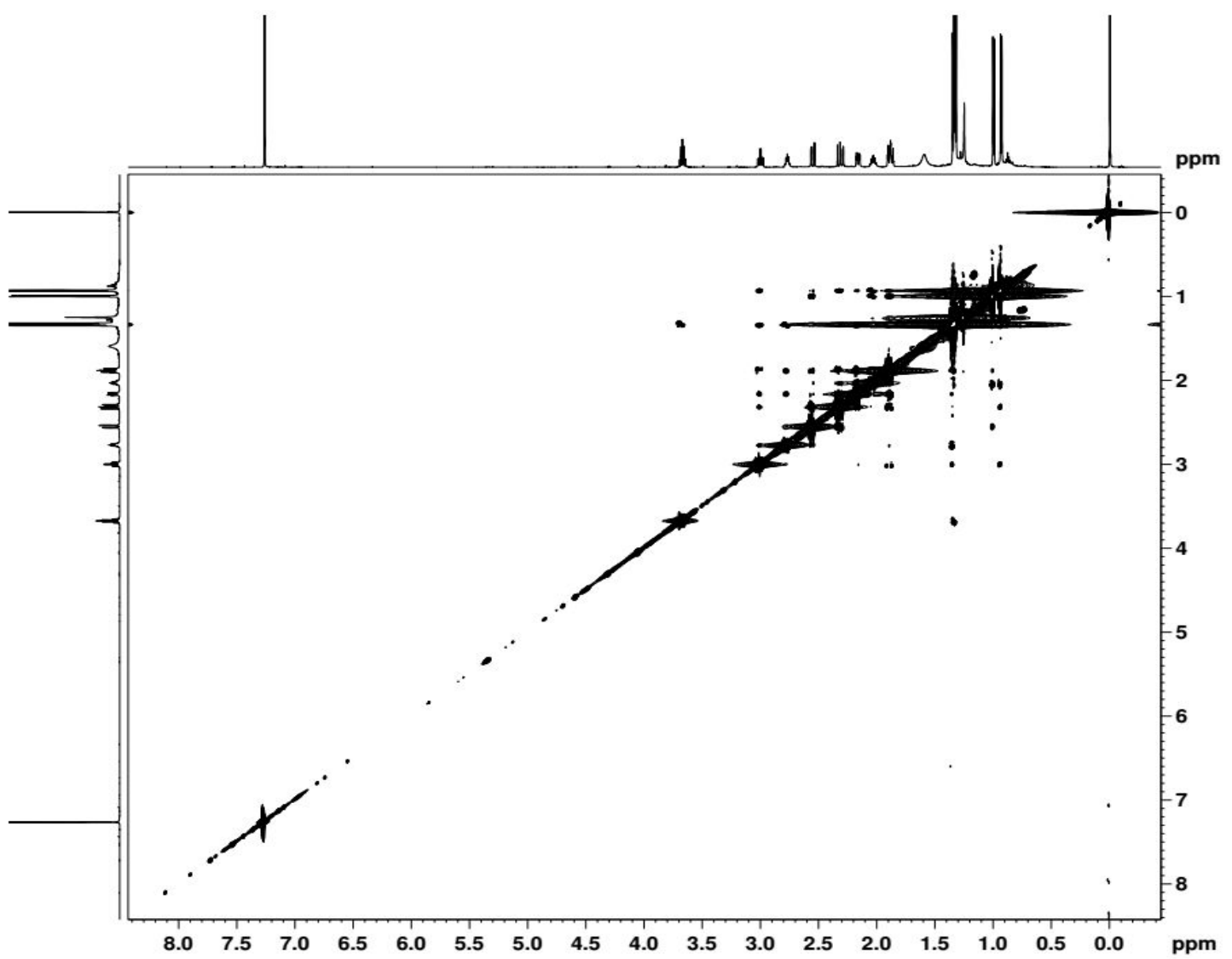

Figure S52. ROESY spectrum of the new compound 7

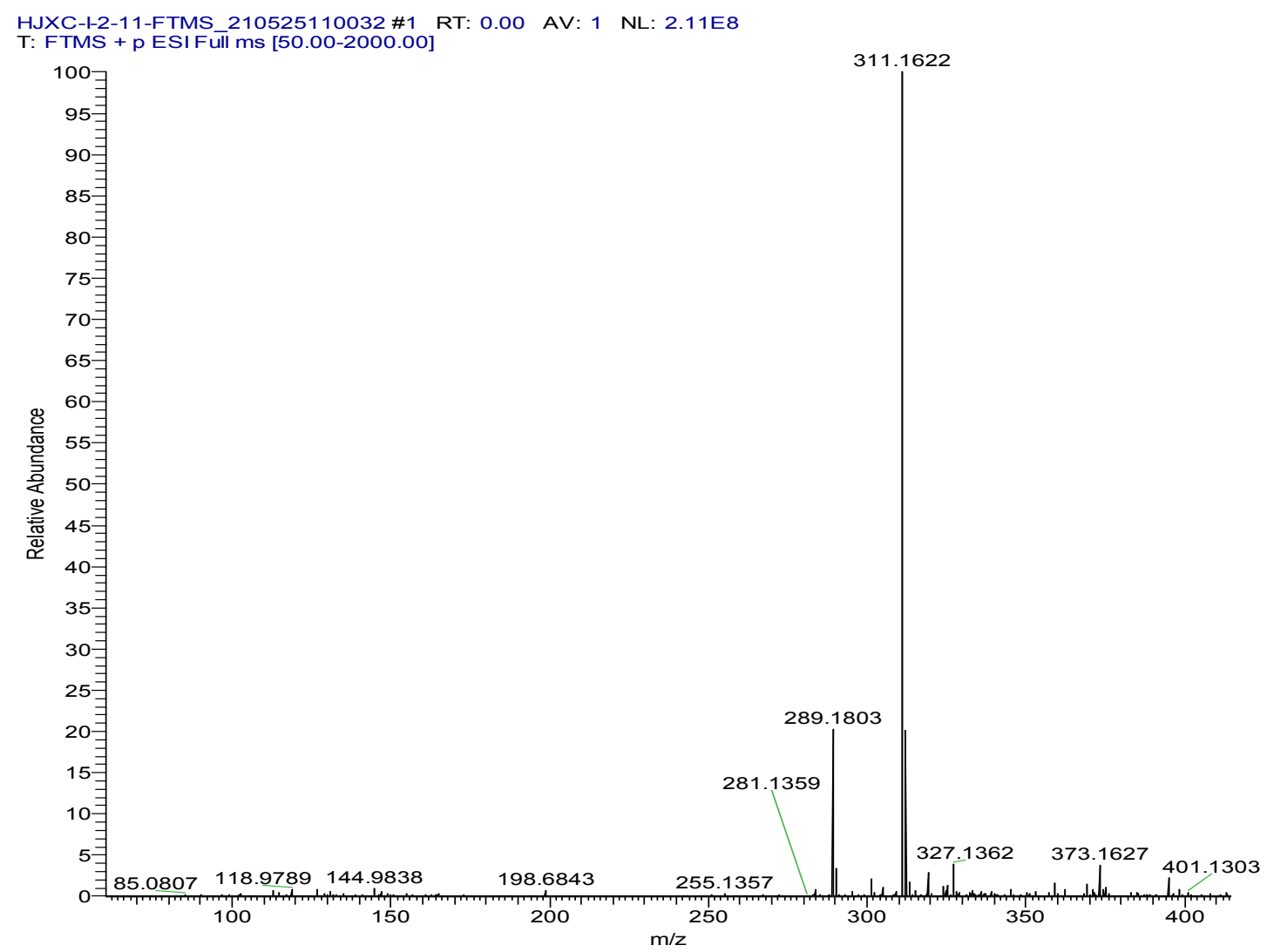

Figure S53. Positive ion HRESIMS of 7 


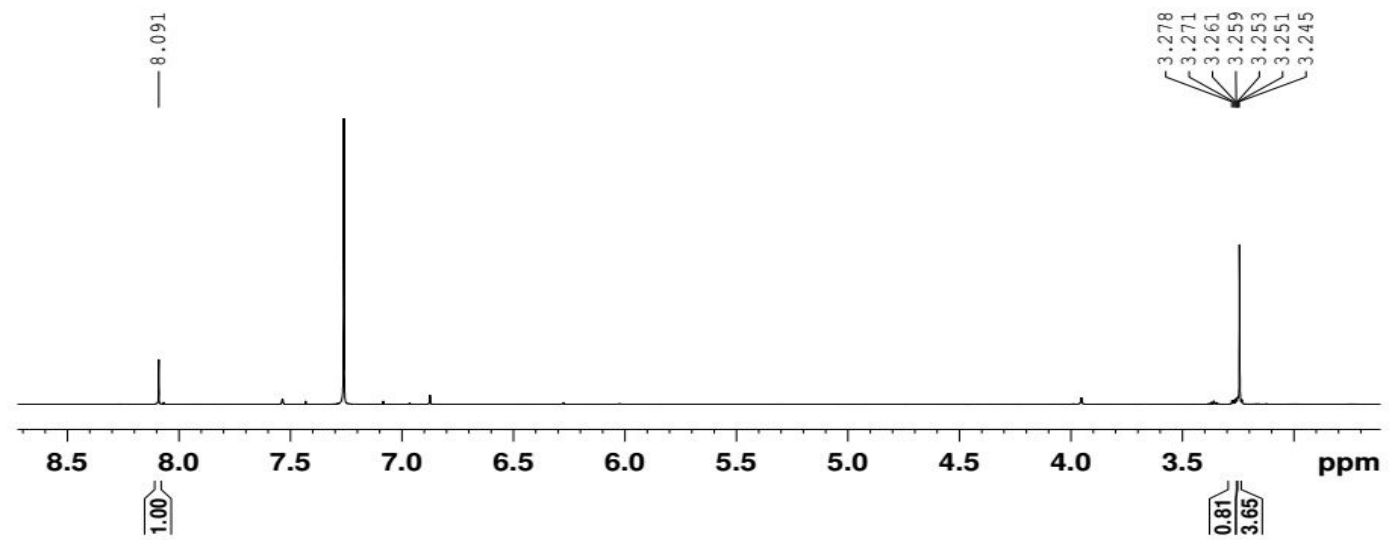

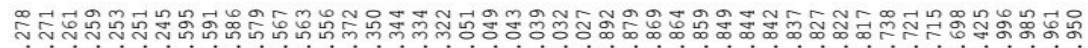

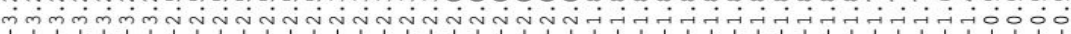

$\longrightarrow$ m

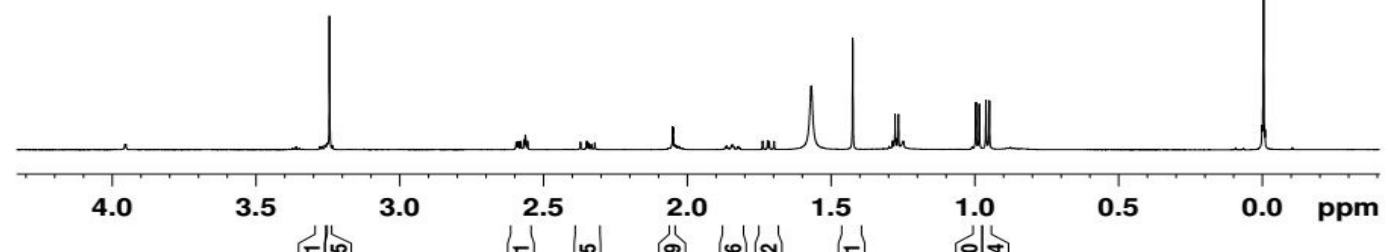

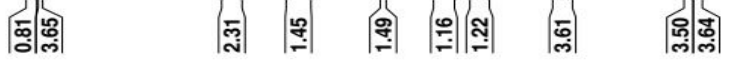

Figure S54. ${ }^{1} \mathrm{H}$ NMR $\left(600 \mathrm{MHz}, \mathrm{CDCl}_{3}\right)$ spectrum of the new compound 8

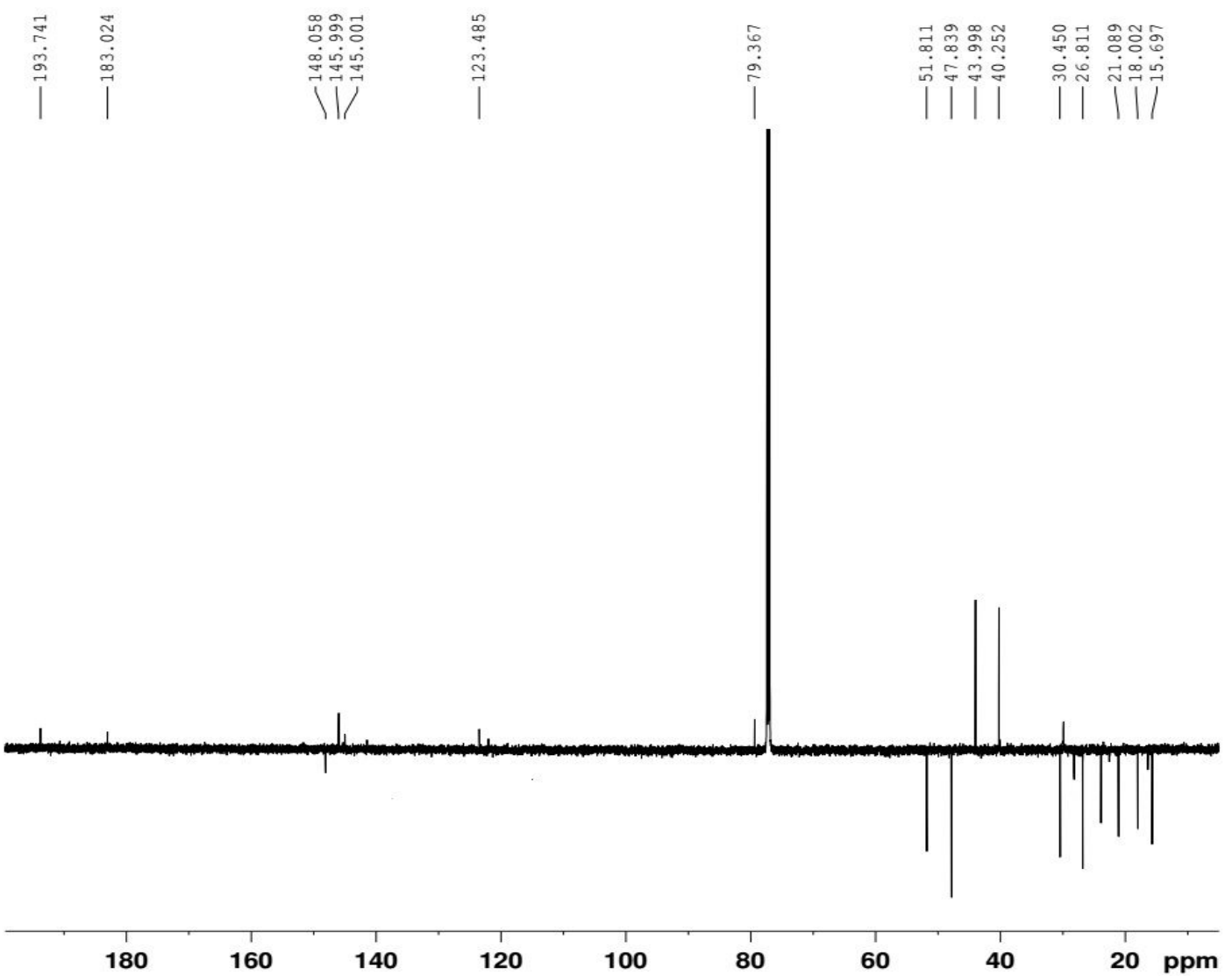

Figure S55. ${ }^{13} \mathrm{C}$ APT $\left(150 \mathrm{MHz}, \mathrm{CDCl}_{3}\right)$ spectrum of the new compound 8 


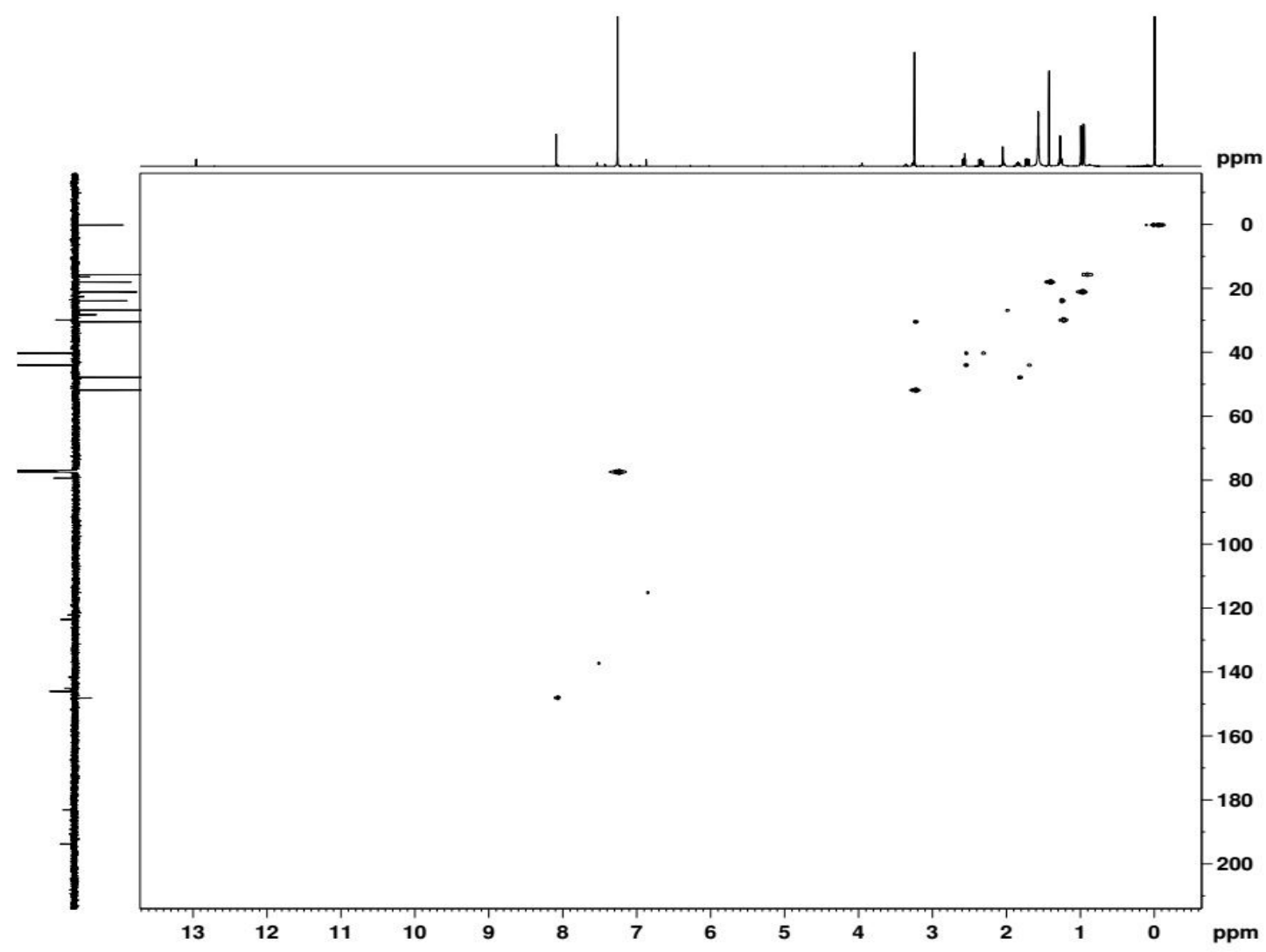

Figure S56. HSQC spectrum of the new compound 8

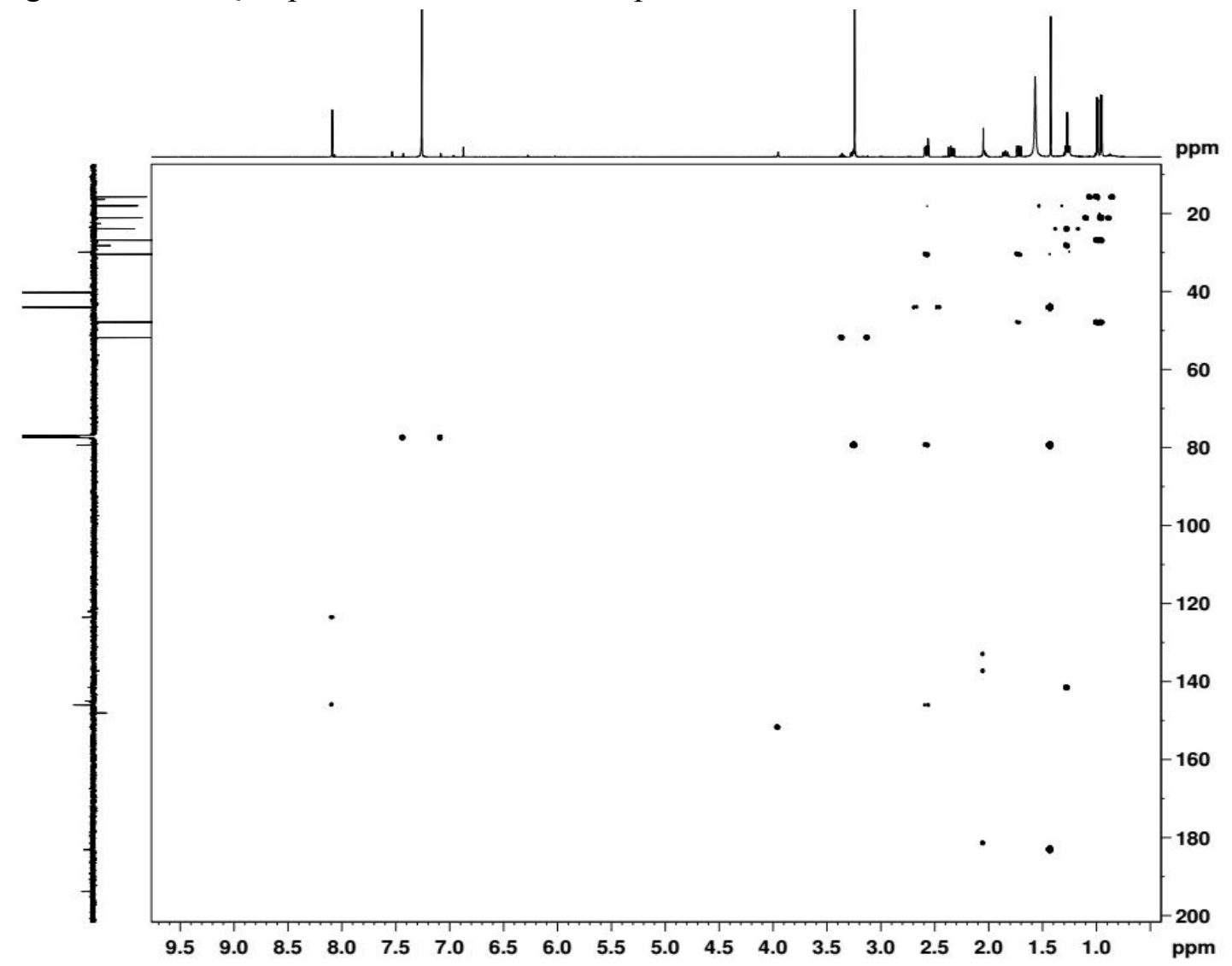

Figure S57. HMBC spectrum of the new compound 8 


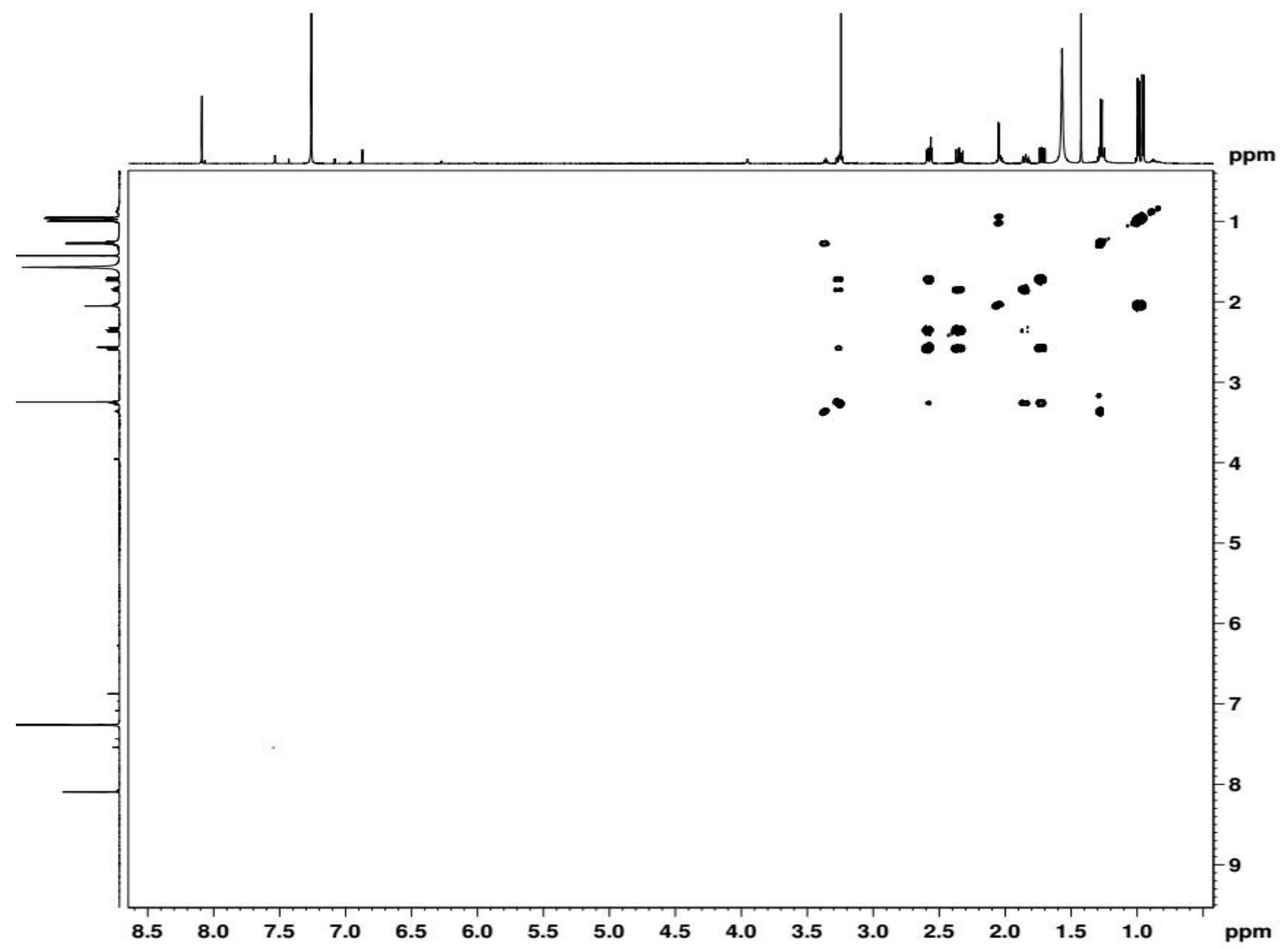

Figure S58. ${ }^{1} \mathrm{H}-{ }^{1} \mathrm{H}$ COSY spectrum of the new compound 8

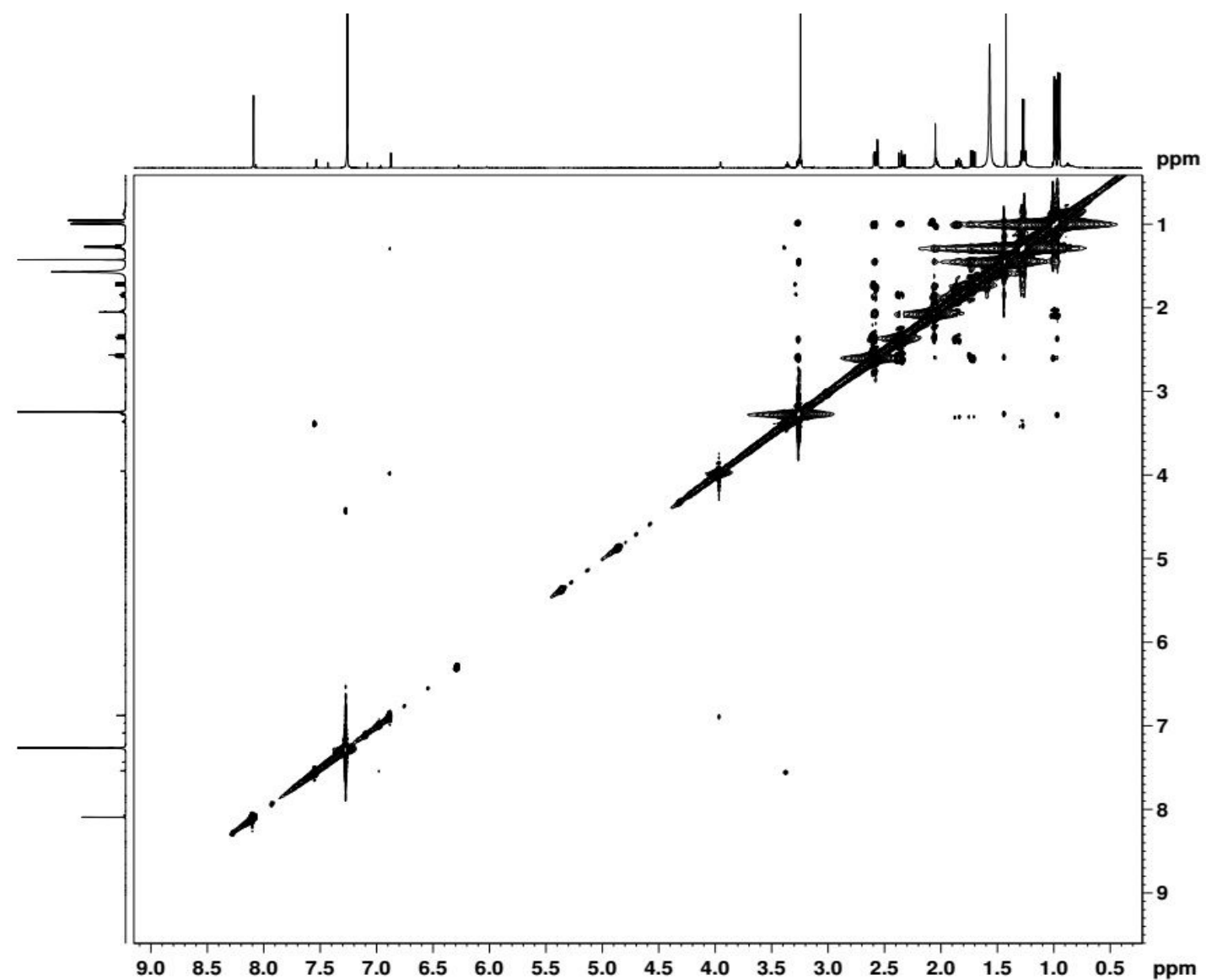

Figure S59. ROESY spectrum of the new compound 8 


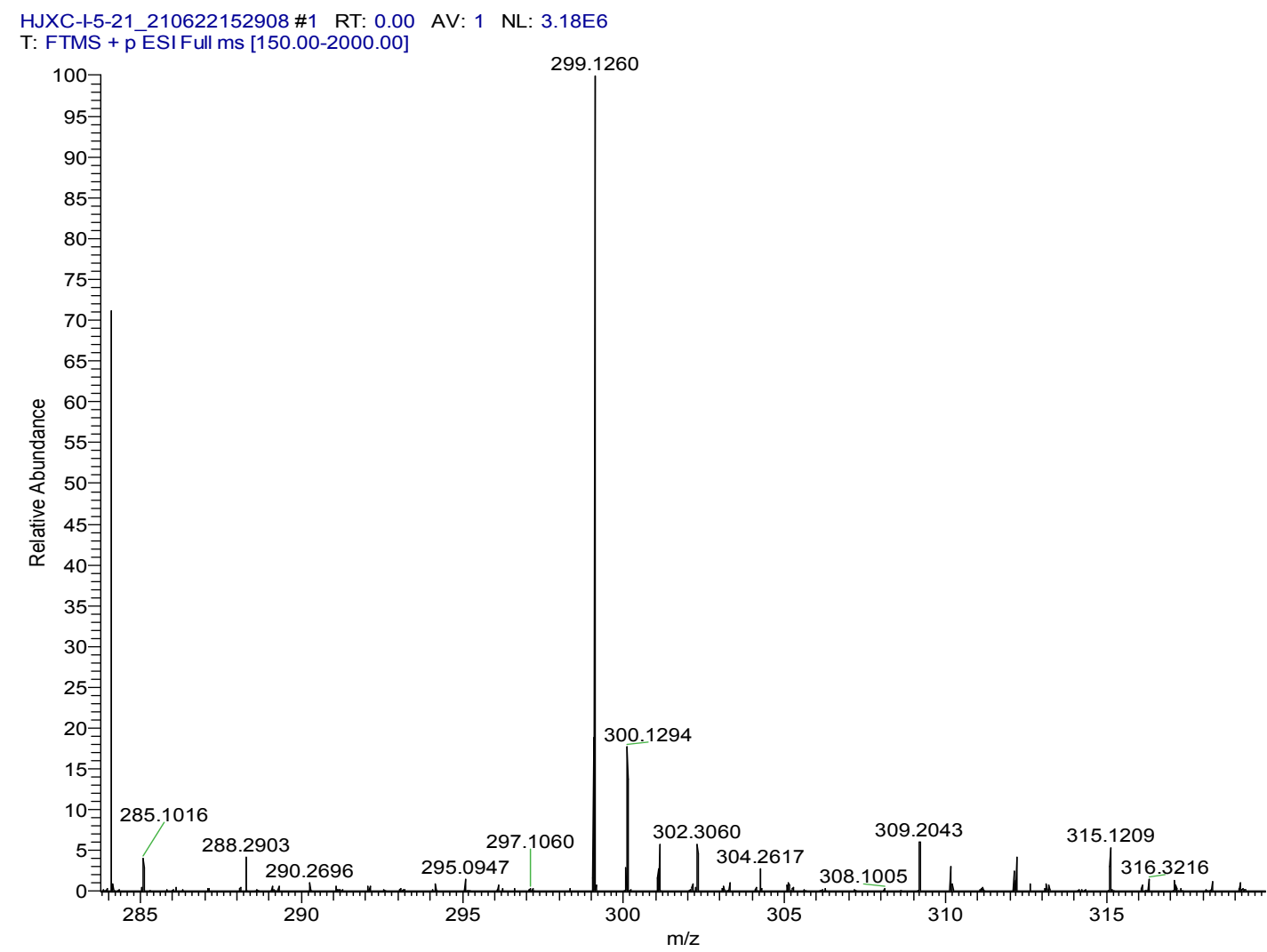

Figure S60. Positive ion HRESIMS of 8

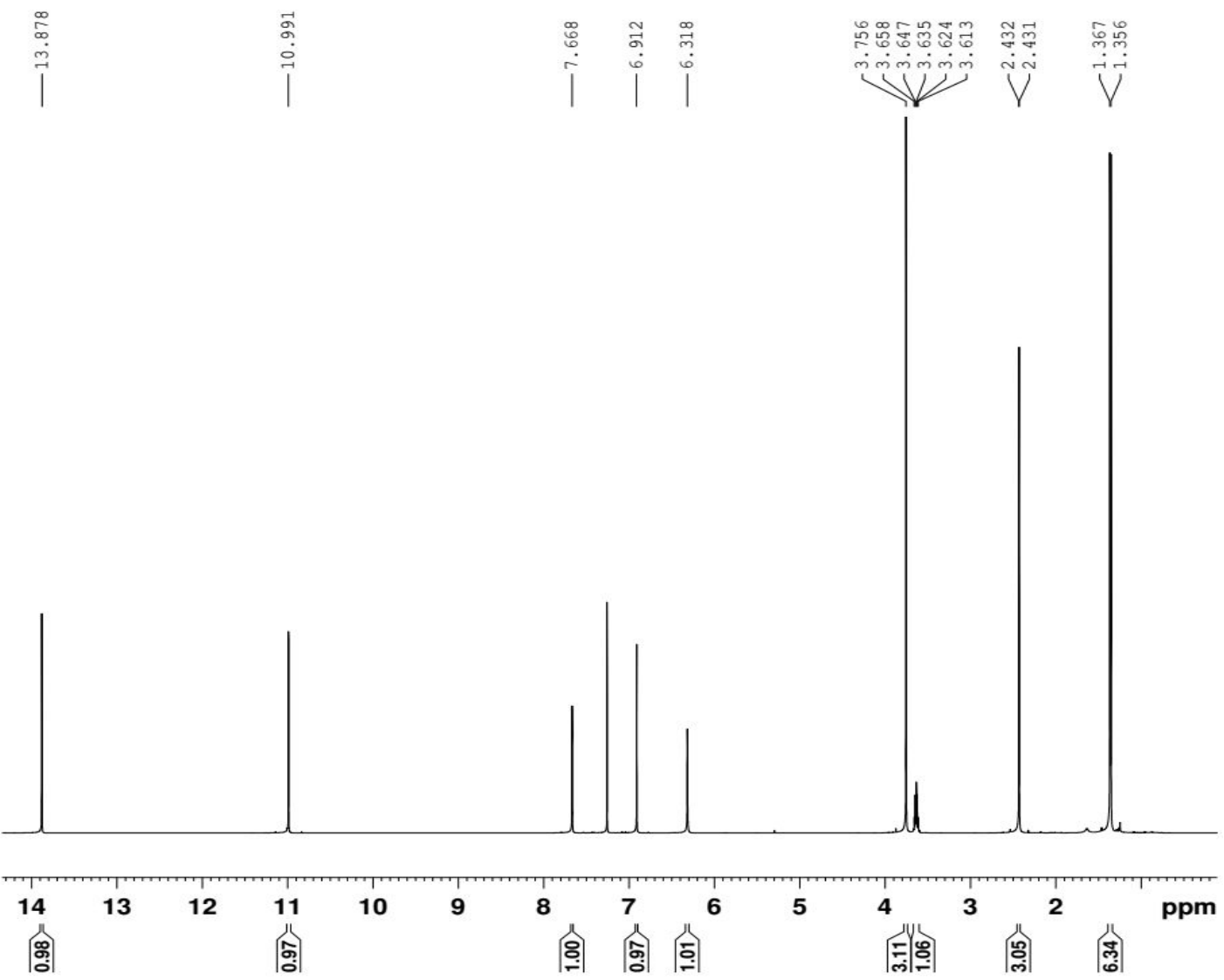

Figure S61. ${ }^{1} \mathrm{H}$ NMR $\left(600 \mathrm{MHz}, \mathrm{CDCl}_{3}\right)$ spectrum of the new compound 9 


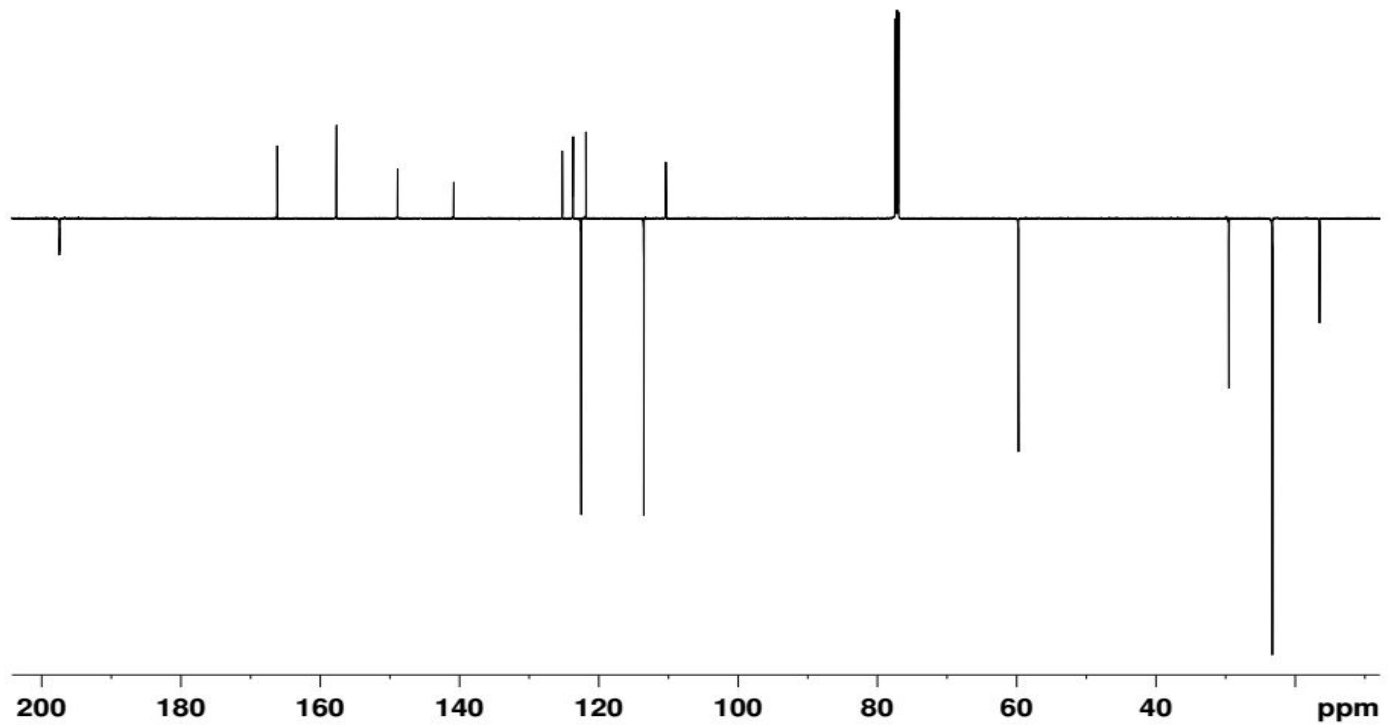

Figure S62. ${ }^{13} \mathrm{C}$ APT $\left(150 \mathrm{MHz}, \mathrm{CDCl}_{3}\right)$ spectrum of the new compound 9

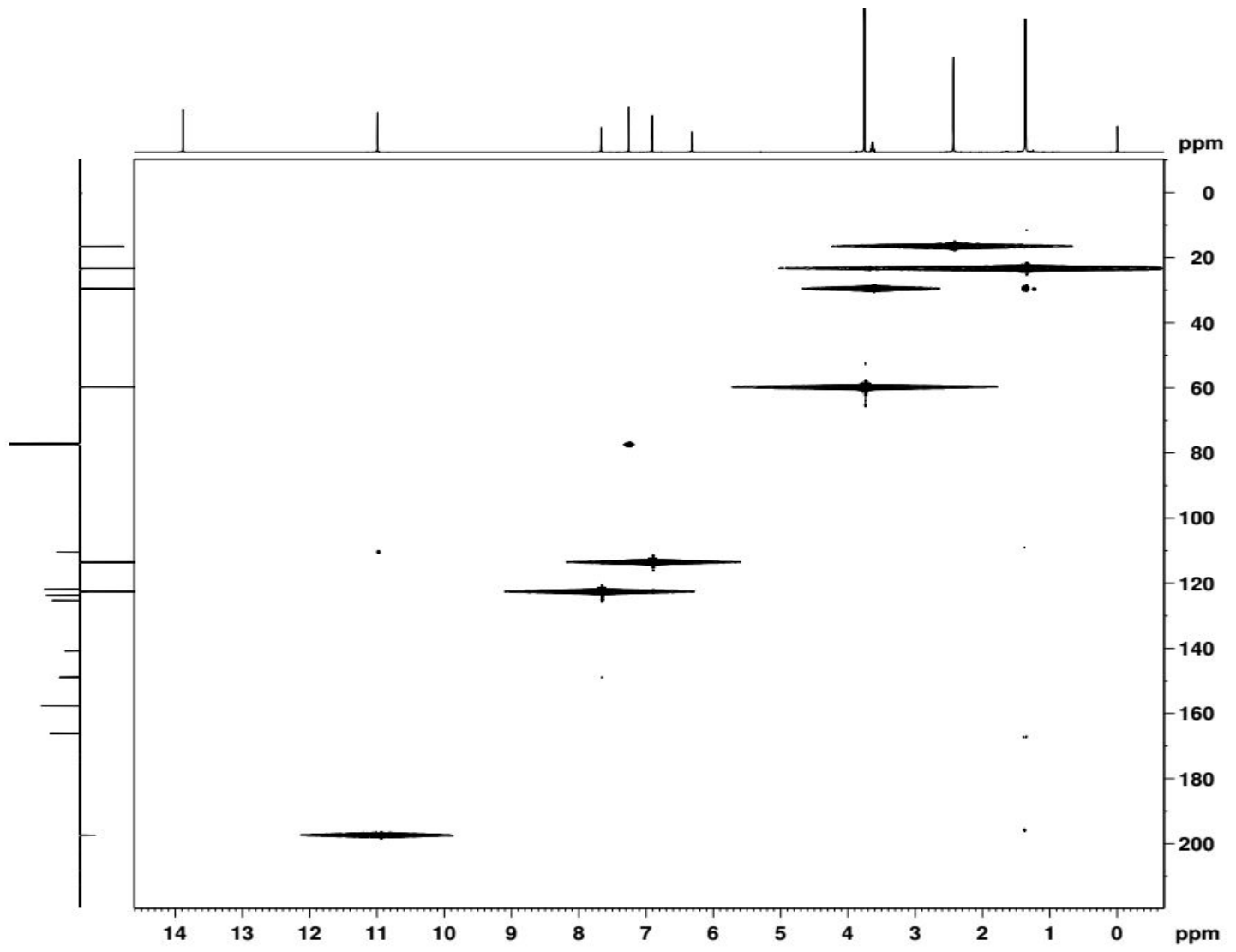

Figure S63. HSQC spectrum of the new compound 9 


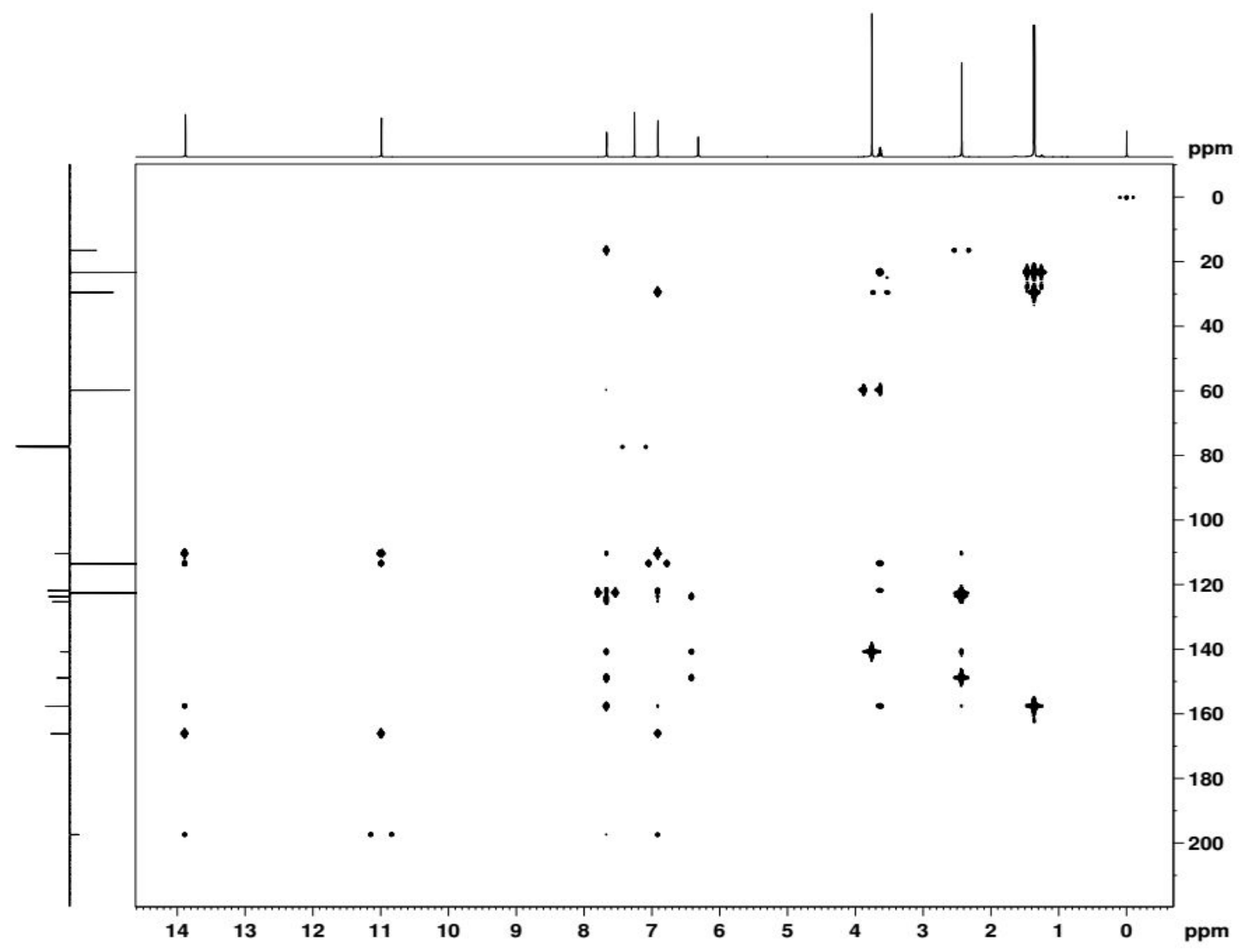

Figure S64. HMBC spectrum of the new compound 9

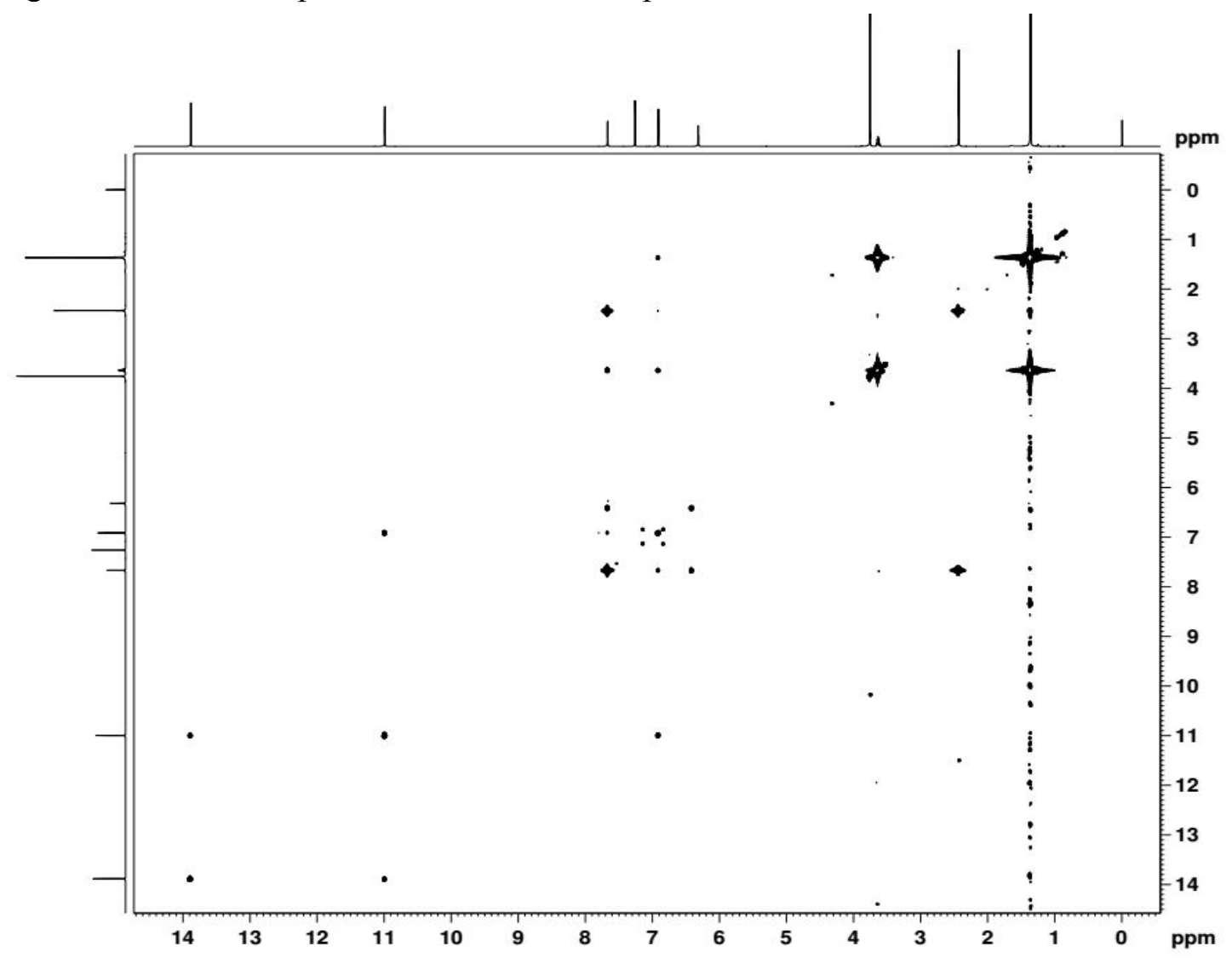

Figure S65. ${ }^{1} \mathrm{H}-{ }^{1} \mathrm{H}$ COSY spectrum of the new compound 9 


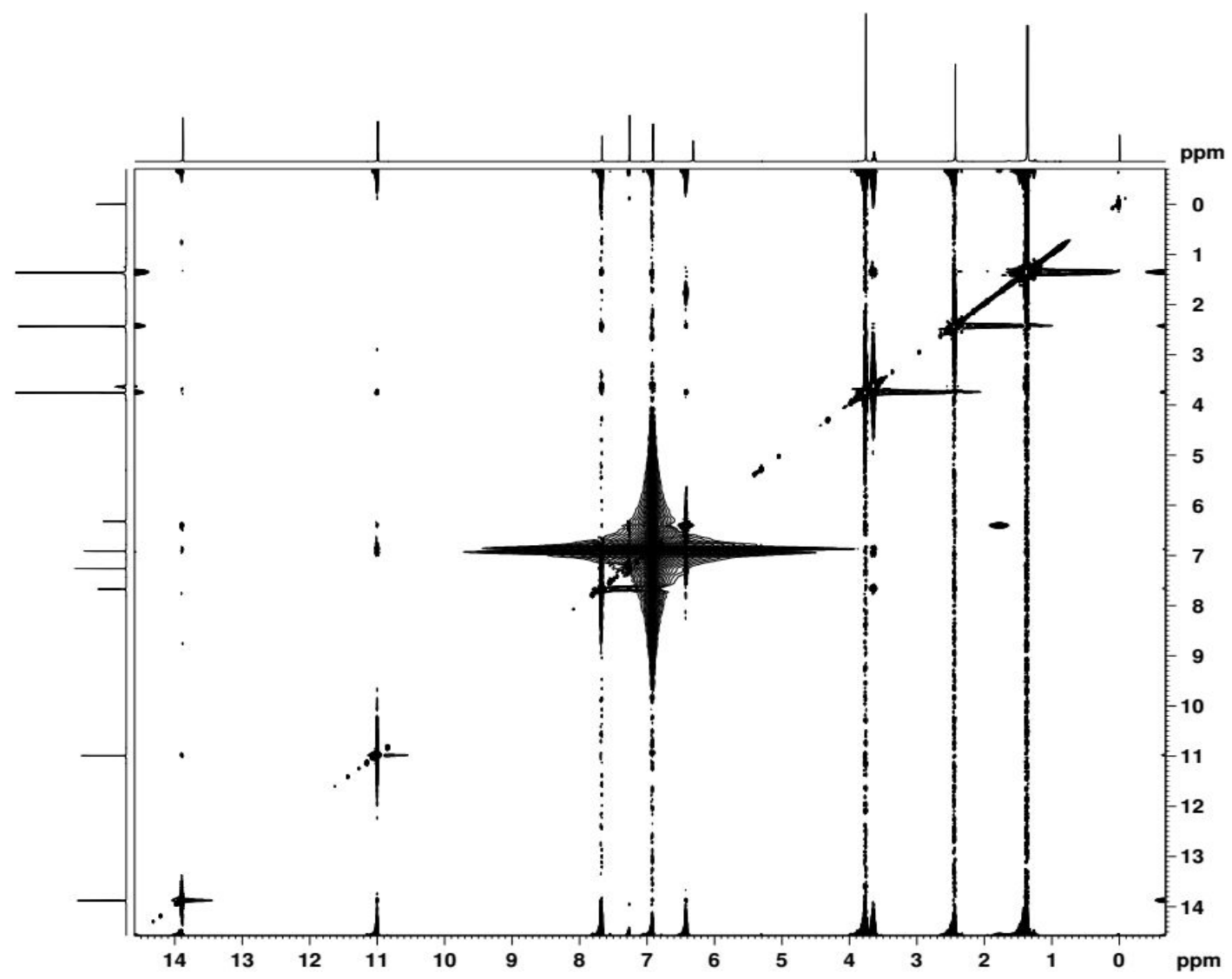

Figure S66. ROESY spectrum of the new compound 9

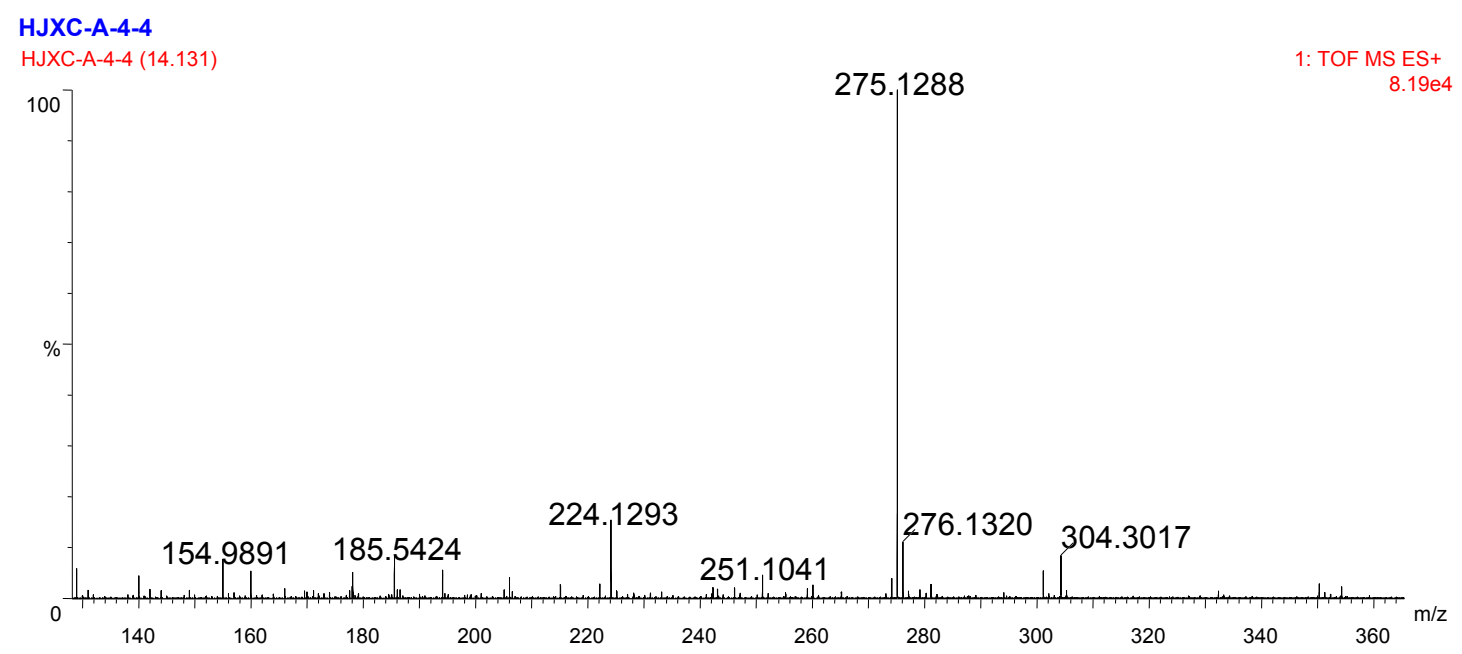

Figure S67. Positive ion HRESIMS of 9 


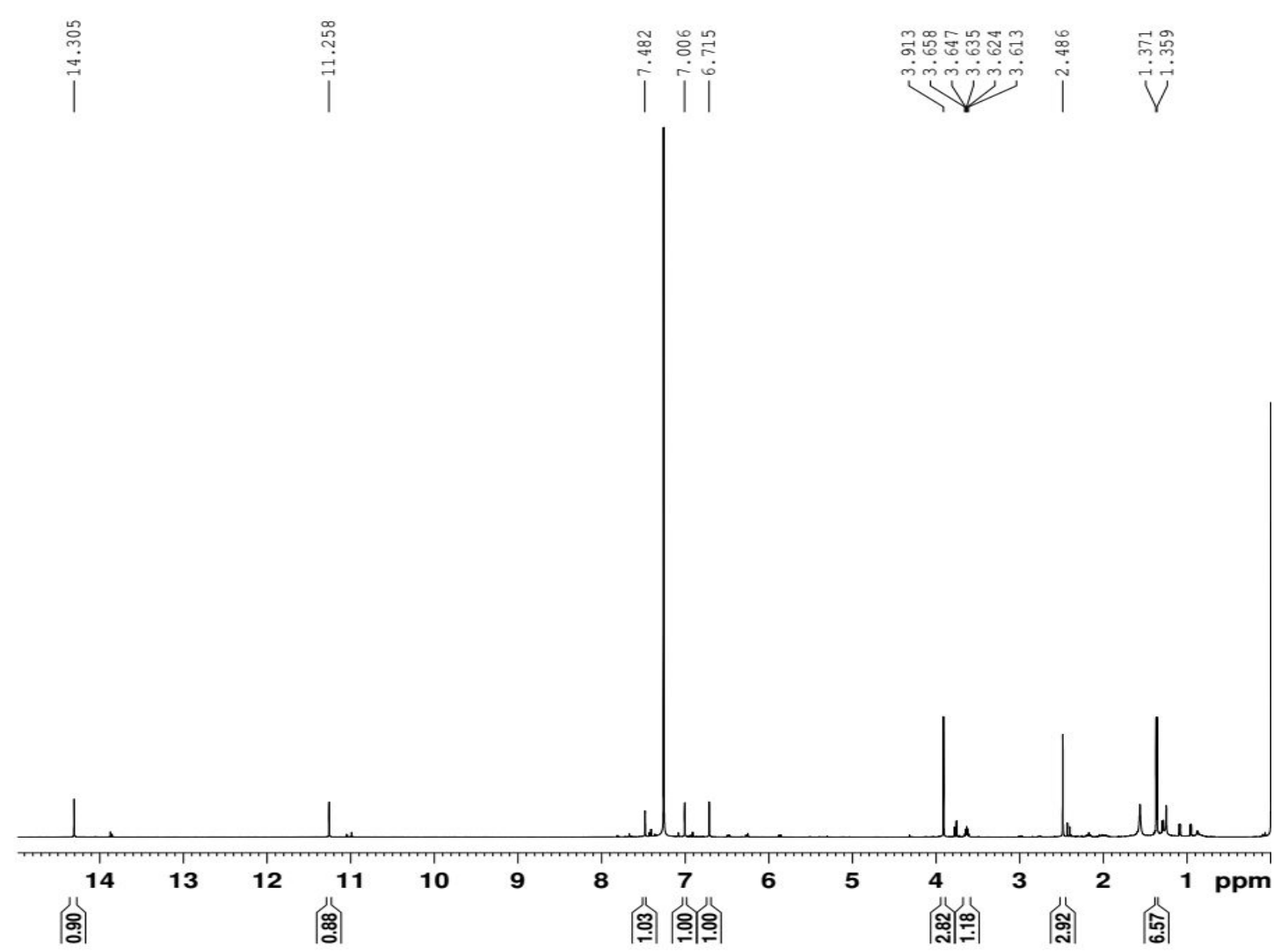

Figure S68. ${ }^{1} \mathrm{H}$ NMR $\left(600 \mathrm{MHz}, \mathrm{CDCl}_{3}\right)$ spectrum of the new compound 10

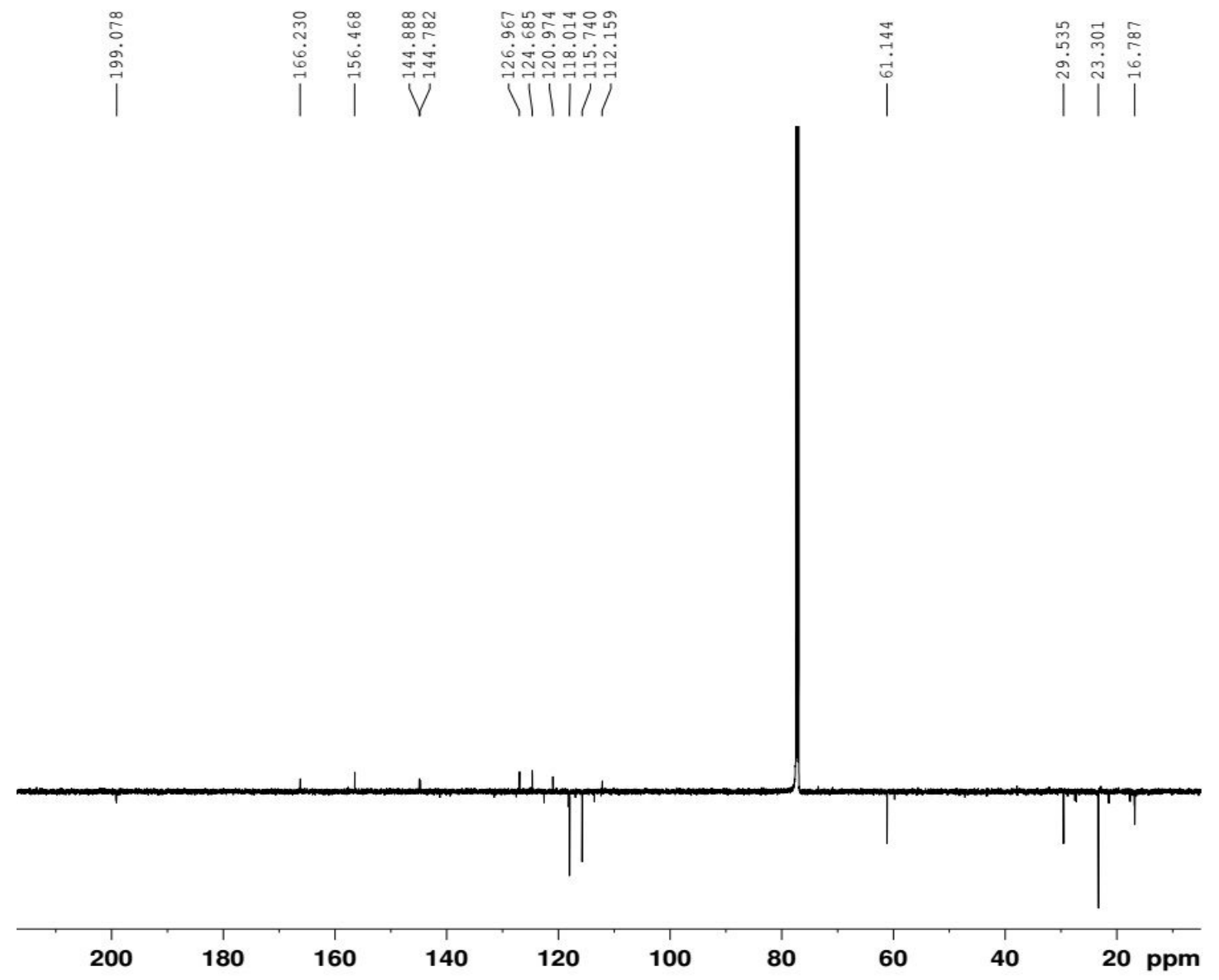

Figure $\mathrm{S} 69 .{ }^{13} \mathrm{C}$ APT $\left(150 \mathrm{MHz}, \mathrm{CDCl}_{3}\right)$ spectrum of the new compound $\mathbf{1 0}$ 


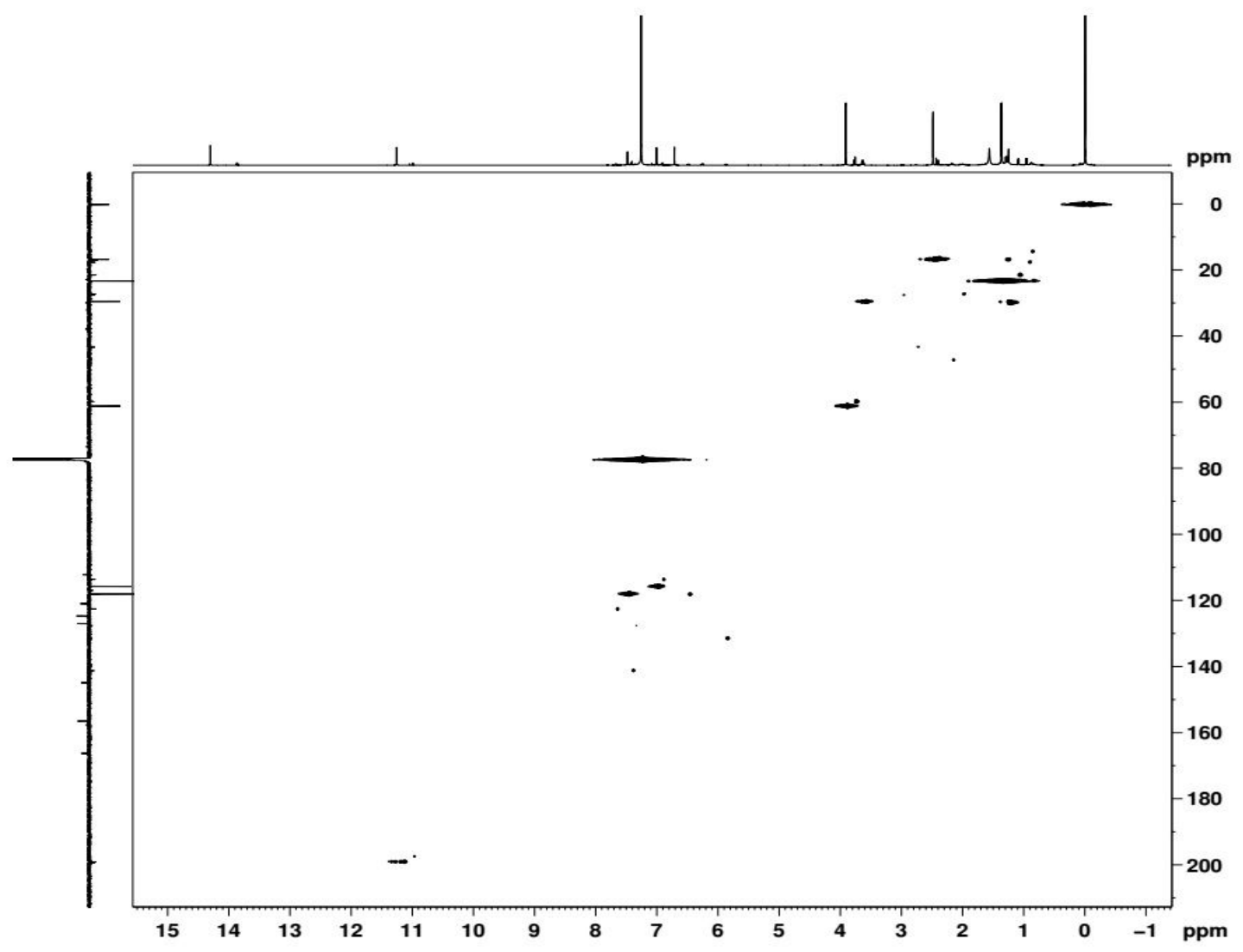

Figure S70. HSQC spectrum of the new compound $\mathbf{1 0}$

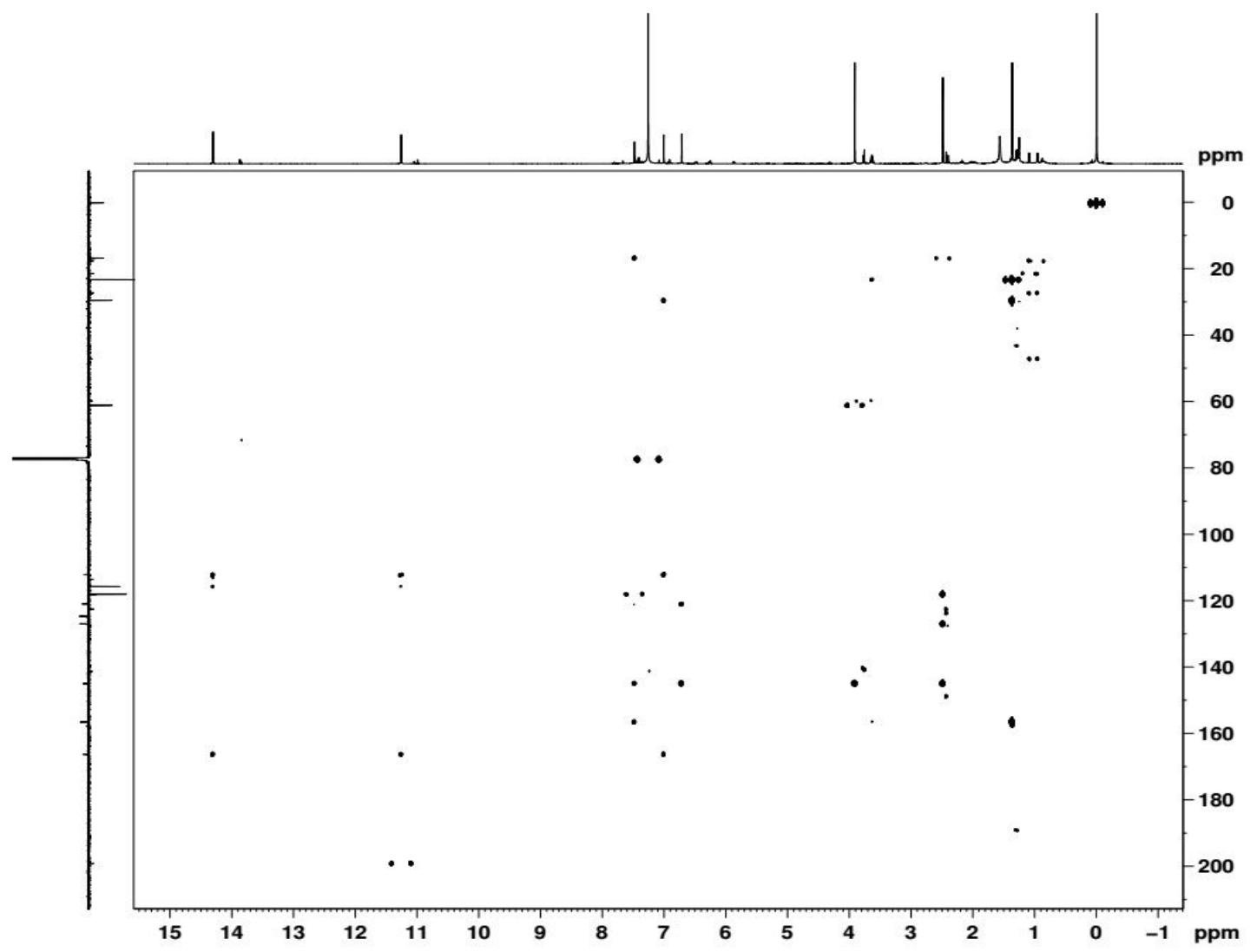

Figure S71. HMBC spectrum of the new compound $\mathbf{1 0}$ 


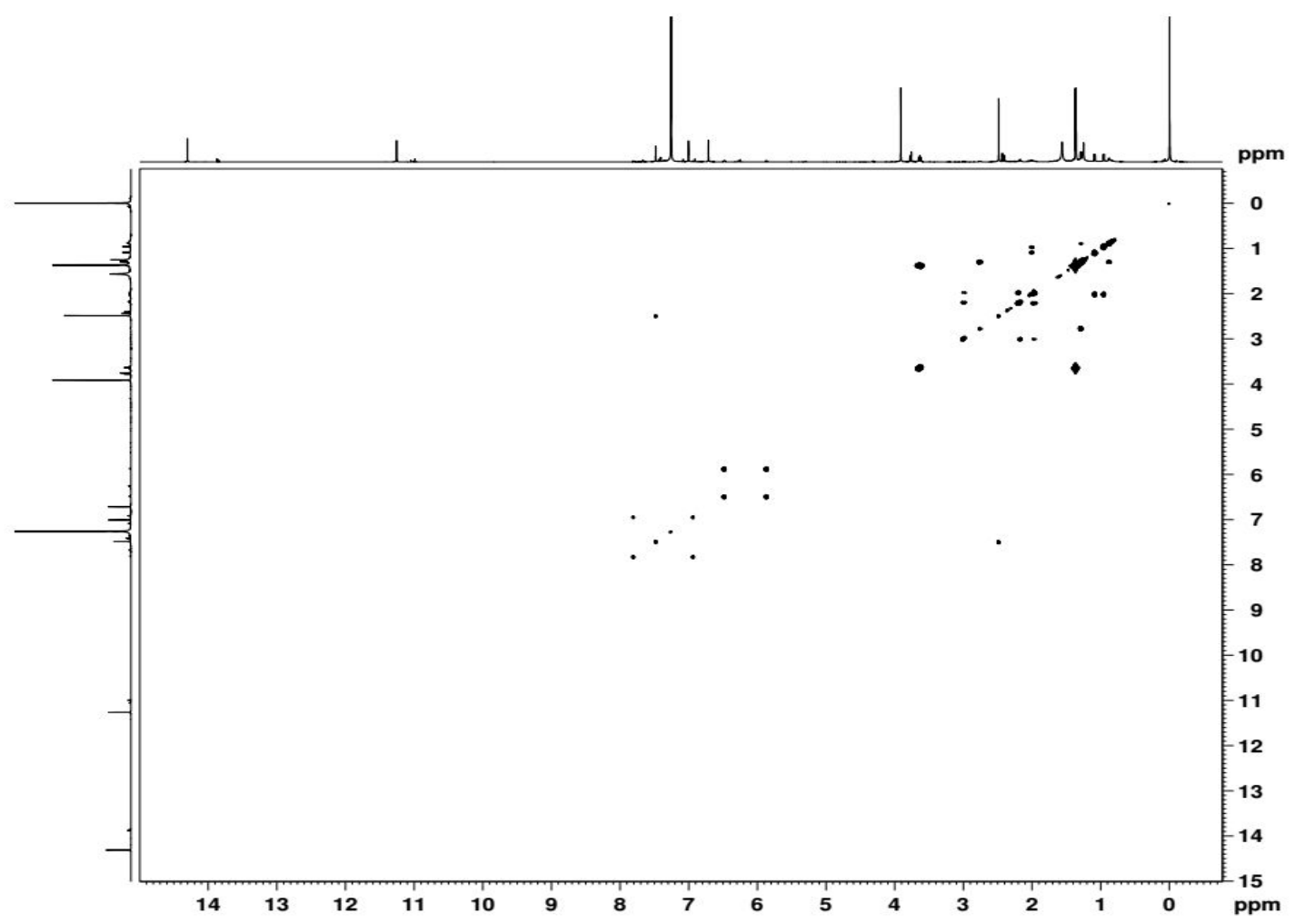

Figure S72. ${ }^{1} \mathrm{H}-{ }^{1} \mathrm{H}$ COSY spectrum of the new compound $\mathbf{1 0}$

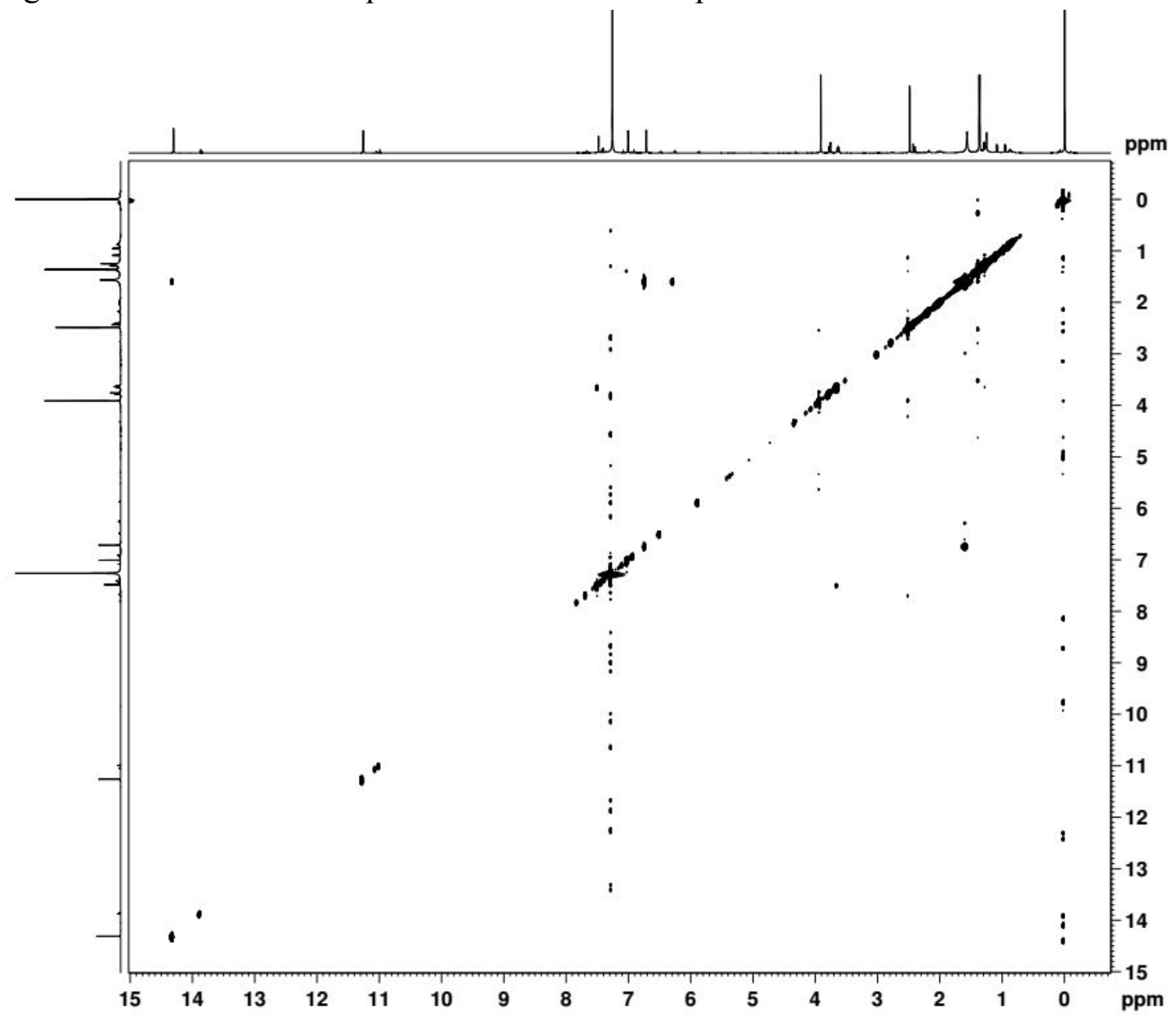

Figure S73. NOESY spectrum of the new compound $\mathbf{1 0}$ 
A_4_3

20191228_08 537 (6.969)

100

275.1280

1: TOF MS ES+

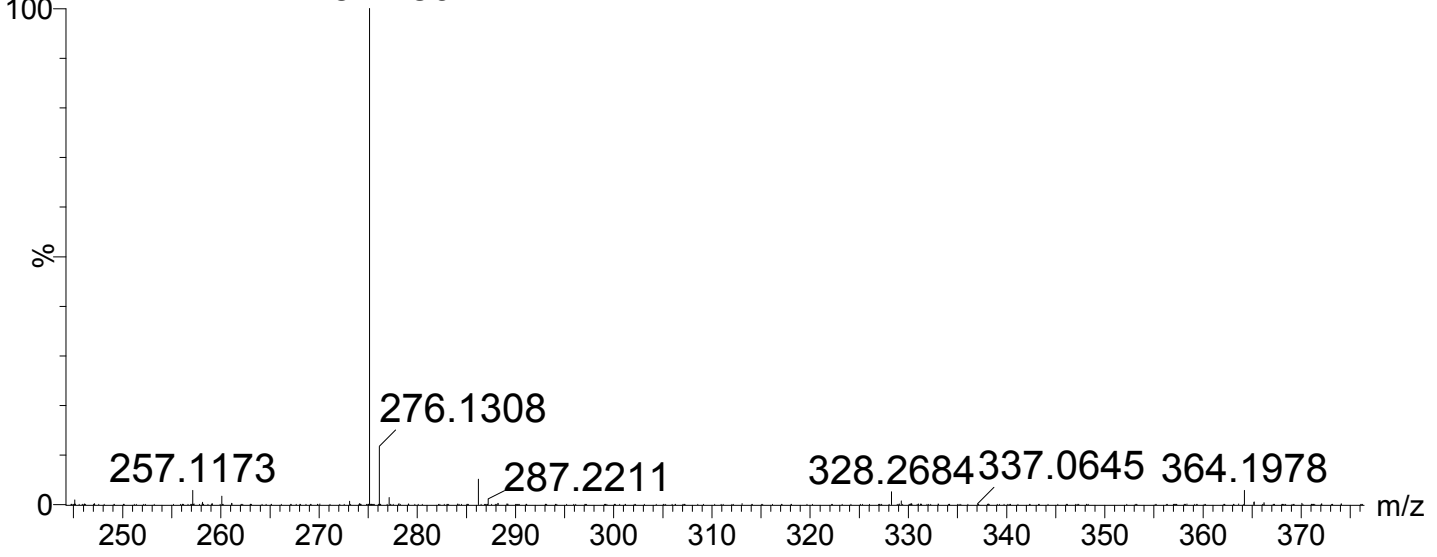

Figure S74. Positive ion HRESIMS of $\mathbf{1 0}$ 